Detailed Design Data Package: Item 3.1a - Film Cooler Pressure Drop Data; Item 3.2a - SBS Packing

RECEIVED APR 011996

Selection; Item 3.2b, 3.2c -

Pressure Drop Data for SBS

OS.TI

Distribution Plate; and Item 3.2e -

SBS Distribution Plate and Liquid

Risers. PHTD Pilot-Scale Melter

Testing System Cost Account

Milestone 1.2.2.04.15A
G. A. Whyatt
L. D. Anderson
J. Evans, II

March 1996

Prepared for the U.S. Department of Energy under Contract DE-AC06-76RLO 1830

Paci

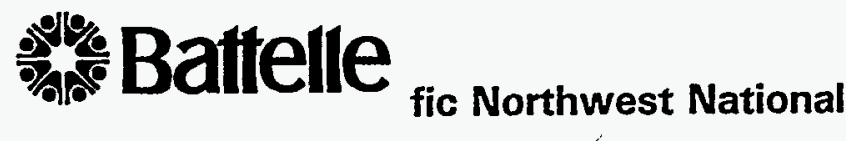

Laboratory

Operated for the U.S. Department of Energy by Battelle Memorial Institute

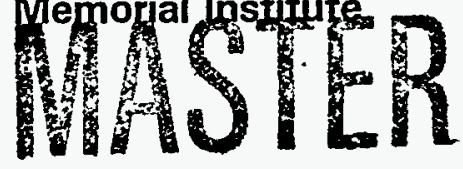




\section{Detailed Design Data Package: Item 3.1a - Film Cooler Pressure Drop Data; Item 3.2a - SBS Packing Selection; Item 3.2b, 3.2c - Pressure Drop Data for SBS Distribution Plate; and Item 3.2e - SBS Distribution Plate and Liquid Risers. PHTD Pilot-Scale Melter Testing System Cost Account Milestone 1.2.2.04.15A}

G. A. Whyatt

L. D. Anderson

J. Evans, II

March 1996

Prepared for

the U.S. Department of Energy

under Contract DE-AC06-76RLO 1830

Pacific Northwest National Laboratory

Richland, Washington 99352 


\title{
DISCLAISMER
}

This report was prepared as an account of work sponscred by an agency of the United States Covernment. Neither the United States Covernment nor any agency thereof, nor Eartelle Nemorial Instituie, nor any of their employees, makes any warranty, express or implied, or assumes any legal liability or responsibility for the accuracy, complefeness, or.usefulness of any information, apparatus, product, or process disclosed, or represents that its use would not infringe privately owned rights. Referenice herein io any speciric commerciel product, process, or senvice by

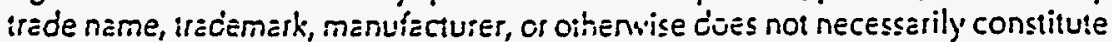
or imply its endorsement, recommenciation, or favoring by the United States Government or any agency therfof, or Bañelle Memorial Instiute. The views and opinions of authors expressed herein do not necessarily state or reilect those of the United States Government or any agency thereof.

\author{
PACIFIC NORTHWEST NATIONAL LABORATORY \\ operaied by \\ BATTELLE \\ for the \\ UNITED STATES DEPARTMENT OF, ENERGY \\ under ContraCt DE-ACO6-76RLO 1830
}

Prinled in the Uniled States of America

Available to DOE and DOE contractors from the

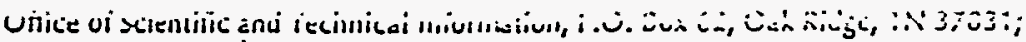
prices available from (615) 576-8401.

Available to the public from the National Technical information Senvice, U.S. Department of Commerce, 5285 Port Royal Rd., Springfield, VA 22161 


\section{TABLE OF CONTENTS}

SUMMARY

S. 1

1.0 DATA NEED 3.1a - Film Cooler Pressure Drop Data. 1.1

1.1 Normal Conditions

1.10

1.2 Maximum Plenum Temperature Conditions

1.19

1.3 Steam Surge Conditions

1.4 Pressure Drop vs'Steam Flow

1.27

1.35

2.0 DATA NEEDS $3.2 a, b, c, e$ - SBS DATA

$2 \cdot 1$

2.1 Data Collection

$2 \cdot 2$

2.2 Summary of Requested Data

2.3 Chevron Demister Pressure Drop

2.8

2.4 SBS Pressure Drop vs Flow

2.11

2.5 SBS Bed Temperatures

2.13

2.6 Energy Balances

2.7 Comparison of Inlet and Outlet Flowrates

2.19

2.25

2.27

2.8 Estimate of SBS Bed Void Fractions

2.29

2.9 SBS Scrub Tank Circulation Velocities

2.31

2.10 SBS Bed Utilization

2.35

2.11 Cooling Coil Heat Transfer Coefficients

2.12 Pressure Oscillations in Offgas System

\section{APPENDICES}

APPENDIX A: SPECIFIC CASE DATA FOR DATA NEED 3.2 APPENDIX B: FLOUR DATA NEED SHEETS FOR 3.1 AND 3.2 APPENDIX C: SBS DRAWINGS 


\section{Figures}

1.1a LFCM Film Cooler Schematic

1.5

1. Ib LFCM Film Cooler Tip Modifications

1.6

1.2 Reamer Brush Section of Offgas Iine

1.9

1.3 Schematic of Offgas Line

1.4 Normal Case Offgas Flowrate vs. Time

1.5 Normal Case Film Cooler Pressure Drop vs. Time

1.8

1.13

1.6 Normal Case Offgas Iine Pressure Drop vs. Time

1.14

1.7 Normal Case Relative Melter Plenum piessure vs. Time

1.15

1.8 Normal Case SBS Offgas Inlet Temperature vs. Time

1.16

1.9 Normal Case Melter Plenum Temperature vs. Time

1.17

1.10 Maximum Plenum Temperature Case Offgas Flow vs. Time

1.18

1.21

1.11 Max Plenum Temp Case Film Cooler Pressure Drop

1.22

1.12 Max Plenum Temp Case Offgas Iine Pressure Drop

1.23

1.13 Max Plenum Temp Case Relative Melter Plenum Pressure

1.24

1.14 Max Plenum Temp Case SBS Offgas Inlet Temperature

$1.15 \mathrm{Max}$ Plenum Temp Case Melter Plenum Temperature

1.25

1.26

1.16 Steam Surge Case Offgas Flowrate vs. Time

1.17 Steam Surge Case Film Cooler Pressure Drop

I.18 Steam Surge Case Offgas Line Pressure Drop

1.19 Steam Surge Case Relative Melter Plenum Pressure

1.20 Steam Surge Case SBS Offgas Inlet Temperature

1.21 Steam Surge Case Melter Plenum Temperature

1.29

1.30

1.31

1.32

1.33

1.34

1.22 Film Cooler. Pressure Drop vs. Offgas Jumper Flowrate 1.37

1.23 Offgas Line Pressure Drop vs. Offgas Jumper Flow 1.38

2. I Chevron Demister Schematic

2.2 Location of Type $J$ Thermocouples in SBS Bed

2.3 Chevron Demister Head Loss vs. Approach Velocity

2.4 SBS Total Pressure Drop vs. Superficial Velocity

2.6

2.12

2.5 Corrected SBS Pressure Drop vs. Superficial Velocity

2.6 SBS Bed Pressure Drop vs. Superficial Velocity

2.7 SGS Bed Pressure Drop vs. Superficial Velocity

2.8 Bed Temperature Variation by Bed Sector

2.17

2.18

2.9 Bed Temperature Variation by Vertical Position

2.20

2.20

2.21

2.21

2.22

2.11 Vertical Bed Temperature Variation at Startup

2.12 5-Second SBS Temperature Data- upper bed region

2.23

2.13 5-Second SBS Temperature Data- middle bed region

2.14 5-Second SBS Temperature Data- Lower bed region

2.24

2.15 Air Only Flow Rate Comparison Before and After SBS

2.16 SBS Bed Void Fraction vs. Superficial Velocity

2.28

2.17 Estimated Actual Velocity of Gas in SBS Bed

2.30

2.18 Superficial Iiquid Velocity vs. Superficial Gas Vel. 2.34 


\section{Tables}

S.1 Data Summary for 3.1a - Film Cooler Pressure Drop $\$ .2$

S.2 Data Summary for 3.2 - SBS Data 5.3

1.1 Fluor Data Need 3.1a Summary Sheet $\quad 1.2$

1.2 Normal Case Summary

1.3 Maximum Plenum Temperature Case Summary

1.4 Steam Surge Case Summary

1.5 Effect of Steam Flow on Film Cooler/Offgas Line DP

2.1 Flour Data Need $3.2 \mathrm{a}, 3.2 \mathrm{~b}, 3.2 \mathrm{c}$ and $3.2 \mathrm{e}$ Summary 2.1

2.2 Circulation Velocities

2.3 SBS Bed Utilization

2.31

2.4 Cooling Coil Heat Transfer Coefficient

2.35

2.5 Offgas System Oscillations

2.36

2.6 Offgas System Oscillation Magnitudes 
This data package transmits information collected on the Iiquid-Fed Ceramic Melter (IFCM) offgas system prior to melter feeding operations. Injection of steam to the melter plenum was used to simulate feeding of the melter. Steam surge cases were studied under steady-state surge conditions. Dynamic surges will be examined under data needs 3.3 and 3.6 to be provided later. This data package provides information requested by Fluor Daniel in data needs:

$\begin{array}{ll}3.1 \mathrm{a} & \text { Film Cooler Pressure Drop Data } \\ 3.2 \mathrm{a} & \text { SBS Packing Selection } \\ 3.2 \mathrm{~b}, \mathrm{c} & \text { Pressure Drop Data For SBS Distribution Plate } \\ 3.2 \mathrm{e} & \text { SBS Distribution Plate and Liquid Risers }\end{array}$

The Fluor data needs included two blank tables requesting specific information for data needs 3.1 and 3.2 .1 These tables are provided in Tables 5.1 and $S .2$ below with the requested information filled in.

In data need 3.1, the pressure drop across the film cooler and offgas line were measured at a variety of conditions. The downstream film cooler pressure tap was located downstream of the reamer brush support section due to difficulties encountered when trying to obtain accurate readings at the exit of the film cooler. Therefore, the reported pressure drops for the film cooler include the reamer brush section. The observed pressure drops for the film cooler and the offgas line were slightly higher than estimated using standard pressure drop estimating techniques for piping systems. The IFCM film cooler is not prototypic of the HWVP film cooler.

In data need 3.2 , the pressure drop and operating characteristics of the SBS were studied over a range of conditions. The test condition specified as $51.2 \mathrm{spm}$ air/29 $\mathrm{lb} / \mathrm{h} / \mathrm{ft}^{2}$ steam represents an evaporating condition. If this condition is utilized in the HWVP, a makeup water supply will be required.

1 The data need $3.1 \mathrm{a}$ will be referred to as need 3.1 and the various subgroups of 3.2 will be collectively referred to as need 3.2 . 
TABLE S.1 Data Summary for Fluor Daniel Technical Need Item No 3.1a - Film Cooler Pressure Drop

\begin{tabular}{|c|c|c|c|c|c|c|c|}
\hline $\begin{array}{l}\text { Melter } \\
\text { Air } \\
\text { Flow' } \\
\text { 'SCFM }\end{array}$ & $\begin{array}{c}\text { Plenum } \\
\text { Temp } \\
{ }^{\circ} \mathrm{F}\end{array}$ & $\begin{array}{l}\text { Plenum } \\
\text { Press } \\
\text { psia }\end{array}$ & $\begin{array}{l}\text { Film } \\
\text { Cooler } \\
\text { Air Flow. } \\
\text { lb/hr }\end{array}$ & $\begin{array}{c}\text { SBS } \\
\text { Inlet } \\
\text { Temp } \\
{ }^{0} \mathrm{~F} \\
.\end{array}$ & $\begin{array}{l}\text { Film } \\
\text { Cooler } \\
\text { Pressure } \\
\text { Drop } \\
\text { "WC }\end{array}$ & $\begin{array}{l}\text { Offgas Line } \\
\text { Pressure } \\
\text { Drop " WC }\end{array}$ & Case \\
\hline $\begin{array}{c}53 \\
(58)^{b} \\
\end{array}$ & $\begin{array}{c}1330 \\
(1302) \\
\end{array}$ & 14.15 & $\begin{array}{r}777 \\
(812) \\
\end{array}$ & 586 & 2.1 & 3.6 & Normal \\
\hline $\begin{array}{r}56 \\
(58) \\
\end{array}$ & $\begin{array}{l}<1330 \\
(1043) \\
\end{array}$ & 14.26 & $\begin{array}{r}777 \\
(762) \\
\end{array}$ & 686 & 11.6 & 14.4 & Surge \\
\hline $\begin{array}{c}53 \\
(41) \\
\end{array}$ & $\begin{array}{l}1450 \\
(1426)\end{array}$ & 14.22 & $\begin{array}{c}901 \\
(908) \\
\end{array}$ & 587 & 2.1 & 3.8 & $\begin{array}{c}\text { Max Plenum } \\
\text { Temp }\end{array}$ \\
\hline
\end{tabular}

a) Target values are given. Actual recorded values are shown in parenthesis.

b) Air Flows in ACFM evaluated at Plenum Temperature and Plenum Pressure are $204, .173$ and 154. ACFM.

c) Plenum pressure target is -7 "WC gauge. Barometric pressure was recorded on the day of testing, and actual relative pressure was used to calculate psia pressure.

d) The pressure drop is measured from the melter plenum to a location 6-in. past the downstream flange of the reamer brush section. Therefore, the pressure drop includes the film cooler as well as the section of offgas pipe on which the reamer brush will be mounted. 
Table S.2 Data Summary for Fluor Daniel Technical Need Item Nos. 3.2a, 3.2b, 3.2c and $3.2 e$

\begin{tabular}{|c|c|c|c|c|c|c|c|c|}
\hline $\begin{array}{c}\text { Air } \\
\text { Superficial } \\
\text { Velocity } \\
\text { fpm }\end{array}$ & $\begin{array}{l}\text { Steam Flow } \\
\text { lb/hr } \mathrm{ft}^{2}\end{array}$ & $\begin{array}{l}\text { SBS } \\
\text { Press } \\
\text { Drop } \\
\text { "WC }\end{array}$ & $\begin{array}{c}\text { DF } \\
\text { under } \\
1 \\
\text { micron } \\
\end{array}$ & $\begin{array}{c}\text { DF } \\
\text { over } \\
1 \\
\text { micron } \\
\end{array}$ & $\begin{array}{l}\text { Gas } \\
\text { Inlet } \\
\text { Temp } \\
\end{array}$ & $\begin{array}{c}\text { Gas } \\
\text { outlet } \\
\text { Temp } \\
\substack{\mathrm{O} \\
\mathrm{F}}\end{array}$ & $\begin{array}{c}\text { SBS Bed } \\
\text { Temp } \\
\end{array}$ & Case \\
\hline $60 \quad(62.8)$ & $29 \quad(27.3)$ & 41.3 & $g$ & 9 & 692.6 & 124.3 & 126.5 & Normal \\
\hline $62 \quad(80.9)$ & $201(199.3)$ & 46.3 & 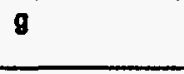 & $\mathbf{g}$ & 657.7 & 122.2 & 125.4 & Surge \\
\hline $120(124.6)$ & $29 \quad(29.4)$ & 41.4 & $\mathbf{g}$ & $g$ & 695.7 & 124.5 & 126.7 & Normal \\
\hline $123(111.7)$ & $201(201.3)$ & 44.7 & $\mathbf{g}$ & $\mathbf{g}$ & 555.6 & 120.3 & 122.7 & Surge \\
\hline $180(148.8)$ & $(0)$ & 42.4 & $\mathbf{g}$ & g & 400.8 & 122.5 & 124.3 & No $S t m$ \\
\hline $180^{c}(178.1)$ & $(0)$ & 50.2 & $\mathrm{~g}$ & 9 & 90.0 & 68.5 & 69.1 & No $s t m$ \\
\hline $51.2^{d}(53.6)$ & $29 \quad(26.8)$ & 42.7 & 9 & $\mathrm{~g}$ & 600.3 & 125.6 & 126.7 & Normal \\
\hline $51.2^{d}(54.3)$ & $201(189.1)$ & 43.1 & 9 & 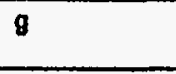 & 579.4 & 154.8 & 157.3 & Surge \\
\hline $51.2^{d}(62.4)$ & $201(199.5)$ & 45.2 & g & 9 & 601.9 & 116.8 & 119.3 & Surge \\
\hline
\end{tabular}

- Reference conditions are SBS outlet conditions unless indicated otherwise. Requested flow rates are shown, actual flow rates achieved are given in parenthesis.

b HEME was bypassed in all cases.

c A repeat of the requested data in the previous line except that the offgas line was removed and air was be drawn directly into SBS, rather than through the melter. The SBS pressure drop was configured to be measured without the effect of the demister. Correction is made for entrance effect of disconnected offgas line. 
In Standard fpm, $14.7 \mathrm{psia}$ and $60^{\circ} \mathrm{F}$. This flow rate provides the Fluor requested superficial velocity of $0.26 \mathrm{~m} / \mathrm{s}$.

Target mass flow rates are shown, with actual flow rates given in parenthesis.

The estimated pressure drop across the chevron demister has been subtracted from this value. The estimated pressure drop at the entrance flange to the SBS has also been subtracted when the offgas line was not in place. No data. DF measurements require feeding of the melter. 
The overall pressure drop of the SBS including the frictional losses in the downcomer and chevron demister increases significantly with flowrate. The submergence of the SBS is 39.2 inches (corresponding to the pressure drop at nearly zero flow). Pressure drops of nearly 100 in. WC were recorded at the maximum flowrates. However, the majority of this increase is the result of frictional losses in the chevron demister at the SBS

exit. Removing the contribution from the demister reduces the variation of pressure drop with flow. Values in Table 5.2 have the effect of the demister removed. If the frictional losses in the demister and downcomer pipe are excluded, the pressure drop for the SBS is primarily due to the submergence of the downcomer exit. The pressure drop for the distribution plate and packing increased approximately 5 inches above the initial submergence, . presumably due to the formation of a bubble beneath the plate.

Oscillations with a frequency of $3 \mathrm{~Hz}$ and magnitude ${ }^{2}$ of 1.6 to $4.0 \mathrm{in}$. WC were noted during operation of the SBS. The oscillation is believed to be a general property of a submerged, packed bed and is not believed to be due to the distribution plate or packing used. Pressure drop data indicated that the packed bed has a pressure drop vs. flow curve containing a maximum. It is believed that this maximum leads to the instability. Providing improved access of the offgas to the area beneath the plate reduces the frequency of the oscillation. Removal of the offgas line reduces the frequency to 0.8 to 0.9 $\mathrm{Hz}$. Frequencies of 0.4 to 0.55 were reported for the submerged gravel scrubber which had a less restricted downcomer than the IFCM SBS (see section 2.11). The presence of the oscillation should not interfere with SBS operation but it does make control of the melter plenum pressure more difficult and causes oscillations in offgas flowrate readings taken using pitot tubes.

The void fraction in the SBS increased nearly linearly up to superficial velocities of $60-80 \mathrm{ft} / \mathrm{min}$ (exit conditions, including humidity). At this point the curve begins to level off. At the maximum flow tested the bed volume was still approximately $1 / 3$ by volume liquid. The liquid was not blown completely out of the bed over the range tested. It is believed that the intalox saddle packing with a void fraction of 0.75 helped prevent all of the liquid from being blown out.

2 magnitude measured from crest to trough so that a 4 inch magnitude would oscillate plus or minus 2 inches about a mean value. 


\subsection{FLUOR DANIEL TECHNOLOGY NEED DATA SHEET 3.19 - FIIM COOLER PRESSURE DROP}

Fluor data need 3.1 a requested several process variables be measured with a focus on the pressure drop in the film cooler and offgas line leading to the SBS. A summary of the information requested is provided in Table 1.1. Data was requested for each of three cases; a Normal Case in which the conditions are nominal, a Steam Surge case, and a Maximum Plenum Temperature case. Below is a description of the basis for the flowrates selected and how the data was measured. The sections that follow provide additional information on each of the specific cases.

\section{Film Cooler Air Injection}

The nominal film cooler air injection rate was set based on an HWVP flow of $50 \mathrm{lb} \mathrm{mol} / \mathrm{h}$ and scaled based on film cooler throat area. The HWVP film cooler has a throat inside diameter of 5.5 in. The IFCM film cooler is non-prototypic and has an inside diameter of 4.026 in. This results in a target film cooler air injection rate of $26.8 \mathrm{lb} \mathrm{mol} / \mathrm{h}(777 \mathrm{lb} / \mathrm{h}$ or 170 SCFM) •

Film cooler air flow was measured by a pitot tube in the air supply line, a reading of the static pressure in the line, and the temperature of the air being injected. The flowrate was sampled at 2-second intervals and 1 -minute averages were recorded.

Melter Steam Flow

The melter steam flow was based on HWVP flows of $19.5 \mathrm{lb}$ $\mathrm{mol} / \mathrm{h}$ under normal conditions and $133.1 \mathrm{lb} \mathrm{mol} / \mathrm{h}$ under surge conditions. This surge represents a 7-fold increase in steam generation within the melter. The normal value includes moisture entering in inleakage so the values do not differ by an exact multiple of seven. The steam surge was scaled by film cooler throat area to arrive at IFCM target flows of 10.5 and $71.3 \mathrm{lb}$ mol/h under normal and surge conditions respectively.

The steam flow was measured using a vortex shedding flowmeter and a pressure gauge installed on the steam supply line. A thermocouple was also installed on the steam line to confirm that approximately saturated conditions existed. 
TABLE 1.1 Data Summary for Fluor Daniel Technical Need Item No 3.1a - Film Cooler Pressure Drop

\begin{tabular}{|c|c|c|c|c|c|c|c|}
\hline $\begin{array}{l}\text { Melter } \\
\text { Air } \\
\text { Flow } \\
\quad \text { SCFM }\end{array}$ & $\begin{array}{c}\text { Plenum } \\
\text { Temp } \\
{ }^{\circ} \mathbf{F}\end{array}$ & $\begin{array}{c}\text { Plenum } \\
\text { Press } \\
\text { psia }\end{array}$ & $\begin{array}{l}\text { Film } \\
\text { Cooler } \\
\text { Air Flow } \\
\quad l b / h r\end{array}$ & $\begin{array}{c}\text { SBS } \\
\text { Inlet } \\
\text { Temp } \\
{ }_{F}^{0}\end{array}$ & $\begin{array}{l}\text { Film } \\
\text { Cooler } \\
\text { Pressure } \\
\text { Drop } \\
\text { "WC }\end{array}$ & $\begin{array}{l}\text { Offgas Line } \\
\text { Pressure } \\
\text { Drop " WC }\end{array}$ & Case \\
\hline $\begin{array}{c}53 \\
(58)^{b}\end{array}$ & $\begin{array}{c}1330 \\
(1302) \\
\end{array}$ & 14.15 & $\begin{array}{r}777 \\
(812) \\
\end{array}$ & 586 & 2.1 & 3.6 & Normal \\
\hline $\begin{array}{c}56 \\
(58)\end{array}$ & $\begin{array}{l}<1330 \\
(1043)\end{array}$ & 14.26 & $\begin{array}{c}777 \\
(762) \\
\end{array}$ & 686 & 11.6 & 14.4 & Surge \\
\hline $\begin{array}{c}53 \\
(41)\end{array}$ & $\begin{array}{c}1450 \\
(1426)\end{array}$ & 14.22 & $\begin{array}{c}901 \\
(908)\end{array}$ & 587 & 2.1 & 3.8 & $\begin{array}{c}\text { Max Plenum } \\
\text { Temp }\end{array}$ \\
\hline
\end{tabular}

a) Target values are given. Actual recorded values are shown in parenthesis.

b) Air Flows in ACFM evaluated at Plenum Temperature and Plenum Pressure are 204, 173 and 154 ACFM.

c) Plenum pressure target is -7 "WC gauge. Barometric pressure was recorded on the day of testing, and actual relative pressure was used to calculate psia pressure.

d) The pressure drop is measured from the melter plenum to a location 6-in. past the. downstream flange of the reamer brush section. Therefore, the pressure drop includes the film cooler as well as the section of offgas pipe on which the reamer brush will be mounted. 
Melter Air Flow

The target melter plenum air flow was based on HWVP flows of $15.5 \mathrm{lb}-\mathrm{mol} / \mathrm{h}$ (normal) and $16.6 \mathrm{lb}-\mathrm{mol} / \mathrm{h}$ (surge) air flow from the melter. The target and actual flows are reported in SCFM since this makes an easier comparison to lb-mol/h targets than does ACFM. Scaling was based on a ratio of film cooler throat cross-sectional areas. Therefore, the target melter air flows from the melter were $8.3 \mathrm{lb}$-mol/hr (normal) and $8.9 \mathrm{lb}-\mathrm{mol} / \mathrm{h}$ (surge). This corresponds to flows of 52.5 SCFM and 56.2 SCFM (Ref. 60 F, 1 atm).

The flow of air from the melter was determined by subtracting the film cooler air injection and plenum steam injection from the total flow in the offgas jumper. A check was made using the SBS exit flow as well. The desired flow of air from the melter was approximately equal to the air inleakage. Although the capability existed to inject air into the plenum, this was not performed since the flow was approximately correct without injection. Control air was not injected into the offgas jumper during any measurements. Measurements of total offgas flow were made using dual pressure transducers connected to pitot tubes both before and after the SBS. The pressure readings from the dual transducers were averaged. Corrections for the average molecular weight of the gas due to the presence of steam were made for the pitot tube located downstream of the SBS. The resulting dry air flow was then used along with the steam injection rate to determine the correction required for the pitot tube in the offgas jumper. Humidity in air inleakage was ignored in the specific gravity correction to the flow in the offgas jumper.

- The steam flow rate, steam temperature, off-gas flowrate, corrected flowrate, and post-sBS flowrate were ali sampled at 2 second intervals and the 1 -minute averages are recorded. In addition, the minimum and maximum flows for the offgas flowrate and post-sBS flowrate were recorded each minute.

\section{Plenum Temperature}

A target plenum temperature of $1330^{\circ} \mathrm{F}$ was provided by Fluor. The plenum temperature was measured by two type $\mathrm{K}$ thermocouples in the melter plenum located 8 " and 12" above the glass melt. The temperature was sampled at two second intervals and the oneminute averages were recorded. The two thermocouples were averaged together over a 10 minute period to obtain the reported values.

\section{Plenum Pressure}

The plenum pressure was determined by determining the total atmospheric pressure during the time of the test and subtracting the relative pressure of the plenum. Atmospheric pressure readings, corrected for 300 area elevation, were obtained from

$$
1.3
$$


the PNL weather station for the time the data was collected. As a check, readings were taken from an indication-only barometer during the test as well.

The relative plenum pressure was sampled at 2-second intervals and the one-minute average was recorded. In addition the minimum and maximum recorded value sampled each minute was also recorded.

The plenum pressure was adjusted to approximately -7 " WC relative to the atmosphere. The pressure was measured using a General Electric pressure transducer calibrated to a +10 " to -30 " differential range. No target for plenum pressure was specified on an absolute pressure basis.

\section{SBS Inlet Temperature}

The SBS offgas inlet temperature was measured by a type $\mathbb{K}$ thermocouple in the offgas line just above the top of the SBS. One minute averages of 2 -second samples were recorded.

Film Cooler Pressure Drop (in. WC)

A sketch of the film cooler is shown in Figure 1.1a. The tip of the film cooler has since undergone a minor modification as shown in Figure 1.1b. The pipe section attached to the film coolex is designed to incorporate a reamer brush and is shown in Figure 1.2. Initial attempts to measure the pressure drop across only the film cooler resulted in unreliable results. Because of this the pressure taps for measuring film cooler pressure drop were placed in the melter plenum and in the offgas line at a location 6" downstream of the reamer brush section. The tap was drilled horizontally through the side of the pipe. Due to the location of the taps, the readings include the reamer brush section. In order to increase accuracy of the measurements, no control air was injected into the offgas line between the film cooler and the SBS. The measurement of film cooler DP was made using a Validyne differential pressure transducer with a 14-in. WC full-scale reading. The data logger was configured to scan the pressure drop every 2 seconds. The average, maximum, and minimum values were recorded once per minute. 

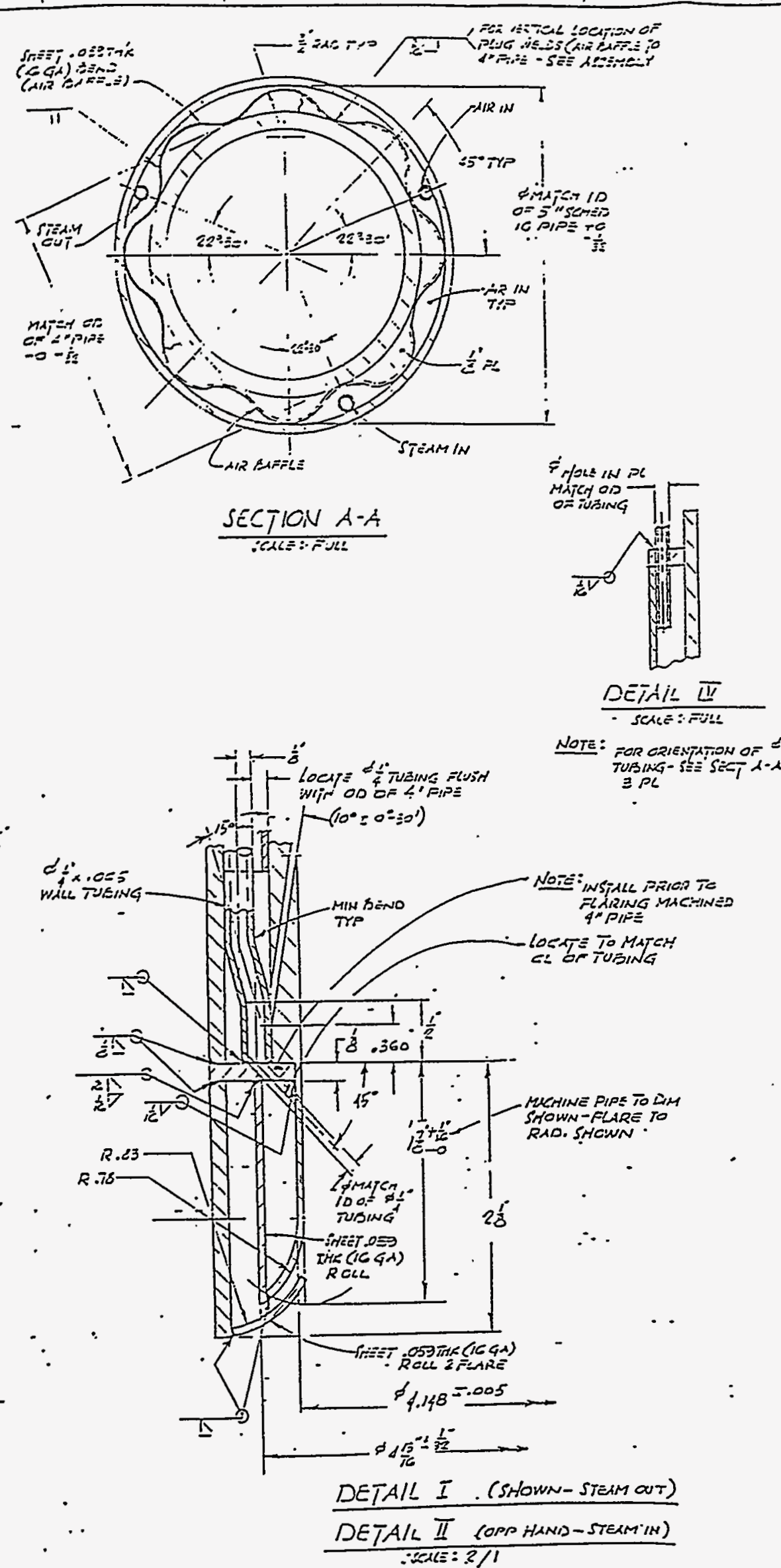

$\frac{15^{\circ}}{10}$

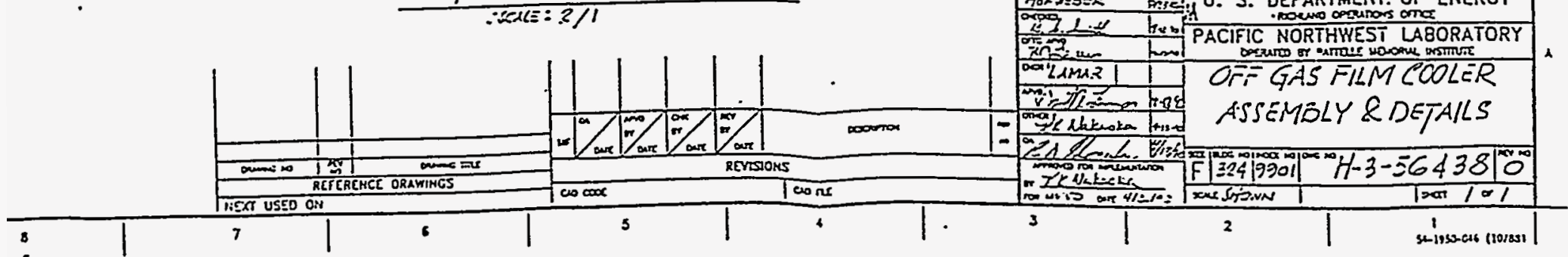




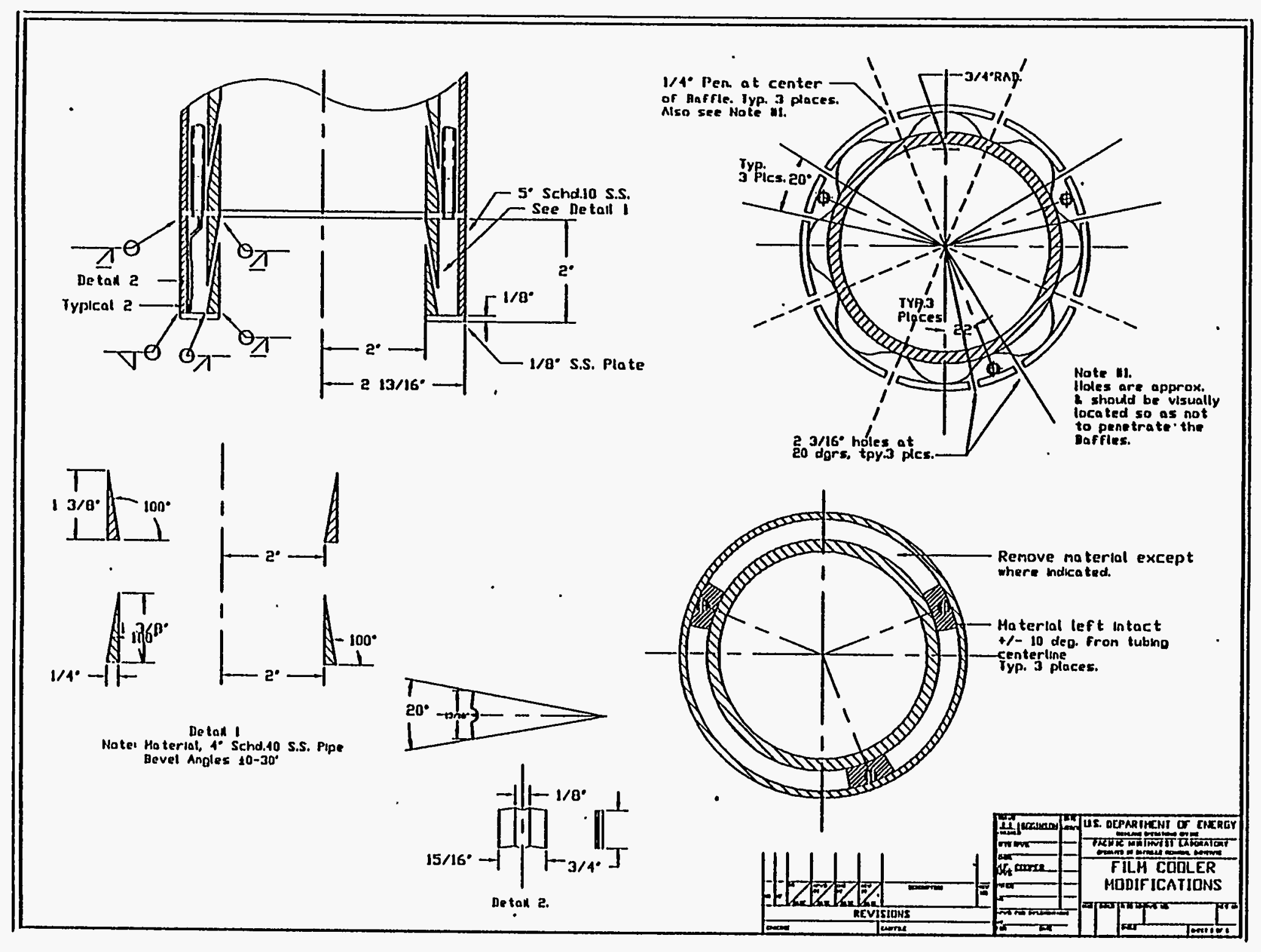

Figure 1.1b LFCM Film Cooler Tip Modification 


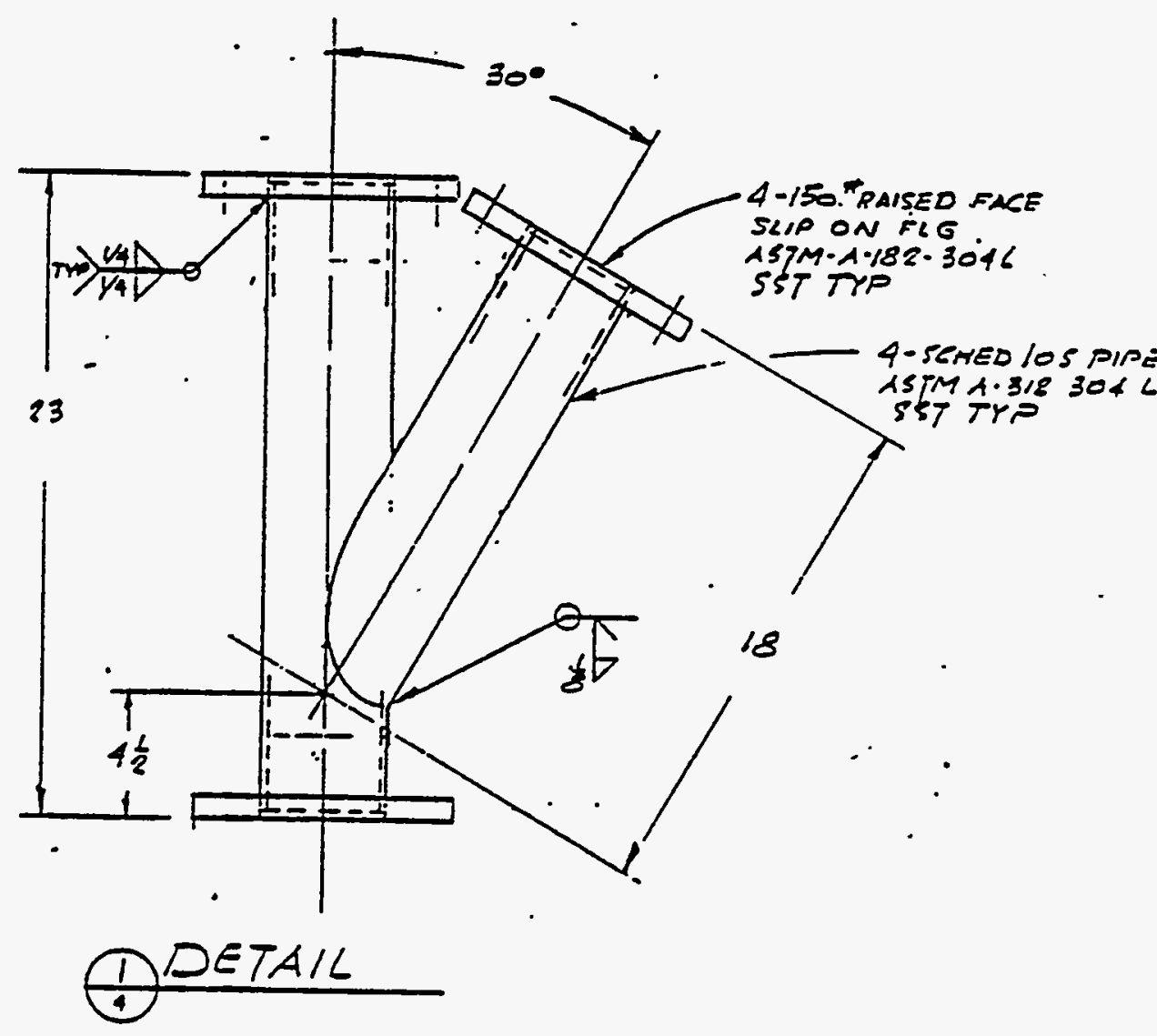

Figure 1.2 Reamer Brush Section of Offgas Line 
Film Cooler/Off-gas Line Pressure Drop (in. WC)

This data point represents the pressure drop through the offgas line from the film cooler downstream pressure tap ( 6 " past the reamer brush pipe section) to the top of the SBS downcomer. A sketch of the offgas line is shown in Figure 1.3. The offgas line consists of approximately 207" of curved, 4-in., schedule 40 pipe with a radius of curvature of 79 in., followed by an

expansion to 4-in. schedule 10 pipe, 122 in. of straight pipe and finally contraction to $4-i n$. schedule 40 pipe. The measurement of pressure drop was made using a 22.2-in. full-scale validyne pressure transducer. The upstream tap was the same as the downstream tap for the film cooler. The downstream tap is located 3.5-in. past the flange connection of the SBS downcomer and the offgas line. The pressure drop was sampled every 2 seconds and the average, minimum and maximum value was recorded once per minute. 
.

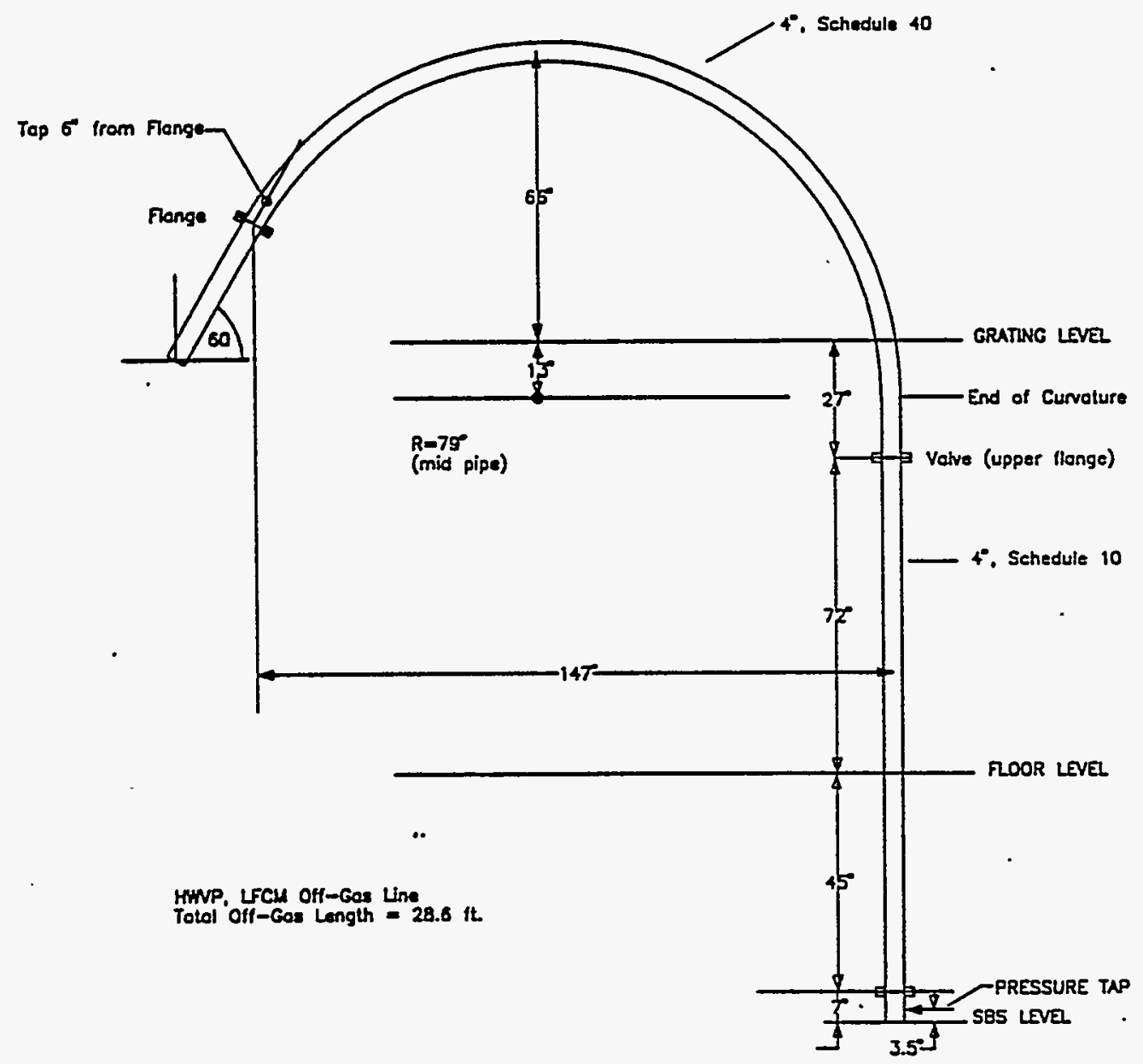

Figure 1.3 Schematic of LFCM Offgas Iine

1.9 


\subsection{NORMAL CASE}

A summary of the information for all cases was provided in Table 1.1. The information on conditions during testing under normal conditions are shown in Table 1.2 below. The "Target" value represents that which was desired for the test. The "Average" heading describes the average of readings over 10 minutes or more of steady operation. The "Average Maximum" heading represents the average over the run period of the 1minute maximum readings for those variables where maximum and minimum values were recorded each minute. The "Average Minimum" value represents a similar value where the minimums are recorded for each minute of operation.

Table 1.2 Normal Case Conditions

\begin{tabular}{|c|c|c|c|c|}
\hline & Target & Average & $\begin{array}{l}\text { Average } \\
\text { Maximum }\end{array}$ & $\begin{array}{l}\text { Average } \\
\text { Minimum }\end{array}$ \\
\hline Melter Air Flow & 53 & $50^{1}$ & $--^{2}$ & - \\
\hline $\begin{array}{l}\text { Film Cooler Air Flow } \\
(\mathrm{lb} / \mathrm{h})\end{array}$ & 777 & 812 & - & - \\
\hline Steam Injection & 189 & 194 & - & - \\
\hline Plenum Pressure & - & 14.15 & 14.23 & 14.08 \\
\hline Plenum Temperature $\left.\quad{ }^{\circ} \mathrm{F}\right)$ & 1330 & $1302^{3}$ & - & - \\
\hline SBS Inlet Temperature $\left({ }^{\circ} \mathrm{F}\right)$ & - & 586 & - & - \\
\hline Film Cooler DP ("WC) & - & $2 \cdot 1^{4}$ & 3.0 & 0.03 \\
\hline Offgas Line DP & - & 3.6 & 5.2 & 2.0 \\
\hline
\end{tabular}

1 Calculated from the SBS exit stream this value would be 62 SCFM. For this data point, the value calculated from offgas flow (shown in Table) is believed to be more accurate.

- no data or no target established

The two measured plenum temperatures differed by $18^{\circ} \mathrm{F}$. The average of the two fell from 1324 to 1281 over the 10 minute data collection period.

The pressure drop is measured from the melter plenum to a location 6-in. past the downstream flange of the reamer. brush section. Therefore, the pressure drop includes the film cooler as well as the section of offgas pipe on which the reamer brush will be mounted. 
Comparison to Estimated Pressure Drops

The film cooler pressure drop (including reamer brush section) can be compared to that estimated for flow of the gas mixture through a slightly simplified system. The film cooler is approximated by a protruding entrance loss, 23 in. of 4-in. schedule 40 pipe, a sudden expansion to 4 -in. schedule 10 pipe, a 30 degree miter bend, 14.5. in. of 4-in. schedule 10 pipe, a sudden contraction to 4 -in. schedule 40 pipe, and 6 in. of 4 -in. schedule 40 pipe. The gas density and viscosity were calculated using the steam injection rate and assuming no moisture in the air inleakage and film cooler injection. It was assumed that the film cooler injection air is entering from the melter. This calculation results in a pressure drop of 1.6 in. This is in reasonable agreement with the average value of 2.1 in. measured during the test.

The offgas line pressure drop was estimated using a similar procedure, calculating the pressure drop as 4-in. schedule 40 pipe bending through 150 degrees on a 79-in. radius, an expansion to 4-in. schedule 10, 122 in. of straight schedule 10 pipe, and a contraction to 4 in. schedule 40 pipe. This results in an estimated pressure drop of 2.6 in. which is slightly less than the average value observed of 3.6 in.

Energy Balance over SBS During Operation

As a check on the process conditions an energy balance was performed. The enthalpy from the temperature change in inlet air and steam and condensation of steam was compared to the heat removed from the SBS in the cooling coils, an estimate of convective losses and the temperature change in the SBS over the operation period. For this case the error in the energy balance was 6.78 in error. This is considered reasonable especially in light of the fact that the temperature change $(2.7 \mathrm{C})$ accounted for $41 \%$ of the enthalpy during the period in question.

Comparison of Upstream and Downstream Non-Condensable Flowrates In addition, calculations were made of the air-only flow rate before and after the SBS to compare the readings. If there were no inleakage to the SBS, these readings should be in agreement. The average air-only flows were 228 scfm in the offgas line and $239 \mathrm{scfm}$ exiting the SBS. Considering the fluctuations in the readings, and the assumptions required for the calculation such as no humidity in the melter inleakage, this is considered good agreement.

System Variables During Period of Interest

plots of the data for the period during which data was obtained are shown on the following pages in Figures 1.4 through 1.9. The purpose of these plots is to illustrate the degree of fluctuations experienced during a period of steady operation in 
which data was collected. For the Normal Case, the offgas.

flowrate fluctuated up to $10 \%$ about the mean flowrate. The 1minute average pressure drops and SBS temperatures were fairly steady. The plenum temperature decreased over the data collection period. A significant decrease in plenum temperature would have the effect of decreasing the ACFM air flow entering the throat of the film.cooler. However, in this case, the impact on film cooler pressure drop should be negligible.

The data points plotted are 1-minute averages of the observed readings. These data points are then averaged to arrive at the values provided in Table 1.2. In general, single offgas flow and pressure measurements tended to fluctuate about a mean value with a frequency of about 3 hertz. This fluctuation is believed to originate in the SBS and is discussed further along with data need 3.2 . 


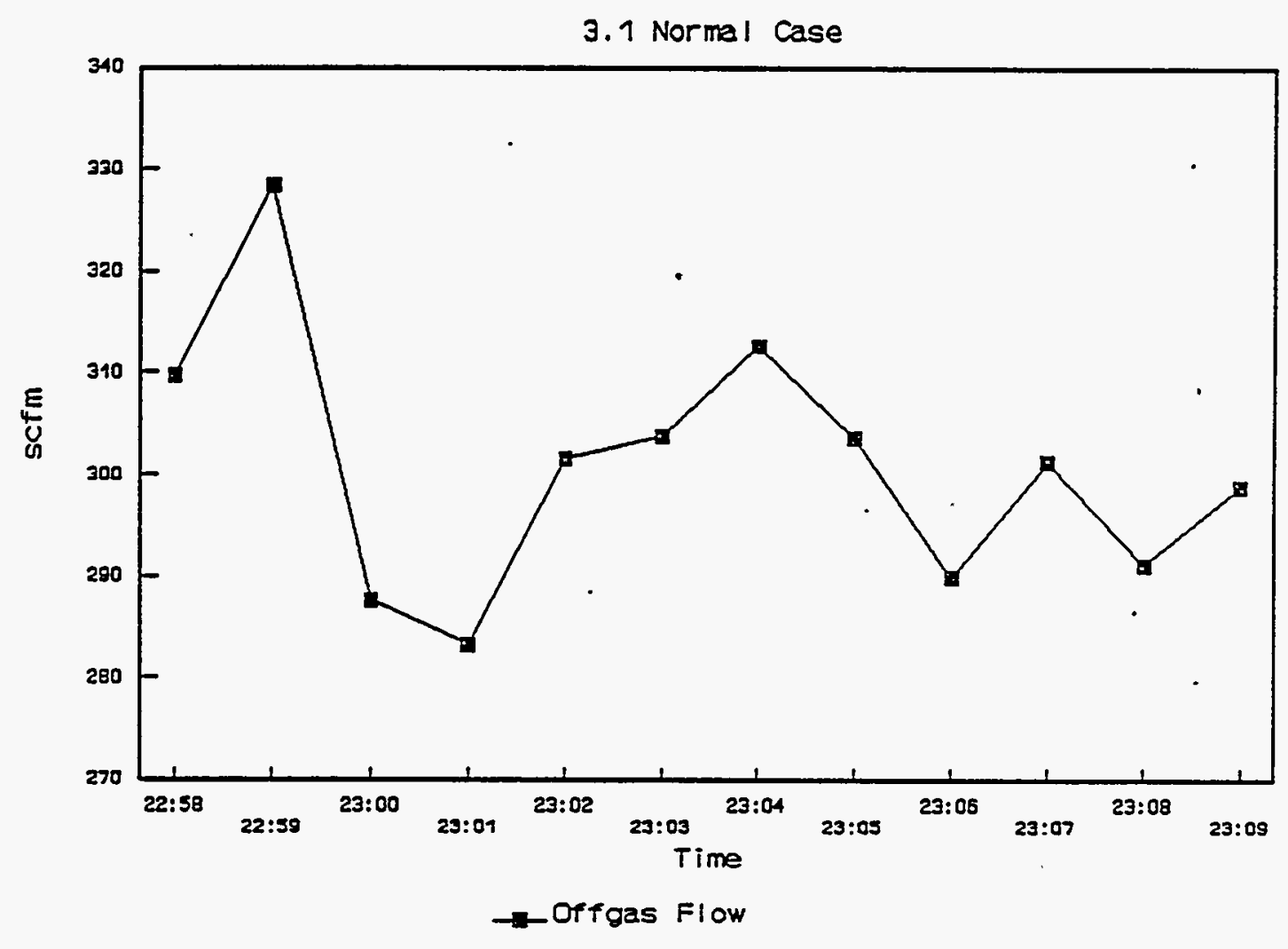

Figure 1.4: Total Gas Flow in the off-gas Jumper for the Normal Case. Average value of offgas flow was 300.95 scfm. (includes air and steam).

1.13 
3.1 Normal Case

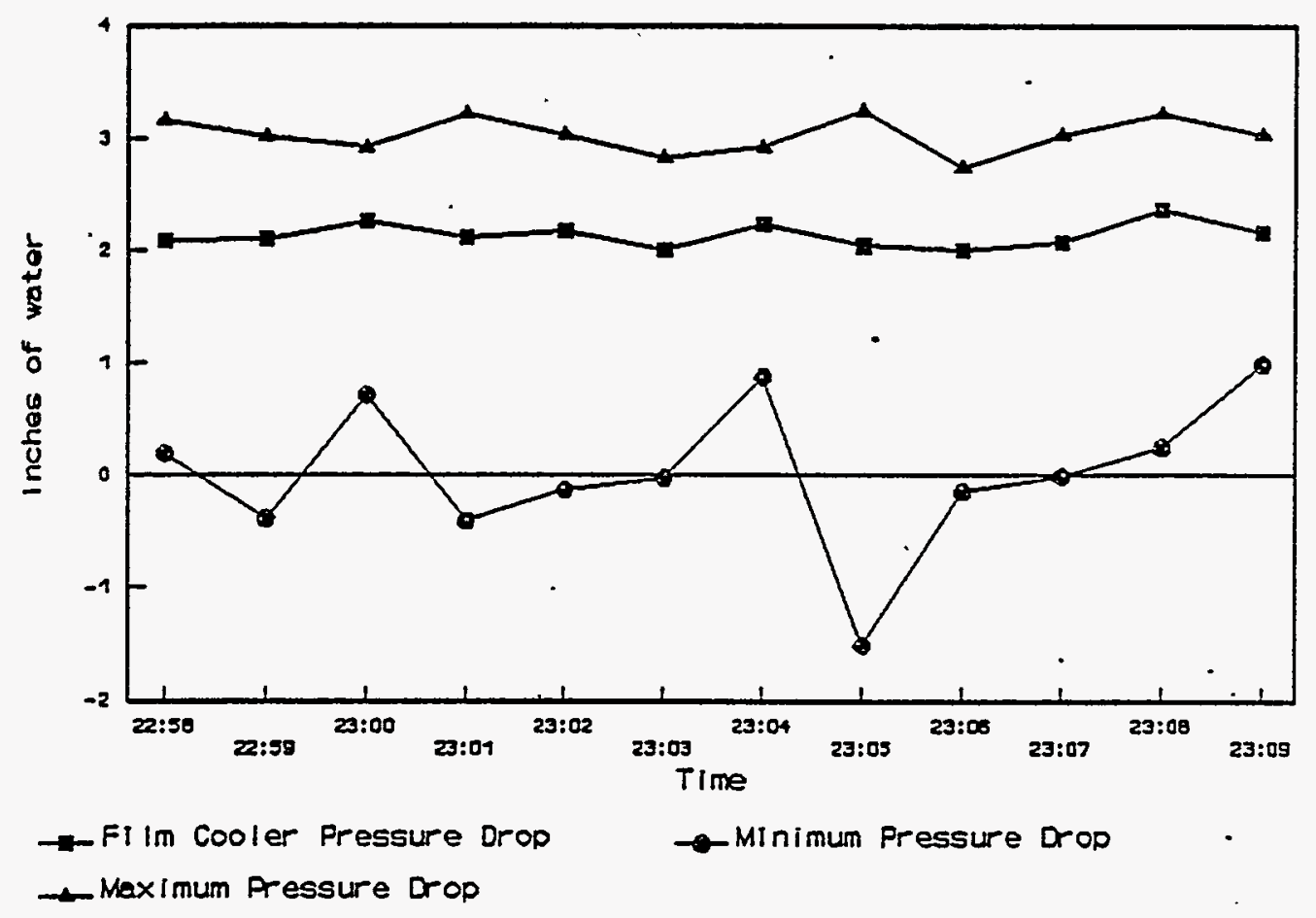

Figure 1.5: Normal Case Minimum, Maximum and Average Film Cooler Pressure Drop Recorded Each Minute. Averages over data collection period: Minimum Pressure Drop:0.22 in. WC Maximum Pressure Drop:2.96 in. WC Average Pressure Drop:2.14 in. WC 
3.1 Normal Case

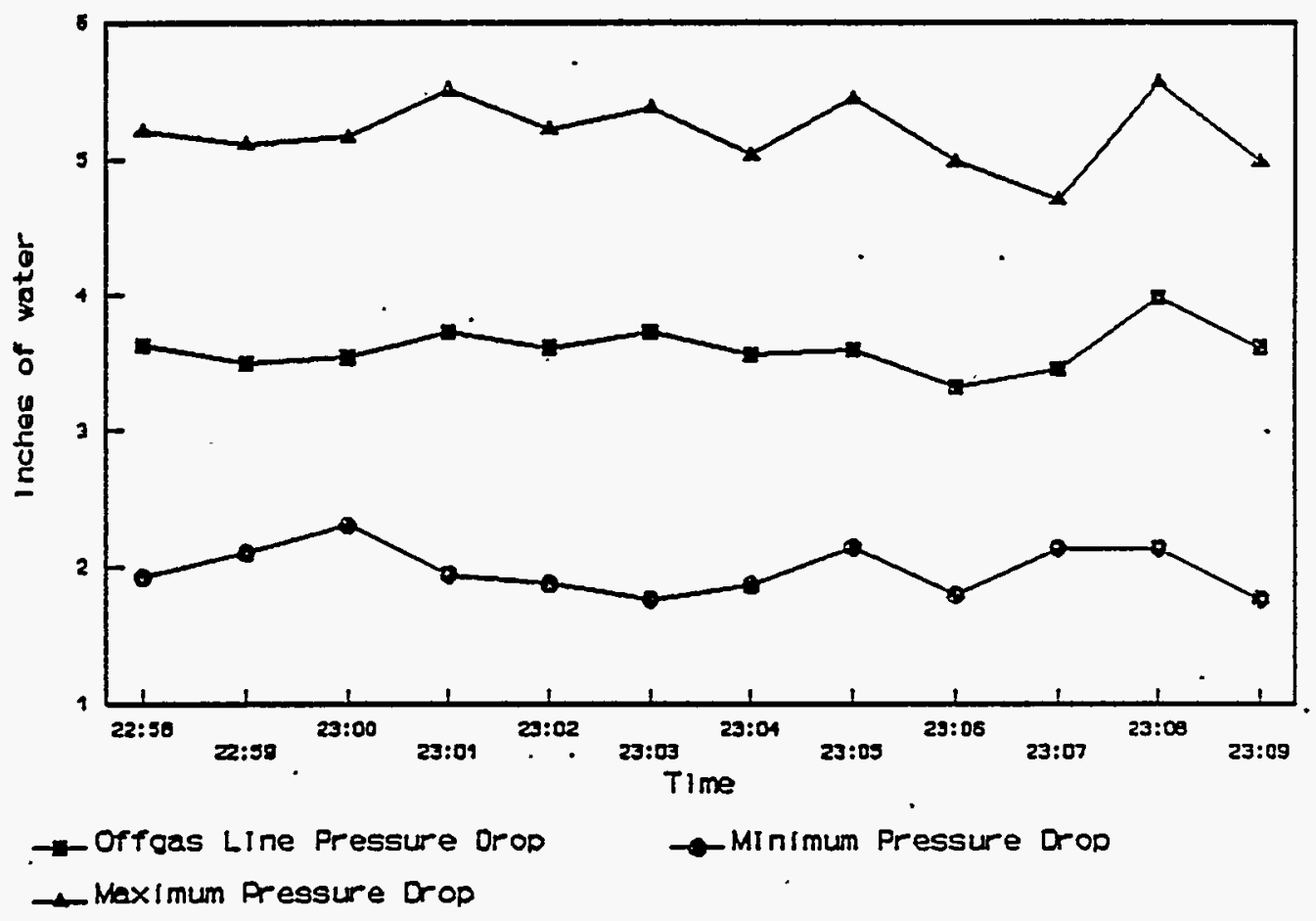

Figure 1.6: Normal Case Minimum, Maximum and Average Offgas Iine Pressure Drop: Averages over data collection period:

Minimum Pressure Drop: 2.07 in. WC

Maximum Pressure Drop: 5.36 in. WC

Average Pressure Drop: 3.68 in. WC 


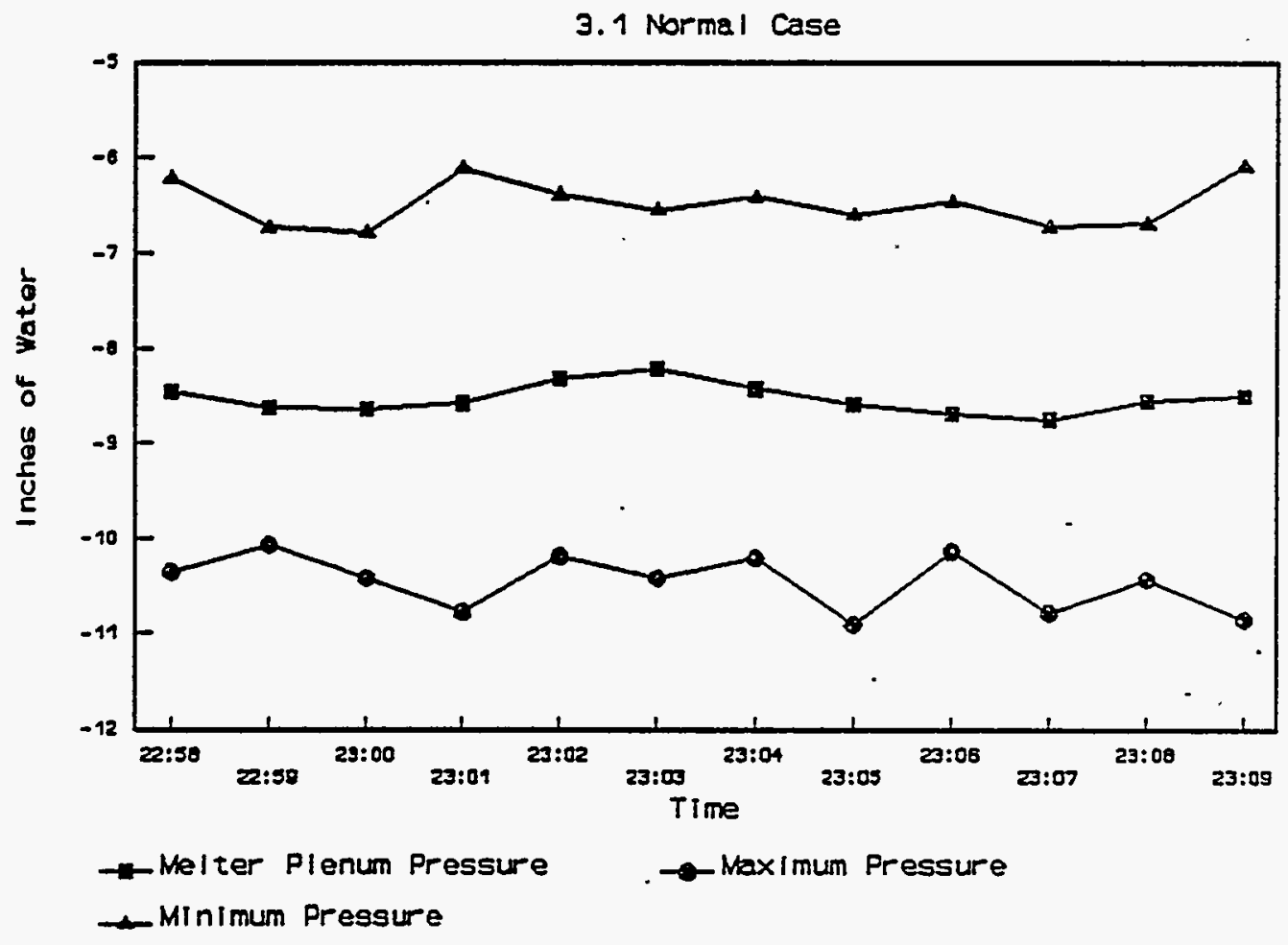

Figure 1.7: Normal Case Minimum, Maximum and Average Relative Melter Plenum Pressure. Averages over data collection period:

Minimum Pressure: -8.75 in. WC

Maximum Pressure: -4.61 in. WC

Average Pressure: -8.53 in. WC 


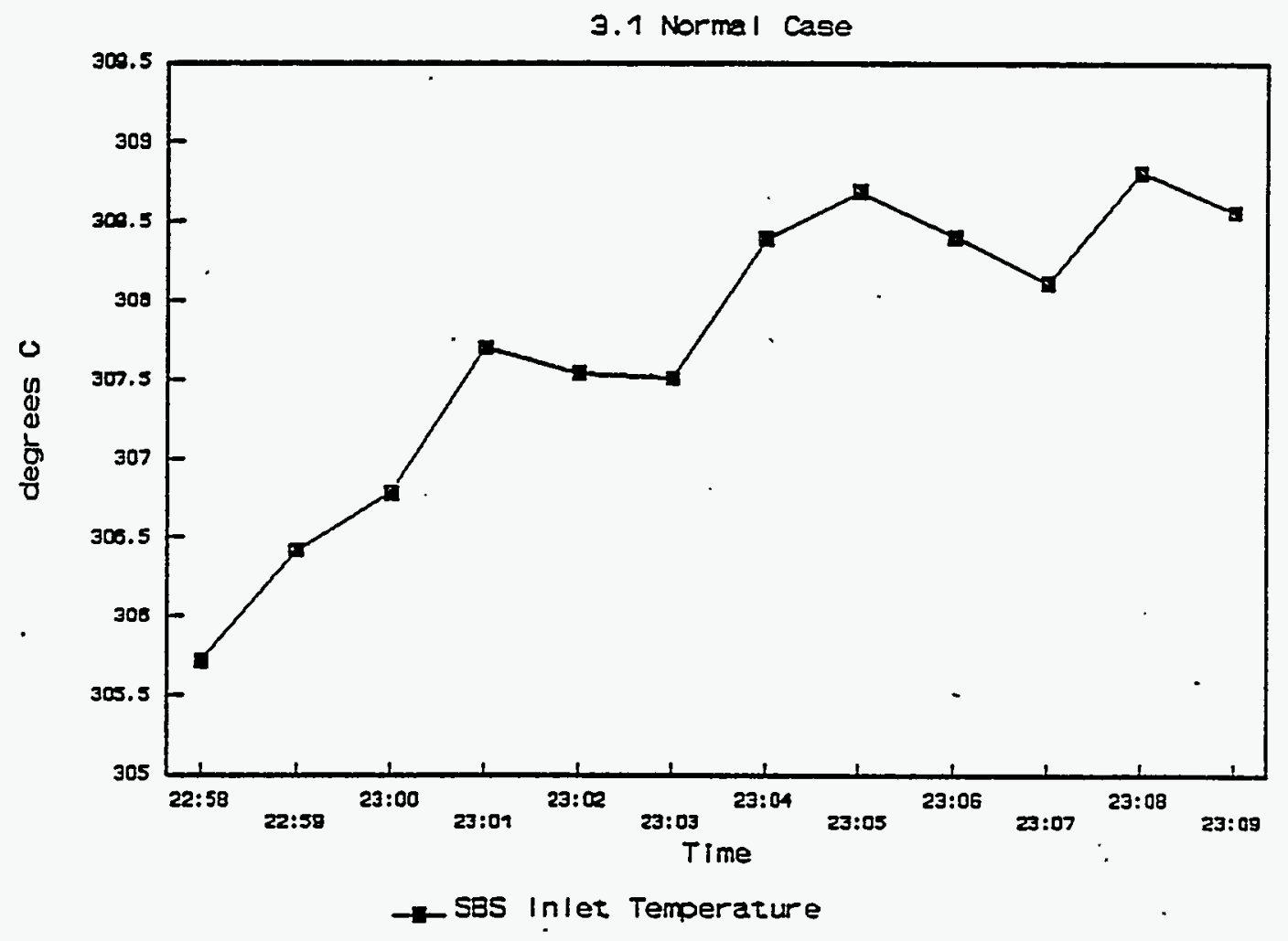

Figure 1.8: Normal Case Offgas Temperature at SBS Inlet. Average Temperature over period $307.7^{\circ} \mathrm{C}$. 
3.1 Normal Case

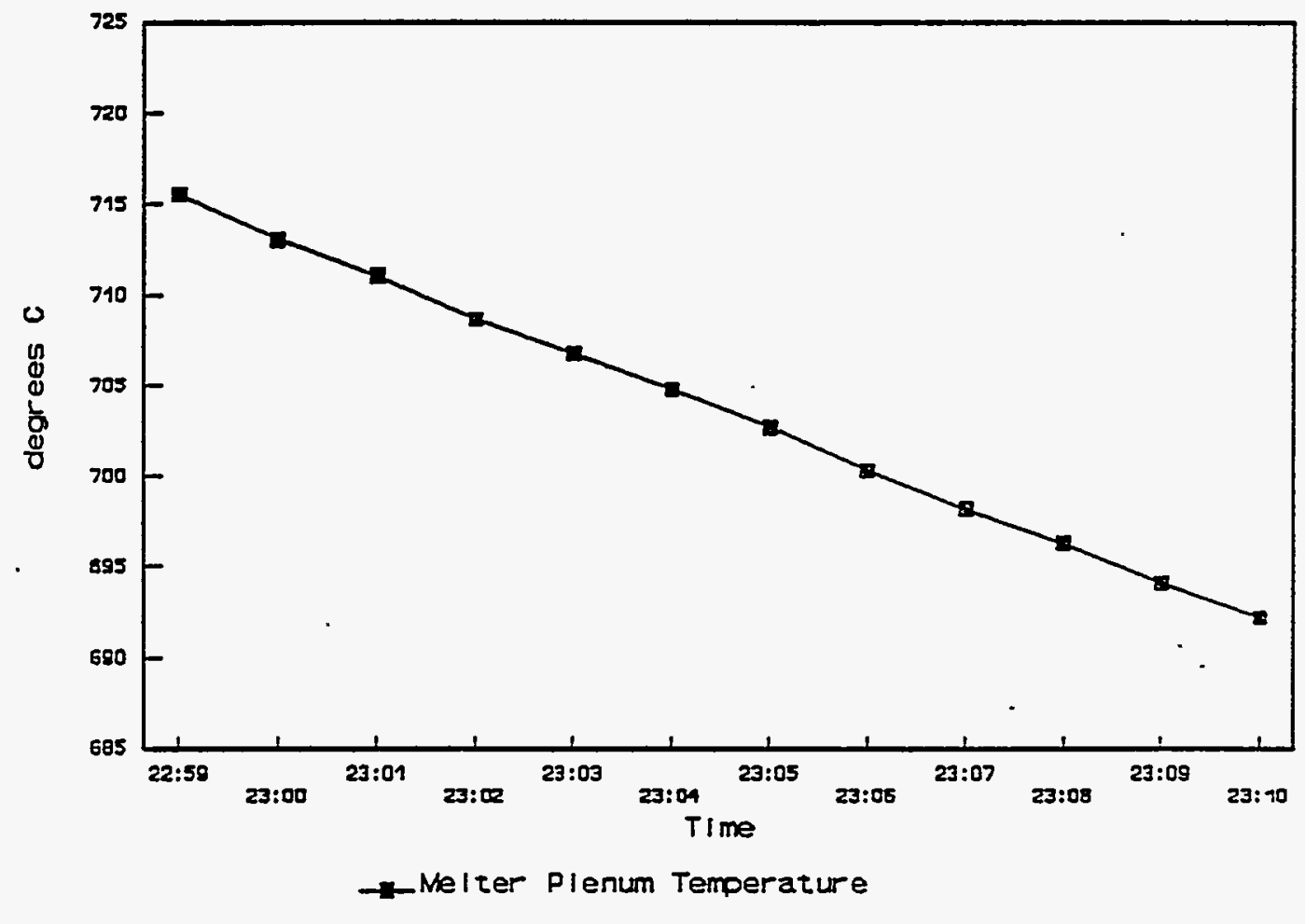

Figure 1.9: Normal Case Melter Plenum Temperature. Average value for melter plenum temperature was $705.74{ }^{\circ} \mathrm{C}$. 


\subsection{Maximum Plenum Temperature}

The variables recorded are the same as for the normal case described in section 1.1. The maximum plenum temperature case implemented an increase in plenum temperature to $1450^{\circ} \mathrm{F}$ and an increase in film cooler flow to 1.16 times the normal case. The data is summarized in Table 1.3 .

Table 1.3 Maximum Plenum Temperature Case Conditions

\begin{tabular}{|c|c|c|c|c|}
\hline - & Target & Average & $\begin{array}{l}\text { Avg } \\
\text { Max }\end{array}$ & $\begin{array}{l}\text { Avg } \\
\text { Min }\end{array}$ \\
\hline Melter Air Flow & 53 & $41^{1}$ & $-^{2}$ & - \\
\hline Film Cooler Air Flow $(1 \mathrm{~b} / \mathrm{h})$ & 901 & 908 & - & - \\
\hline Steam Injection $\quad(1 \mathrm{~b} / \mathrm{h})$ & 189 & 194 & - & - \\
\hline Plenum Pressure & - & 14.22 & 14.29 & 14.14 \\
\hline Plenum Temperature & 1450 & 1426 & - & - \\
\hline SBS Inlet Temperature & - & 587 & - & - \\
\hline Film Cooler DP & - & $2.1^{3}$ & 3.0 & 0.2 \\
\hline Offgas Iine DP & - & 3.8 & 5.4 & 2.1 \\
\hline
\end{tabular}

1

Flow calculated from SBS exit is 51 SCFM. The value in the Table is calculated from offgas flow and is believed to be more accurate.

2

- no data or no target established

3 The pressure drop is measured from the melter plenum to a location 6-in. past the downstream flange of the reamer brush section. Therefore, the pressure drop includes the film cooler as well as the section of offgas pipe on which the reamer brush will be mounted.

Comparison to Estimated Pressure Drops

Pressure drops through the film cooler and offgas line were estimated in a similar manner to that described for the normal case. The predicted film cooler pressure drop is 1.7 in. and the predicted offgas line pressure drop 2.8 in. The estimated values are slightly lower than the observed of 2.1 and 3.8 inches, respectively. 
Energy Balance over SBS During Operation

As a check on the process conditions an energy balance was performed in the same manner as was described in the normal case. For this case the error in the energy balance was 1.58 which is excellent agreement. This small error is less than the precision of measurement devices being used.

Comparison of Upstream and Downstream Non-Condensable Flowrates In addition, calculations were made of the air-only flow rate before and after the SBS to compare the readings. The average air-only flows were 239 scfm in the offgas line and 250 scfm exiting the SBS. Considering the fluctuations in the readings, and the assumptions required for the calculation such as no humidity in the melter inleakage, this is considered good agreement.

System Variables During Period of Interest Plots of the data for the period during which data was obtained are shown on the following pages in Figures 1.10 through 1.15. The data points plotted are one minute averages of the observed readings. These data points are then averaged to arrive at the values provided in Table 1.3. In general, single offgas flow and pressure measurements tended to fluctuate about a mean value with a frequency of approximately 3 hertz. This fluctuation is believed to originate in the SBS and is discussed further along with data need 3.2 . 


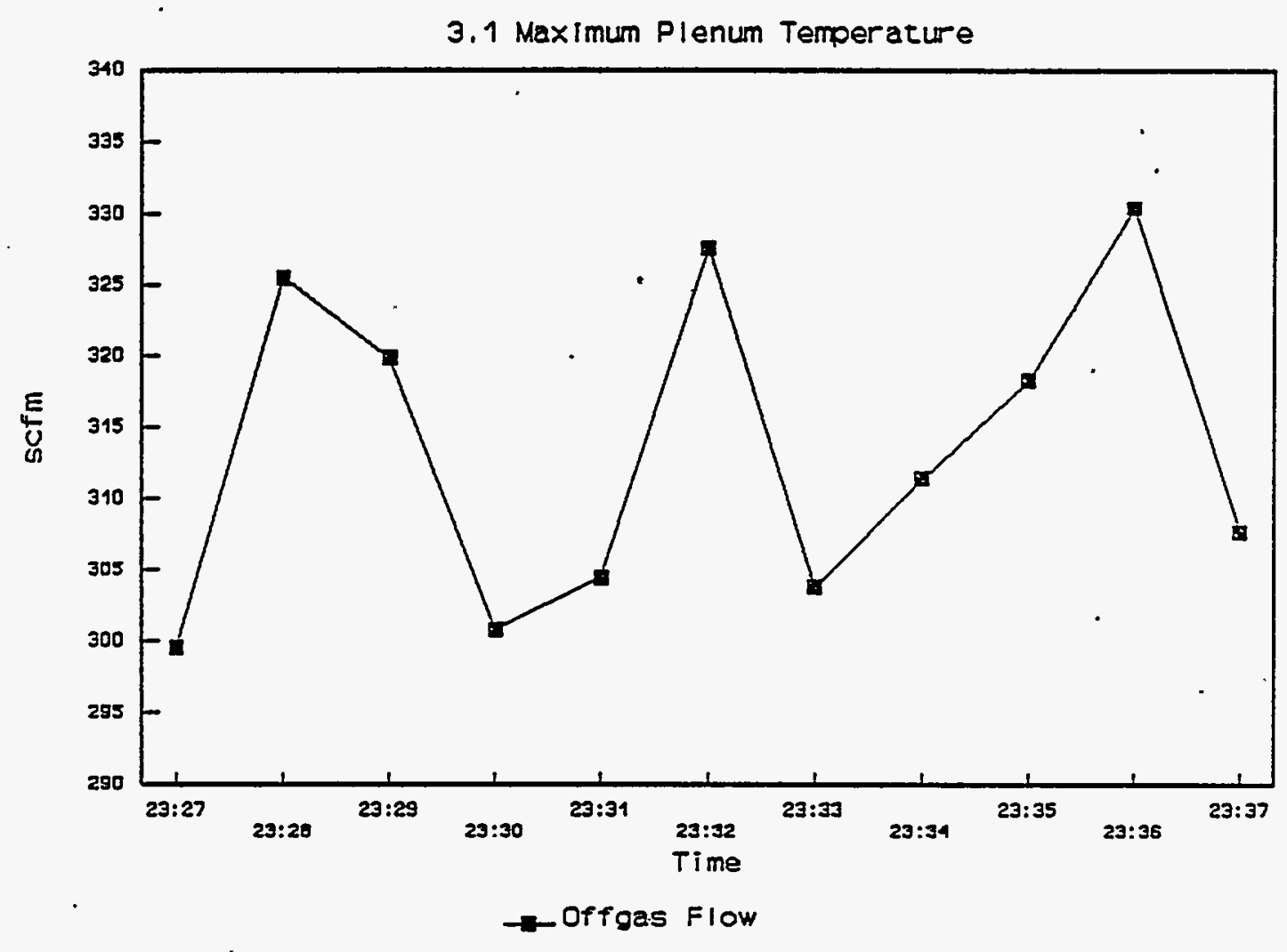

Figure 1.10: Total Offgas Flow Rate in the Offgas Jumper vs Time. Maximum plenum temperature case. Average over period was 314 scfm. 
3. 1 Maximum Plenum Temperature

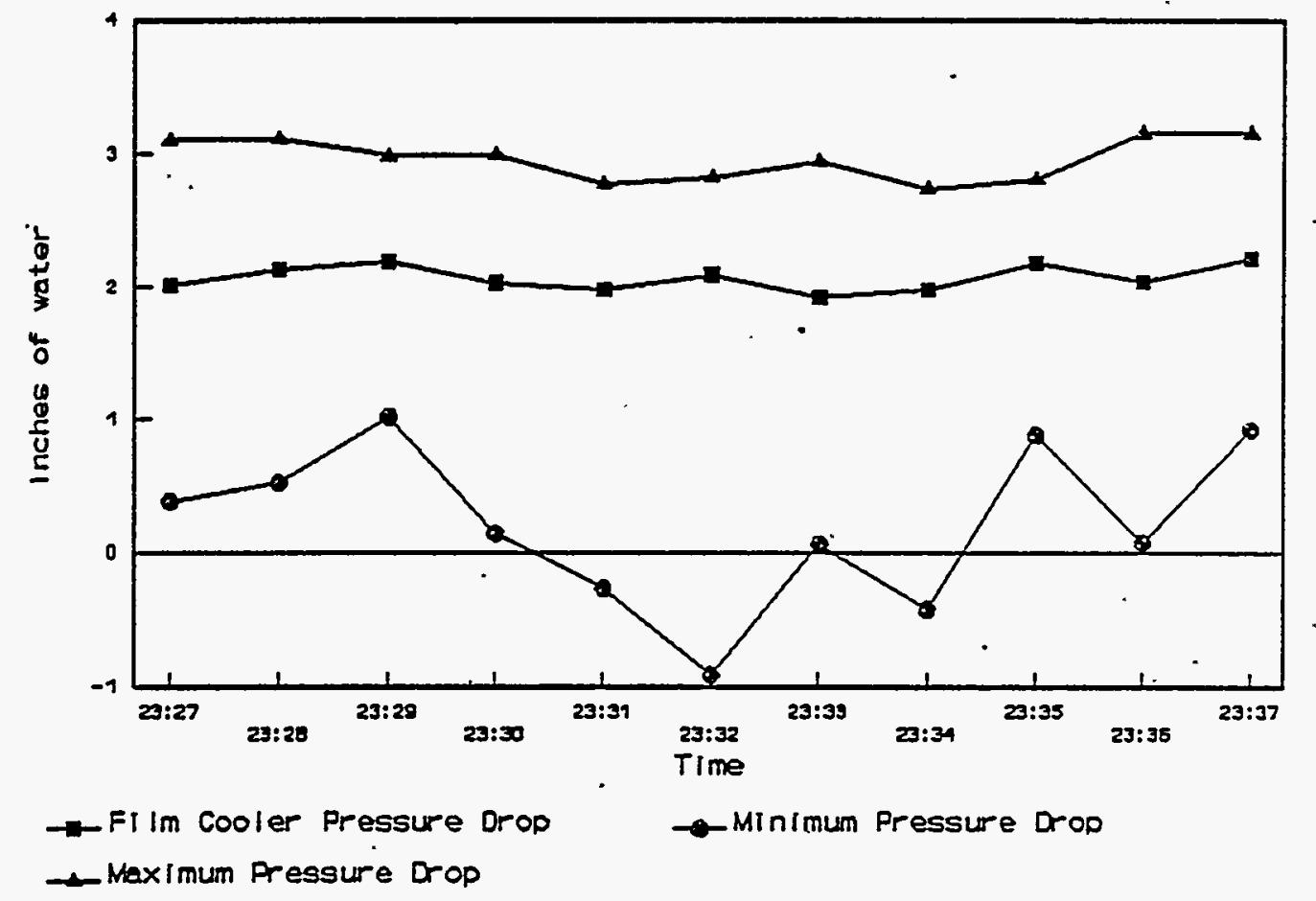

Figure 1.11: Maximum Plenum Temperature Case Minimum, Maximum and Average Film Cooler Pressure Drop. Averages over data collection period: Minimum Pressure Drop:0.03 in. WC Maximum Pressure Drop:3.03 in. WC Average Pressure Drop:2.07 in. WC. 


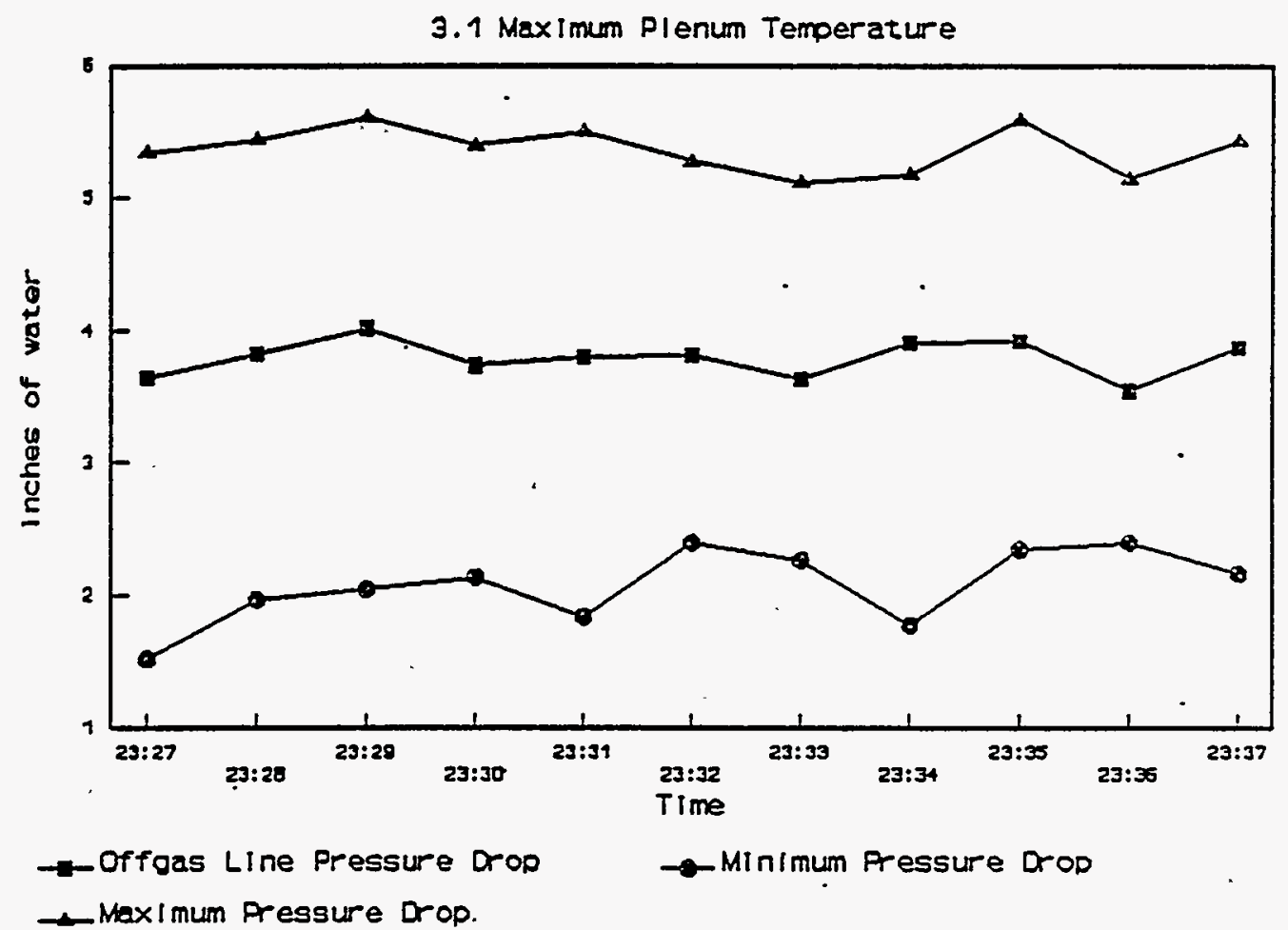

Figure 1.12: Maximum Plenum Temperature Case Minimum, Maximum and Average Offgas Line Pressure Drop. Average value over data collection period:

Offgas Line Pressure Drop 3.79 in. WC

Minimum Pressure Drop 1.98 in. WC

Maximum Pressure Drop 5.19 in. WC 


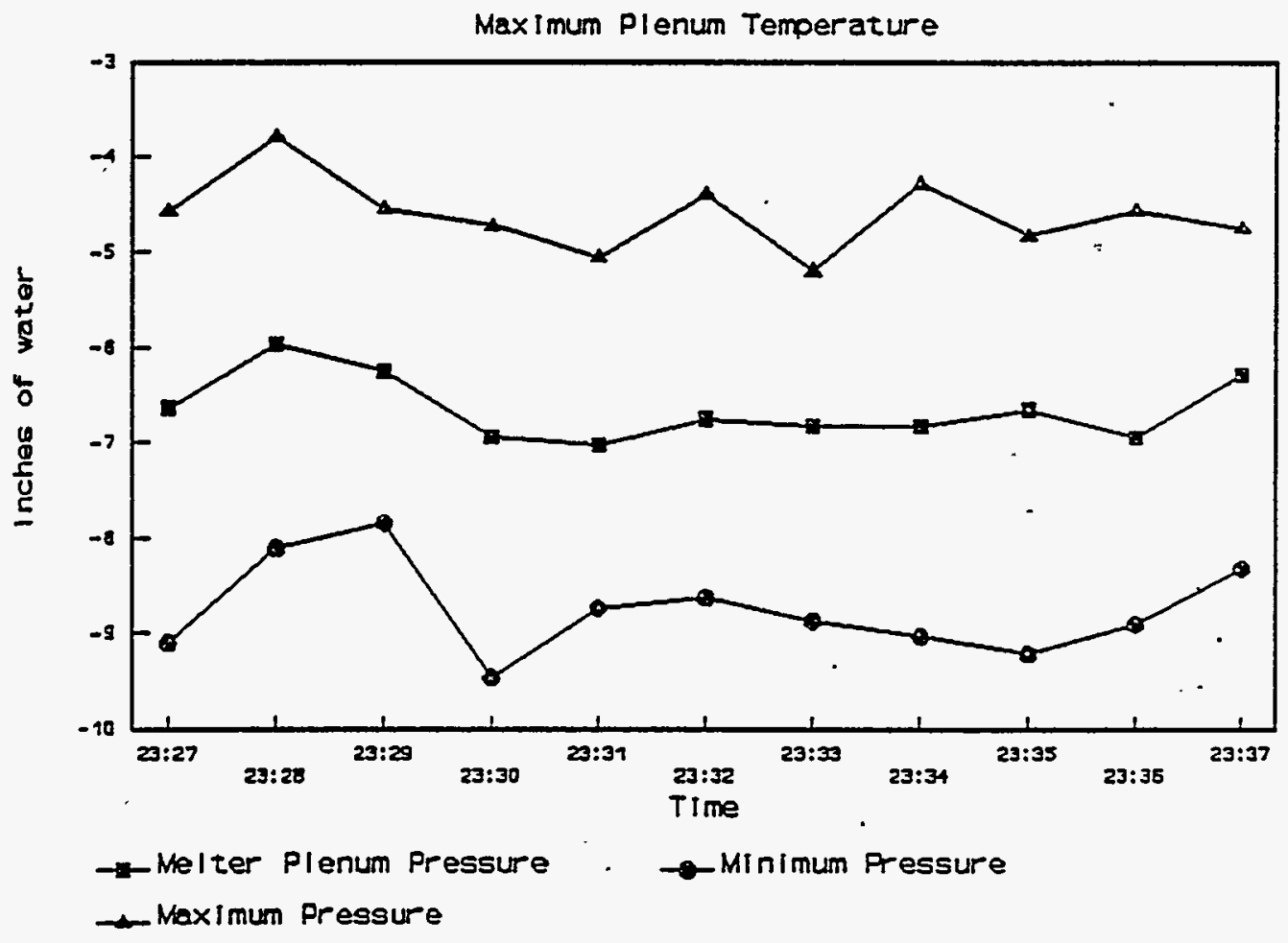

Figure 1.13: Maximum Plenum Temperature Case Minimum, Maximum and Average Relative Melter Plenum Pressure. Averages over data collection period:

Minimum Pressure: -10.47 in. WC

Maximum Pressure: -6.48 in. WC

Average Pressure: -6.65 in. WC 


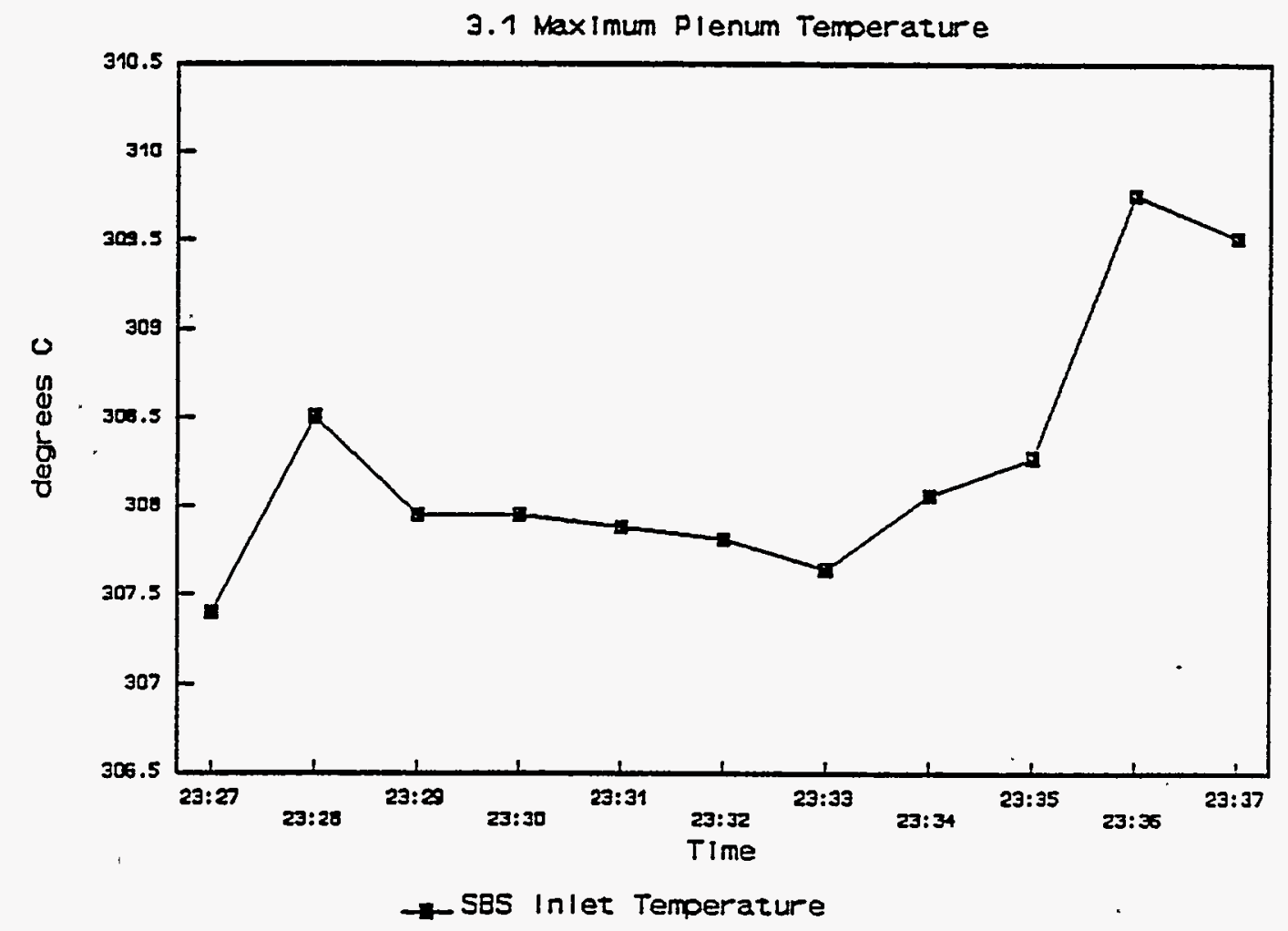

Figure 1.14: Maximum Plenum Temperature Case Offgas Temperature at SBS Inlet. Average temperature over period was $308.25^{\circ} \mathrm{F}$. 


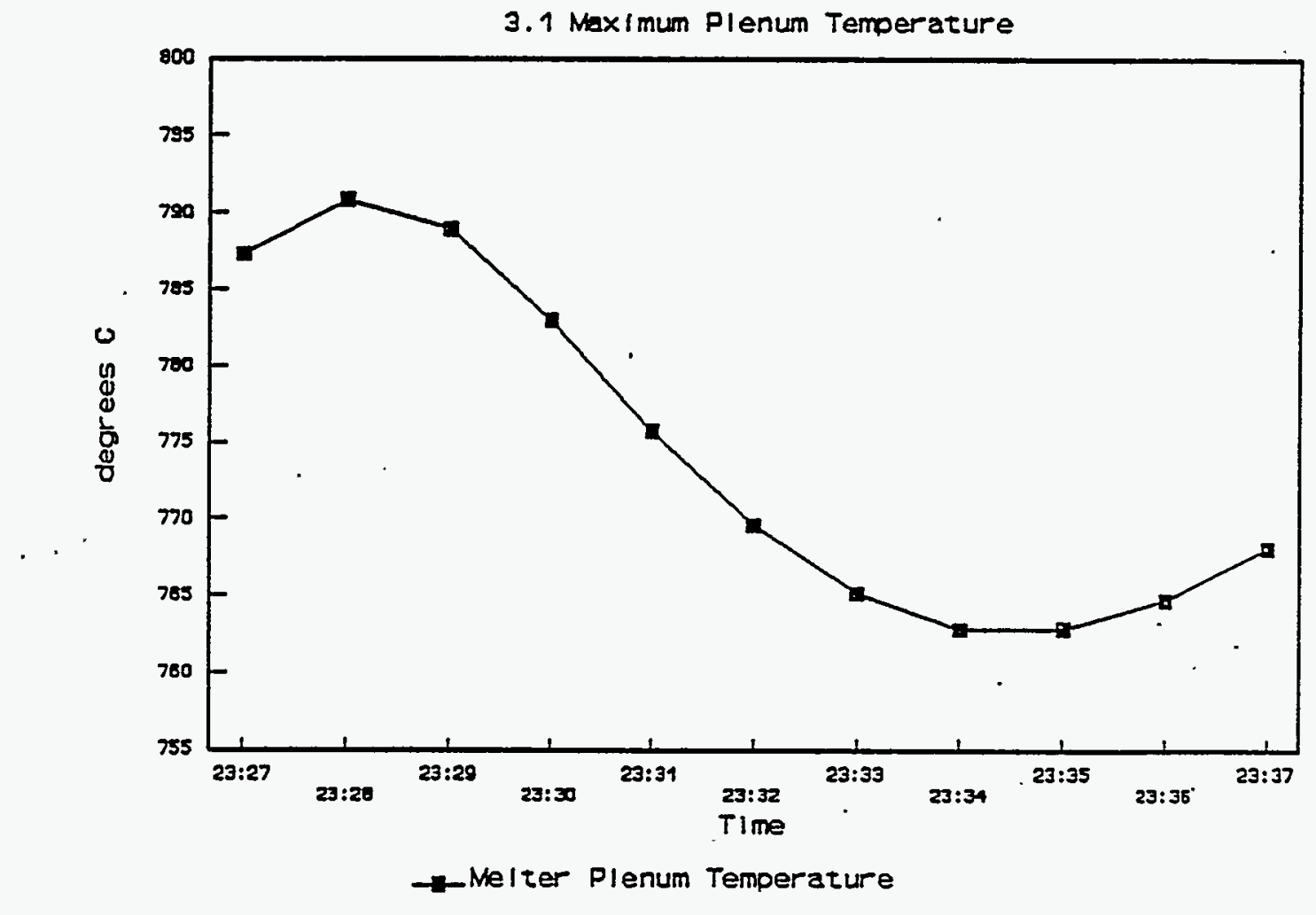

Figure 1.15: Melter Plenum Temperature for Maximum Plenum Temperature Case. The average over the period was $774^{\circ} \mathrm{F}$. 


\subsection{Steam Surge Case}

A steam surge in the melter is a transient event. However, the data shown below represents a $7 x^{3}$ steam surge under relatively steady conditions. The increased steam rate is maintained at a steady rate while data on pressure drops through the film cooler and off-gas line are measured. The requested data is shown in Table 1.4 .

Table 1.4 Steam Surge Case

\begin{tabular}{|c|c|c|c|c|}
\hline - & Target & Average & $\begin{array}{l}\text { Avg } \\
\text { Max }\end{array}$ & $\begin{array}{l}\text { Avg } \\
\text { Min }\end{array}$ \\
\hline Melter Air Flow & 56 & $58^{1}$ & -2 & - \\
\hline Film Cooler Air Flow $(\mathrm{lb} / \mathrm{h})$ & 777 & 762 & - & - \\
\hline Steam Injection $\quad(1 \mathrm{~b} / \mathrm{h})$ & 1285 & 1290. & $=$ & 二 \\
\hline Plenum Pressure & - & 14.26 & 14.32 & 14.20 \\
\hline Plenum Temperature & $<1330$ & 1043 & - & - \\
\hline SBS Inlet Temperature $\left({ }^{\circ} \mathrm{F}\right)$ & - & 686 & - & - \\
\hline Film Coolex DP & - & $11.6^{3}$ & 13.4 & 9.1 \\
\hline Offgas Iine DP & - & 14.4 & 17.1 & 12.2 \\
\hline
\end{tabular}

This flow was calculated from the SBS exit flowrate because calculation from the offgas line during steam surge conditions involves the subtraction of two large numbers to determine a small air inleakage term. Flow estimated using offgas jumper flow would be 11 SCFM but is believed to be less accurate.

no data or no target established

3

The pressure drop is measured from the melter plenum to a location 6-in. past the downstream flange of the reamer brush section. Therefore, the pressure drop includes the film cooler as well as the section of offgas pipe on which the reamer brush will be mounted.

3 The $7 \mathrm{X}$ steam surge includes a $3 \mathrm{X}$ increase in production of non-condensable gases in the melter. The $3 x$ in noncondensables does not apply to inleakage or air injection. 
Comparison to Estimated Pressure Drops

Pressure drops through the film cooler and offgas line were estimated in a similar manner to that described for the normal case. The predicted film cooler pressure drop is 6.7 in. and the predicted offgas line pressure drop 11.0 in. Both estimated values are lower than the values observed during testing, as depicted in Table 1.4.

Energy Balance over SBS During Operation

As a check on the process conditions an energy balance was performed in the same manner as was described in the normal case. For this case the error in the energy balance-was 8.18 which is higher than previous cases but not unreasonable. The energy balance indicates more energy being supplied to the SBS than was accounted for in cooling water, convective heat loss and temperature change.

Comparison of Upstream and Downstream Flowrates

In addition, calculations were made of the air-only flow rate before and after the SBS to compare the readings. The average air-only flows were $178 \mathrm{scfm}$ in the offgas line and 224 scfm exiting the SBS. This disagreement is somewhat greater than in previous cases and is likely a contributor to the error in the energy balance calculation. The reason for the poor agreement is not known.

\section{System Variables During Period of Interest}

- Plots of the data for the period during which data was obtained are shown on the following pages in Figures 1.16 through 1.21. The data points shown are 1 -minute averages. These values are then averaged to arrive at the values presented in Table 1.4 . Individual offgas flow and pressure measurements tended to fluctuate about a mean value with a frequency of approximately 3 hertz. This fluctuation is believed to originate in the SBS and is discussed further along with data need 3.2. 


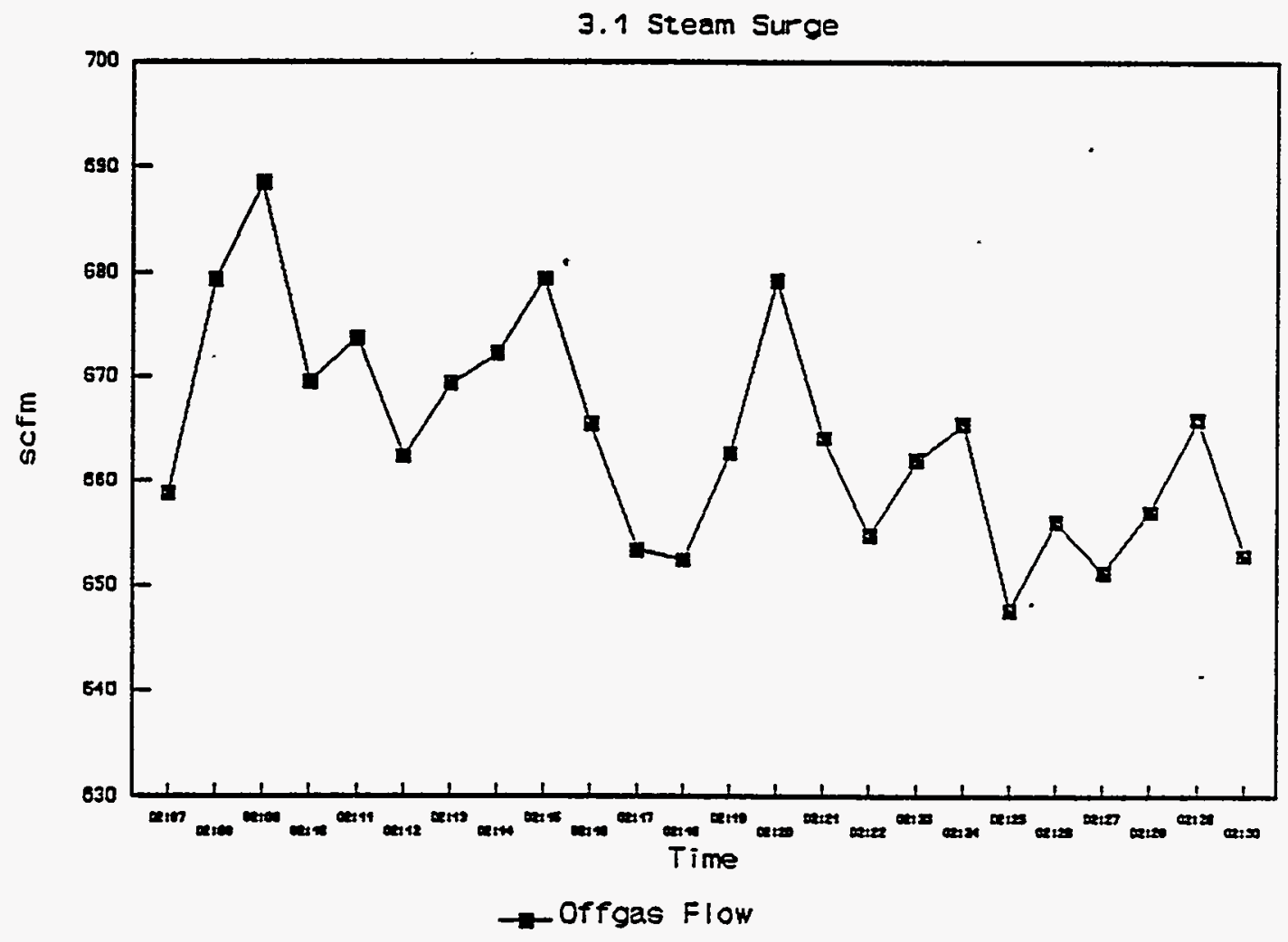

Figure 1.16: Total Offgas Flow Rate in the offgas Jumper for the Steam Surge Case. Average offgas flow was $664 \mathrm{scfm}$. 
3.1 Stoam Surgo

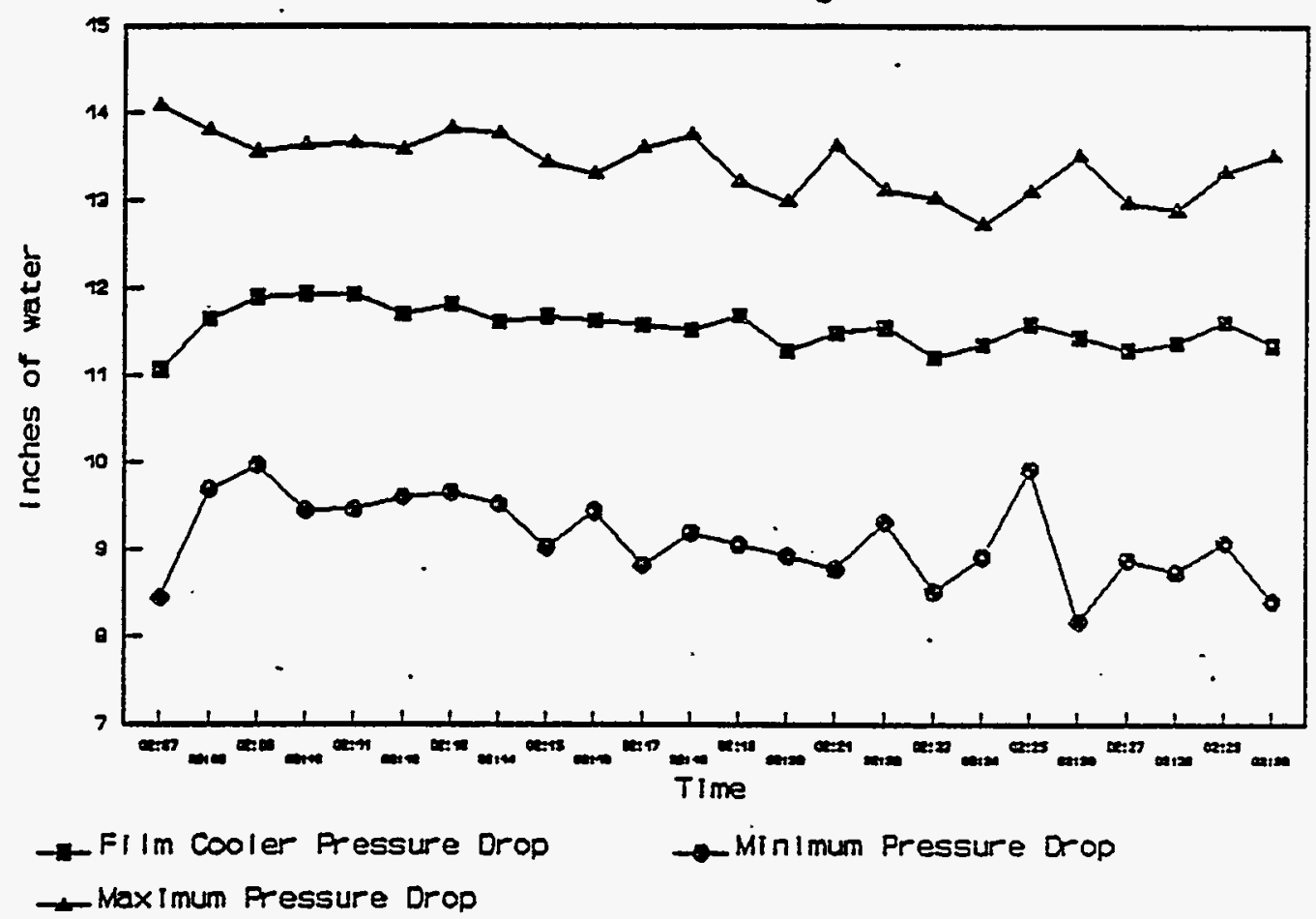

Figure 1.17: Steam Surge Case Minimum, Maximum and Average Film Cooler Pressure Drop. Averages over data collection period:

Minimum Pressure Drop: 9.1

Maximum Pressure Drop: 13.4

Average Pressure Drop: 11.6 


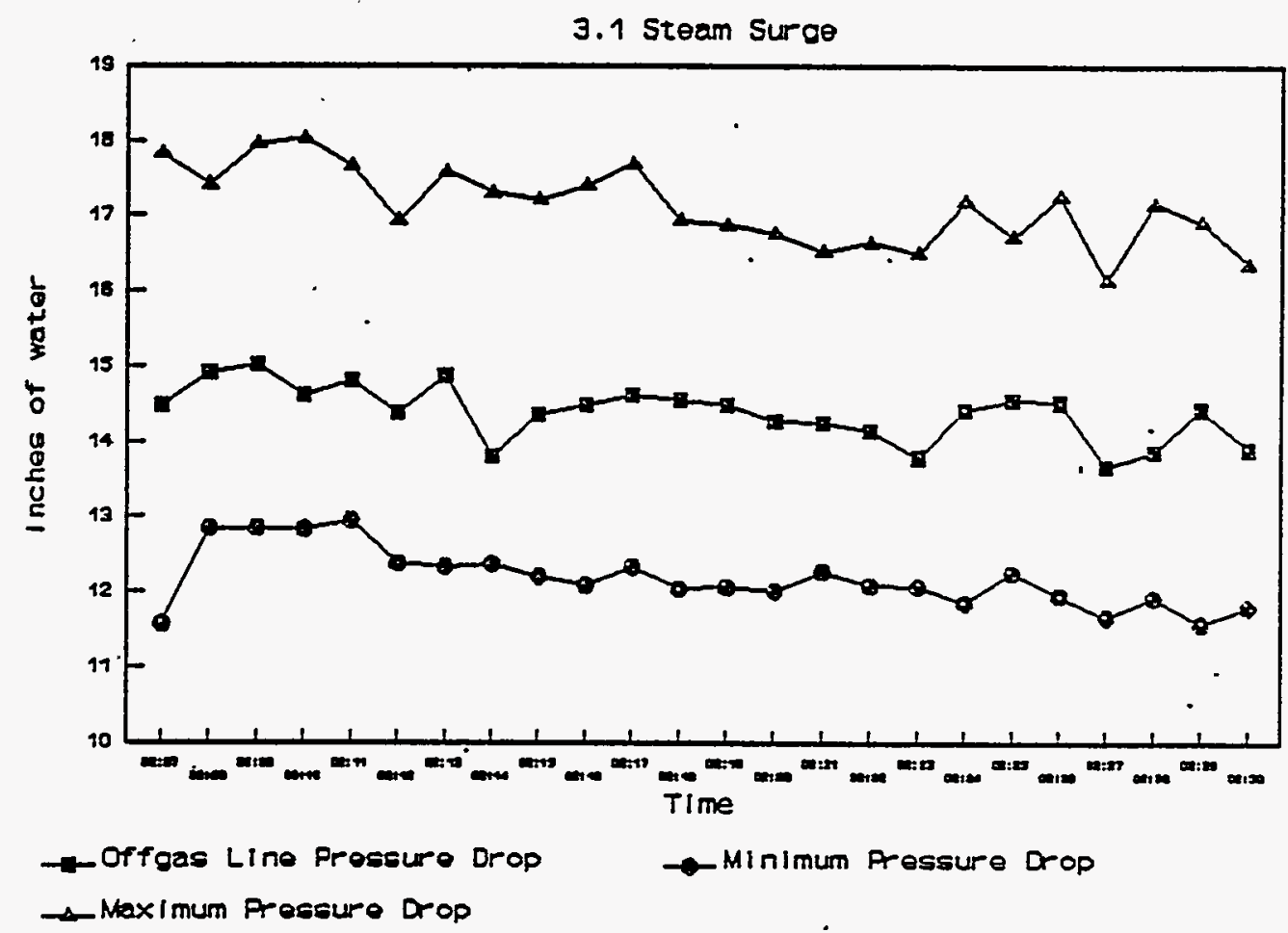

Figure 1.18: Steam Surge Case Minimum, Maximum and Average Offgas Line Pressure Drop. Average pressure drops over data collection period:

Minimum Pressure Drop:12.18

Maximum Pressure Drop:17.12

Average Pressure Drop:14.38 


\subsection{Steam Surgo}

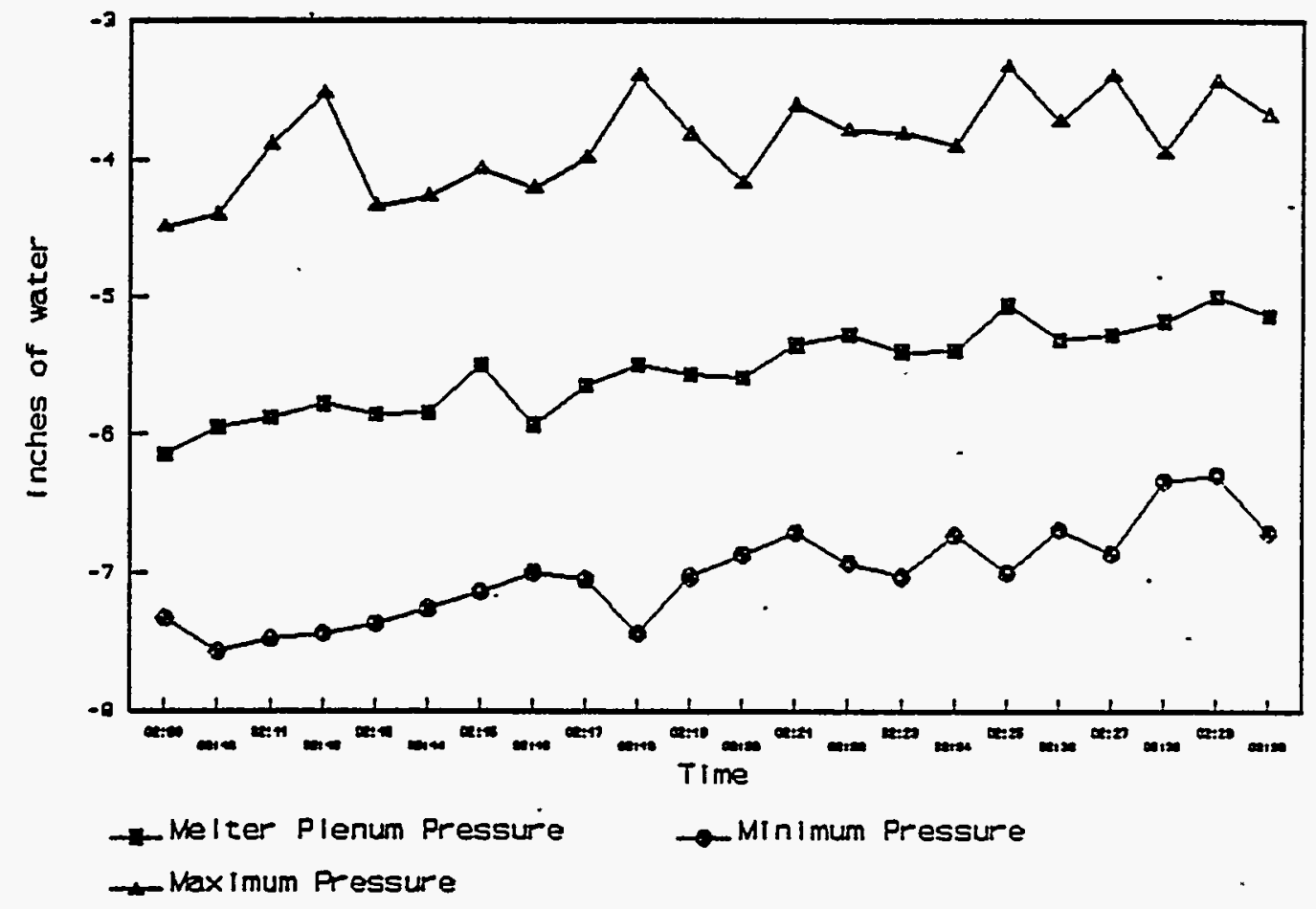

Figure 1.19: Steam Surge Case Minimum, Maximum and Average Relative Melter Plenum Pressure. Average values over data collection period:

Minimum Pressure: -7.09

Maximum Pressure: -3.77

Average Pressure:-5.53 
3.1 Steam Surge

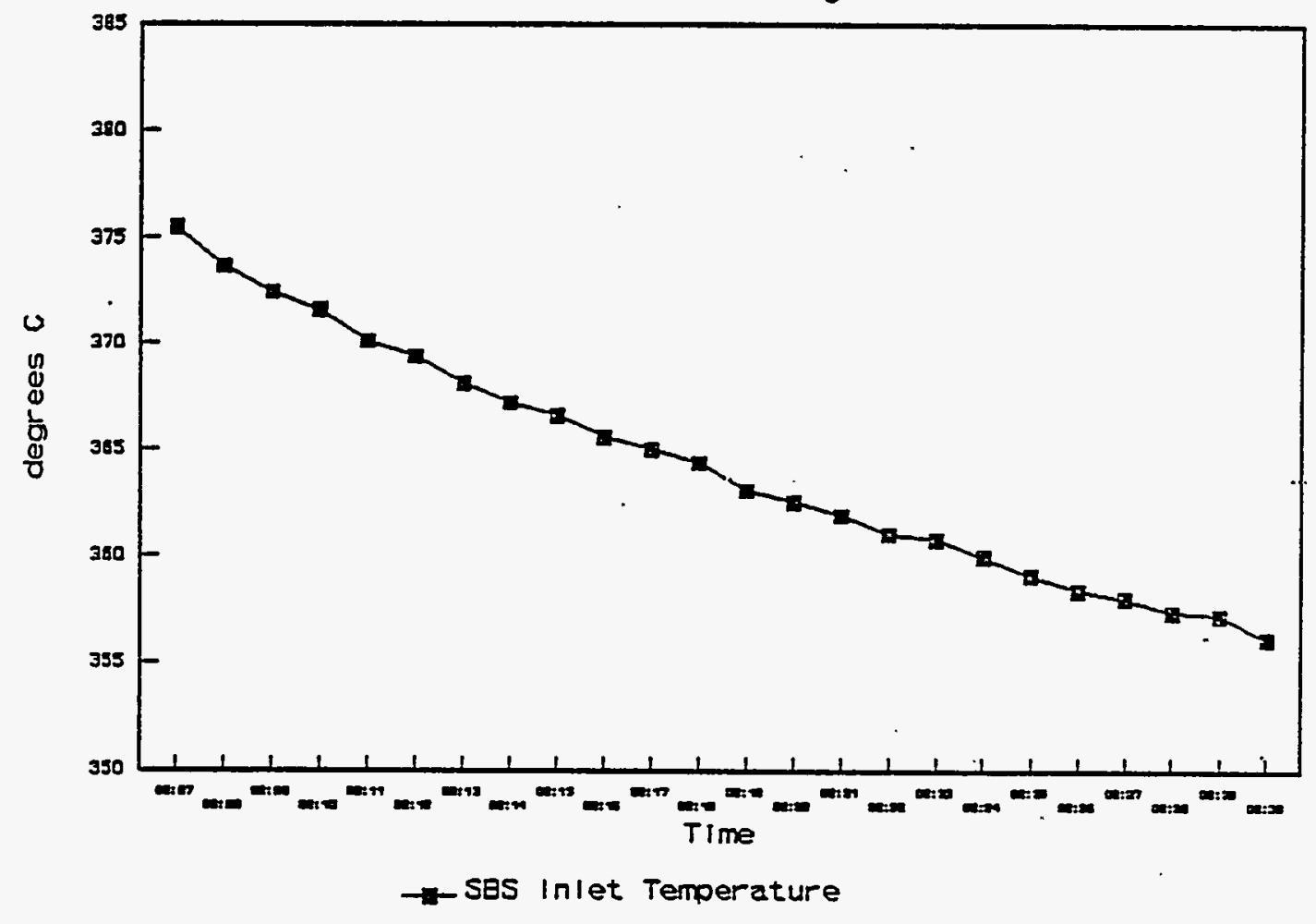

Figure 1.20: Offgas Temperature at SBS Inlet for Steam Surge Case. Average offgas temperature over. period was $364^{\circ} \mathrm{F}$. 


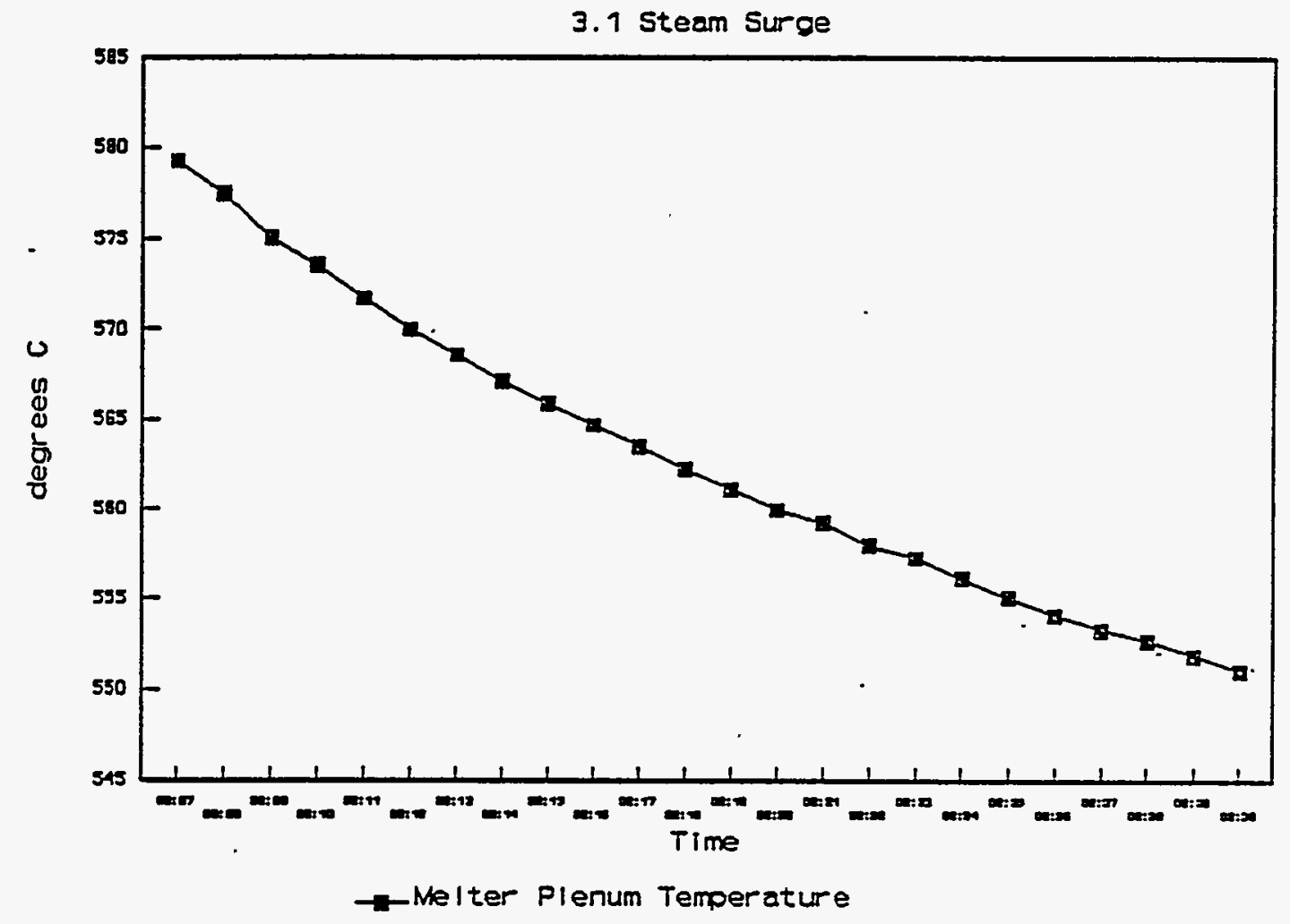

Figure 1.21: Steam Surge Case Melter Plenum Temperature. Average temperature over data collection period was $563^{\circ} \mathrm{F}$. 
1.4 Effect of Steam on Film Cooler/Offgas Line Pressure Drops

To better define the effect of steam on pressure drop through the film cooler and offgas line, the pressure drops were measured as the steam rate was incrementally increased between the normal case and the surge steam case. The conditions were maintained steady at each point for about 10 minutes before moving to the next condition. Table 1.5 summarizes the information obtained. The normal case and surge cases serve as the end points and are repeated here for completeness.

Table 1.5 Effect of Steam on Film Cooler and Offgas Iine Pressure Drops. Atmospheric pressure 29.43" $\mathrm{Hg}$.

\begin{tabular}{|c|c|c|c|c|c|c|}
\hline & $\begin{array}{l}\text { Normal } \\
\text { Case }\end{array}$ & & & & & $\begin{array}{l}\text { Steam } \\
\text { Surge }\end{array}$ \\
\hline $\begin{array}{l}\text { Steam Flow } \\
\text { (SCFM) }\end{array}$ & 68 & 130 & 206 & 280 & 344 & 453 \\
\hline $\begin{array}{l}\text { Air Flow } \\
\text { (SCFM) }\end{array}$ & 228 & 204 & 197 & 209 & 221 & 178 \\
\hline $\begin{array}{l}\text { Offgas Temperature } \\
\text { (ㄷ) }\end{array}$ & 308 & 335 & 332 & 376 & 391 & 363 \\
\hline $\begin{array}{l}\text { Film Cooler DP } \\
\text { Average } \quad \text { (" WC) }\end{array}$ & 2.1 & 3.2 & 4.8 & 6.7 & 9.5 & 11.6 \\
\hline $\begin{array}{l}\text { Film Cooler DP } \\
\text { Minimum }\end{array}$ & 0.0 & 0.6 & 2.5 & 4.3 & 7.2 & 9.1 \\
\hline $\begin{array}{l}\text { Film Cooler DP } \\
\text { Maximum }\end{array}$ & 3.0 & 4.2 & 6.4 & 8.8 & 11.3 & 13.4 \\
\hline $\begin{array}{l}\text { Offgas Line DP } \\
\text { Average (" WC) }\end{array}$ & 3.6 & 4.7 & 7.1 & 9.3 & 12.0 & 14.4 \\
\hline $\begin{array}{l}\text { Offgas Line } D P \\
\text { Minimum }(" W C)\end{array}$ & 2.0 & 2.5 & 4.8 & 6.8 & 9.6 & 12.2 \\
\hline $\begin{array}{l}\text { Offgas Line DP } \\
\text { Maximum }\end{array}$ & 5.2 & 6.9 & 9.7 & 12.1 & 14.4 & 17.1 \\
\hline
\end{tabular}

Data shown here was a repeat of the normal case data shown in Table 1.2. The values differ slightly. 
The steam flow represents the steam injected into the melter plenum. The air flow represents the air only (no steam) in the offgas line and includes film cooler air and inleakage to the melter. The film cooler air was not adjusted but drifted over a range of 166 to $177 \mathrm{scfm}$. Changes in inleakage air occurred as well which resulted in the variation in the air flow rate. The average values represent the average over 10 minutes or more of operation. The minimum and maximum pressure drops are the average over 10 minutes or more of the minimum or maximum reading obtained over each 1 minute interval.

The average, minimum and maximum pressure drops are plotted against total gas flowrate in Figures 1.22 and 1.23 . Because there was some variation in the air flowrate between the different data points the data was not plotted against the steam flowrate. However, the major difference in flowrate is due to the steam flowrate. 


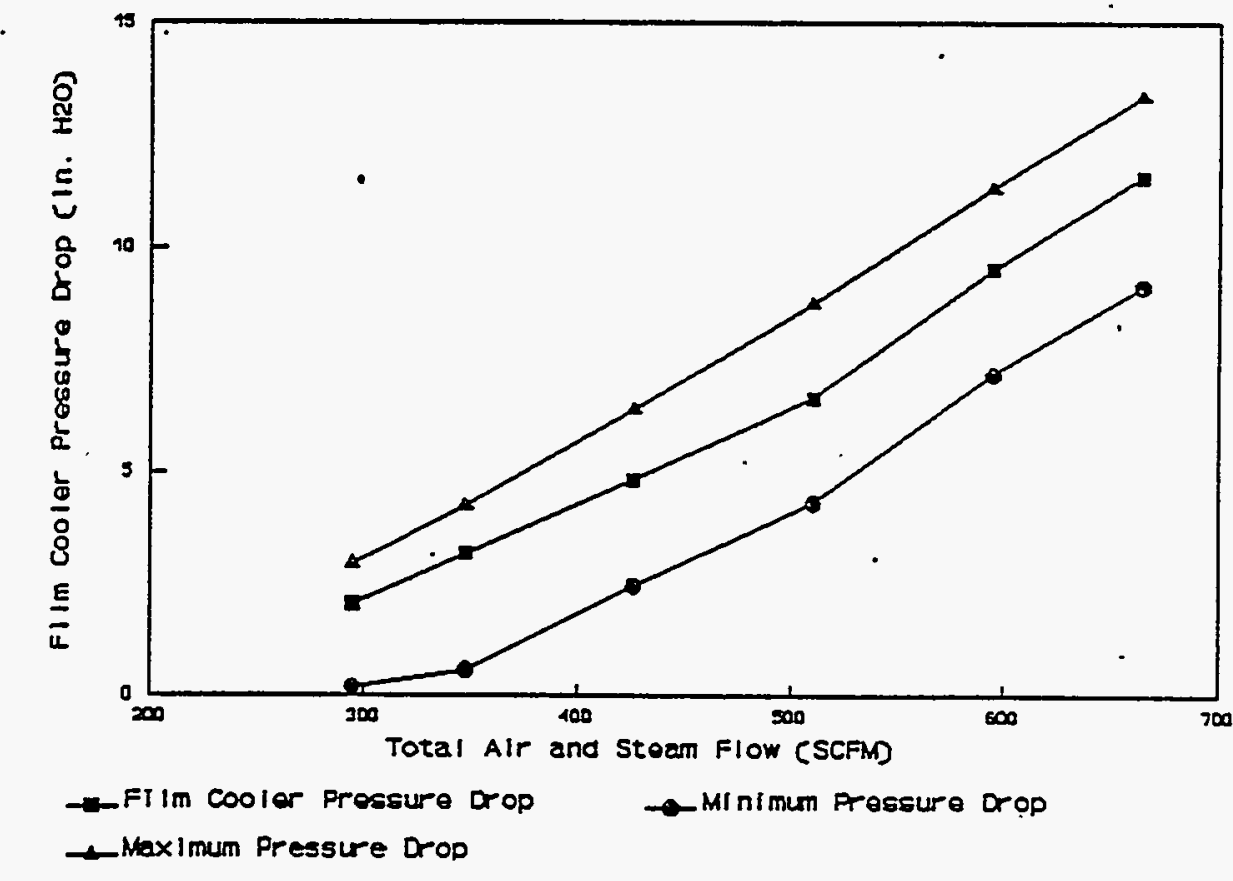

Figure 1.22. Film Cooler Pressure Drop vs. Flow In Offgas Line. Variation in flow is the result of increasing steam injection. 


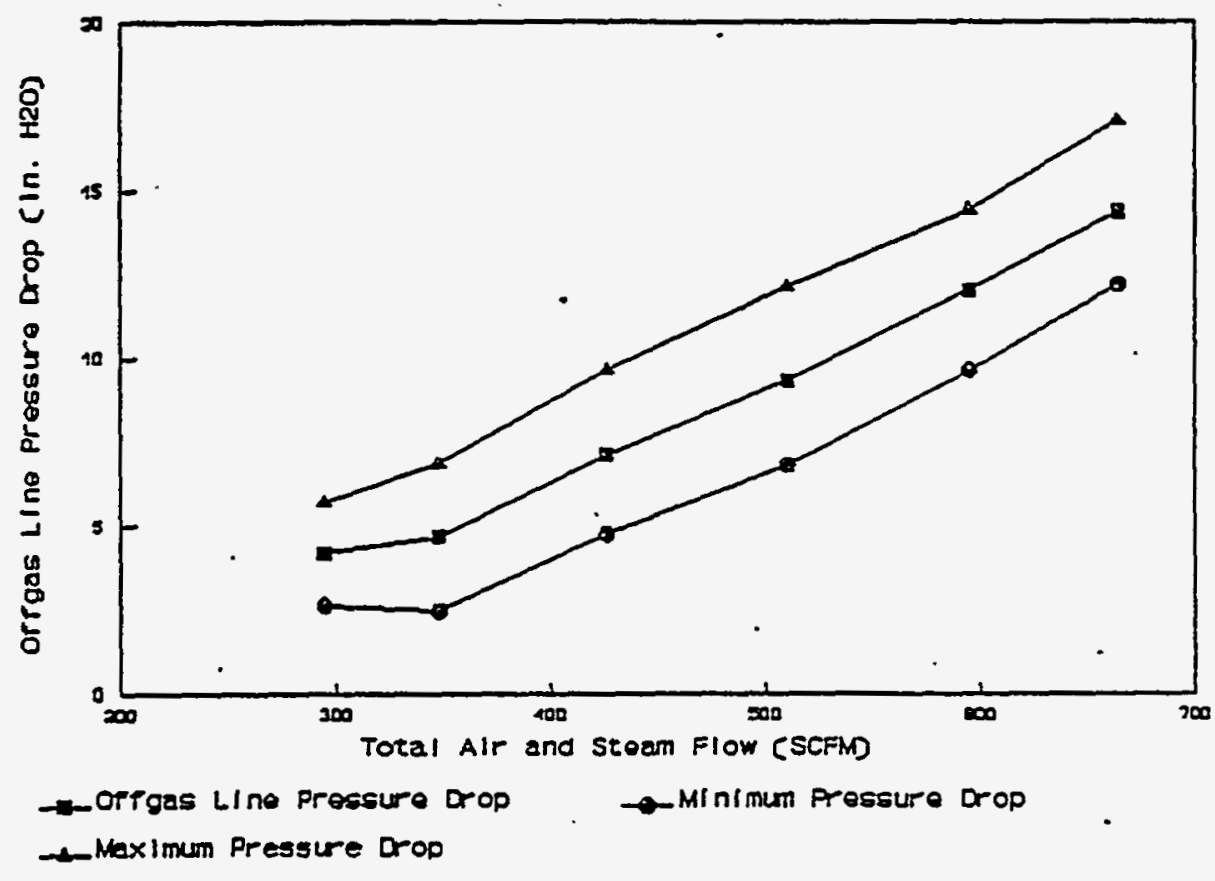

Figure 1.23. Offgas Iine Pressure Drop vs. Flow. Variation in flow is the result of increasing steam injection. 


\subsection{FLUOR DANIEL TECHNOLOGY NEED 3.2 SBS DATA}

This section addresses issues described in Fluor Data Needs 3.2a SBS Packing Selection, 3.2b and 3.2c Pressure Drop Data for SBS Distribution Plate and Packing, and $3.2 \mathrm{e}$ SBS Distribution Plate and Liquid Risers. Data need 3.2d SBS Sparge Ring Testing has béen previously reported.

The Fluor data need sheets for 3.2 specifically requested pressure drop, inlet and outlet temperatures and bed temperatures for a variety of process conditions. Two additional cases were requested by Fluor during a technology exchange. Also, requested was the decontamination factor (DF) for particles greater than and less than 1 micron through the SBS. DF information requires a melter aerosol source and could not be provided here. It will be provided along with IFCM-8 melter testing results.

Due to the very high flowrates requested a temporary blower was obtained and positioned next to the SBS to reduce pressure drop in the lines after the SBS. However, even with the temporary blower, not all of the conditions requested could be attained on the LFCM offgas system. The flows requested created an excessive pressure drop in the offgas jumper due to the 4 " line size. The case requesting $180 \mathrm{fpm}$ superficial velocity required that the offgas line be removed from the SBS inlet in order to attain the desired velocity. Because the offgas line was removed, steam could not be injected for cases with this velocity. However, the $180 \mathrm{fpm}$ case corresponds to the process vessel vent SBS in which high flows may be utilized to mitigate hydrogen generated during feed formating. Therefore, the behavior of steam at this flow is of less interest.

A. J. Schmidt, M. G. Herrington, Submerged Bed Scrubber Sediment Resuspension Testing for the Hanford Waste Vitrification Plant. November 1991. PHTD-K901 Part 1 of 3 . 


\subsection{Data Collection}

This section discusses those measurements included in this data need that were not discussed previously under Data need 3.1a. Some information on measurement of offgas flow is repeated here.

Offgas Flowrates Measurements of total offgas flow were made using dual pressure transducers connected to pitot tubes both before and after the SBS. The pressure readings from the dual transducers were averaged. Corrections for the average molecular weight of the gas due to the presence of steam were made for the pitot tube located downstream of the SBS. The resulting dry air flow was then used along with the steam injection rate to determine the correction required for the pitot tube in the offgas jumper. Humidity in air inleakage was ignored in the specific gravity correction to the flow in the offgas jumper. both cases measurements were taken. every 2 sec and one-minute averages were recorded.

\section{SBS Pressure Drop}

The SBS pressure drop was initially measured between a tap below the flange for connection of the offgas jumper to the SBS downcomer and a tap downstream of the chevron demister. A 140in. full-scale validyne pressure transducer was used.

In subsequent testing, the downstrean pressure tap was relocated to the SBS head space to measure only the downcomer and SBS bed in the pressure drop. These measurements were. made using a 55-in. full-scale pressure transducer. The pressure drop was sampled every 2 seconds and 1 -minute averages were recorded.

\section{Chevron Demister Pressure Drop}

The chevron demister is located at the SBS exit. A sketch of the demister is shown in Figure 2.1. Pressure drop measurements indicated that the contribution from the demister was significant at higher flowrates. Because of this, a relationship between flow and pressure drop was determined for the chevron demister. This relationship allows previously collected SBS pressure drop data to be corrected for the demister pressure drop. A 55-in. full-scale Validyne pressure transducer was used to develop this relationship. The pressure taps were located in the SBS head space, and downstream of the chevron demister.

\section{Inlet SBS Temperature}

The inlet offgas temperature was measured using a type $K$ thermocouple inserted into the SBS downcomer below the flange connecting it to the offgas line. . Readings were taken every 2 sec and one minute averages were recorded. 


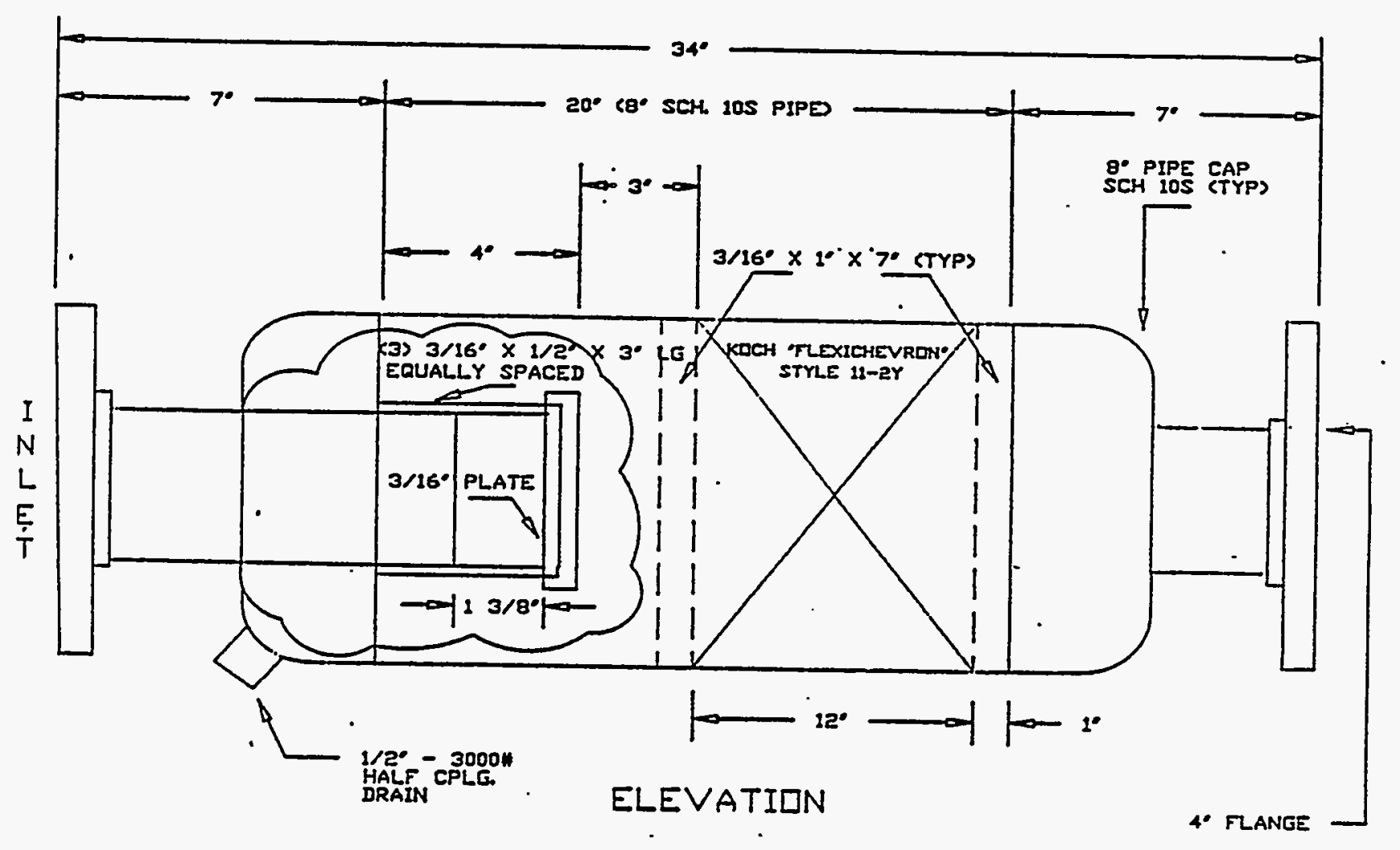

Figure 2.1 Chevron Demister 
Outlet SBS Temperature

The outlet offgas temperature was measured using a type $R$ thermocouple inserted into the offgas line downstream of the chevron demister. Readings were taken every 2 seconds and 1minute averages were recorded.

\section{SBS Bed Temperatures}

Temperatures in the SBS bed were measured by a total of 27 type $J$ thermocouples within the SBS bed. A conceptual sketch of the location of the thermocouples is shown in Figure 2.2.

Readings were taken every 2 seconds and one-minute averages were recorded for each thermocouple.

\section{SBS Annulus Temperatures}

Temperatures of the SBS scrub solution in the annulus space outside the bed were measured at four selected locations. The measurements were made using sheathed 100-ohm platinum wire RTDs positioned above and below the cooling coils on the east and west side of the vessel. The location is shown schematically in Figure 2.2. The resistance was measured manually during testing using a Fluke multimeter. The precision of the temperature measurement taken this way was $0.25^{\circ} \mathrm{C}$. These measurements were taken above and below the cooling coils. From the temperature difference of the scrub liquid passing over the cooling coils, the circulation velocity of the scrub solution was calculated.

\section{Cooling Water Temperatures}

Cooling water temperatures were measured at the entrance and exit of the cooling water using RTDs identical to those described above under SBS Annulus Temperatures. The location is shown schematically in Figure 2.2. These measurements were used-in calculation of the liquid circulation velocity as well as for a conducting energy balances over the system.

\section{Cooling Water Flow Measurement}

A Brooks water flowmeter was used to measure cooling water flowrates to the SBS. A calibration curve was generated for the flowmeter for the 4-20 gpm range. The relationship was linear but the readings deviated approximately 128 from the actual flow. Readings were corrected before use based on this calibration. 

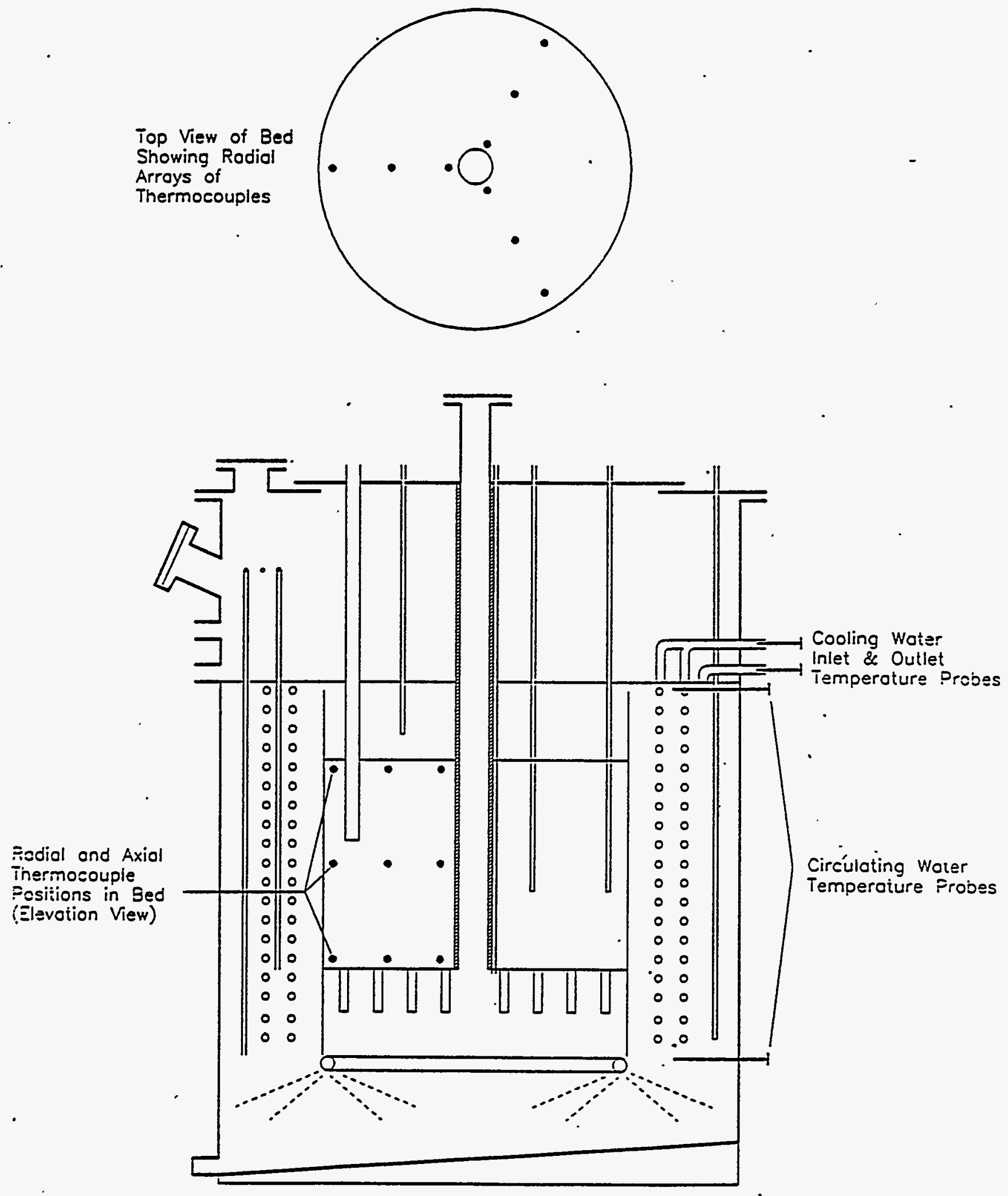

Figure 2.2 Locations of Type $J$ Thermocouples and RTD Elements in SBS. 
Overflow Measurements

In order to determine the volume of liquid displaced by gas at various flowrates, the amount of water that overflowed was measured. This information was used to estimate void volumes within the SBS bed. Before startup, the SBS was filled to the upper drain level. The drain line from the SBS was rerouted and dipped into a carboy with calibrated level marks on the side. The overflow occurred over a period of time, with most of the overflow draining in the first few minutes after gas flow was initiated or increased. Overflow continued, however, due to additional water continuing to splash up into the overflow drain line. This flow decreased with time. The end measurement was taken when the overflow rate fell below $1.5 \mathrm{I} / \mathrm{min}$. 


\subsection{Summary of Requested Data}

Table 2.1 shows the table included in the Fluor data need sheets for 3.2 filled in with the requested information. Decontamination factors are not available at this time and will be provided at the conclusion of IFCM melter testing. The initial Fluor data need sheet indicated normal and surge steam flows of 35 and $245 \mathrm{lb} / \mathrm{h} \mathrm{ft}$ respectively. These values were inconsistent with rates specified in other data needs and were changed to 29 and $201 \mathrm{Ib} / \mathrm{h} \mathrm{ft}^{2}$ after discussions with Fluor. The reason that the surge steam flow is not exactly 7 times the normal flow is that the normal flow includes humidity in the inleakage which is not multiplied by 7 to determine the surge flow. To determine inleakage moisture Fluor assumed that the cell air was saturated at $30^{\circ} \mathrm{C}$. The environment of the LFCM is much lower humidity. Therefore, in applying the steam rates the full indicated steam rate is injected to the melter plenum. The humidity in the inleakage air is neglected.

The initially requested data for 180 fpm superficial air flow through the SBS with normal and steam surge cases was removed from the test matrix.. Instead a single case with air only was tested. The data was requested to evaluate the possibility of using high air flows to mitigate hydrogen concentrations from feed formating operations. Steam surge data is not be applicable to the process vessel vent system. In addition, the requested flows are beyond the capability of the current system. The pressure drop across the process piping becomes excessive at these flowrates.

Data for two additional conditions were requested by Fluor during the 1/15/92 technology exchange meeting. The $51.2 \mathrm{sfpm}$ air flows with normal and surge steam conditions are shown along with the initially requested data in Table 2.1. A repeat of the surge case was performed to determine the degree of variability that might be expected in performing testing on different days due to changes in offgas temperature or other variables. Lower offgas temperatures result in lower pressure drops in the SBS downcomer for the same superficial velocity based on exit conditions.

The conditions specified as $51.2 \mathrm{sfpm}$ air/29 $\mathrm{lb} / \mathrm{h} \mathrm{ft}^{2}$ steam represent an evaporating condition in the SBS. The water leaving the SBS in the saturated exit gas is greater than the steam supplied from the melter. If utilized in HWV, this condition will require a makeup water supply to the SBS.

A summary of the data collected for the individual test conditions is provided in Appendix A. 
Table 2.1 Fluor Daniel Technology Need Data Sheet

Technical Need Item Nos. 3.2a, 3.2b, 3.2c and 3.2e - Data sheet for MOG SBS Testing $1 / 2$ inch Ceramic Intalox Saddles

\begin{tabular}{|c|c|c|c|c|c|c|c|c|}
\hline $\begin{array}{c}\text { Air } \\
\text { Superficial } \\
\text { Velocity. } \\
\text { fpm }\end{array}$ & $\begin{array}{l}\text { Steam Flpw } \\
\text { lb/hr } \mathrm{ft}^{2}\end{array}$ & $\begin{array}{l}\text { SBS } \\
\text { Press } \\
\text { Drop } \\
\text { "WC }\end{array}$ & $\begin{array}{c}\text { DF } \\
\text { under } \\
1 \\
\text { micron } \\
\end{array}$ & $\begin{array}{c}\text { DF } \\
\text { over } \\
1 \\
\text { micron } \\
\end{array}$ & $\begin{array}{c}\text { Gàs } \\
\text { Inlet } \\
\text { Temp } \\
{ }_{\mathbf{F}} \\
\end{array}$ & $\begin{array}{c}\text { Gas } \\
\text { outlef } \\
\text { Temp } \\
{ }_{\mathrm{O}}\end{array}$ & $\underset{\substack{\text { Temp } \\
\text { Temp }}}{\text { SBd }}$ & Case \\
\hline $60 \quad(62.8)$ & $29 \quad(27.3)$ & 41.3 & 9 & 8 & 692.6 & 124.3 & 126.5 & Normal \\
\hline $62 \quad(80.9)$ & $201(199.3)$ & 46.3 & 9 & 9 & 657.7 & 122.2 & 125.4 & Surge \\
\hline $120(124.6)$ & $29 \quad(29.4)$ & 41.4 & g & $\mathbf{g}$ & 695.7 & 124.5 & 126.7 & Normal \\
\hline $123(111.7)$ & $201(201.3)$ & 44.7 & $g$ & $\mathbf{g}$ & 555.6 & 120.3 & 122.7 & Surge \\
\hline $180(148.8)$ & $(0)$ & 42.4 & 9 & 9 & 400.8 & 122.5 & 124.3 & No $s t m$ \\
\hline $180^{c}(178.1)$ & $0 \quad(0)$ & 50.2 & 9 & $g$ & 90.0 & 68.5 & 69.1 & No stm \\
\hline $51.2^{d}(53.6)$ & $29 \quad(26.8)$ & 42.7 & 9 & 9 & 600.3 & 125.6 & 126.7 & Normal \\
\hline $51.2^{d}(54.3)$ & 201 (189.1) & 43.1 & 9 & 8 & 579.4 & 154.8 & 157.3 & Surge \\
\hline $51.2^{d}(62.4)$ & $201(199.5)$ & 45.2 & 9 & 9 & 601.9 & 116.8 & 119.3 & Surge \\
\hline
\end{tabular}

- Reference conditions are SBS outlet conditions unless indicated otherwise. Requested flow rates are shown, actual flow rates achieved are given in parenthesis.

b HEME was bypassed in all cases.

c A repeat of the requested data in the previous line except that the' offgas line was removed and air was be drawn directly into SBS, rather than through the melter. The 
SBS pressure drop was configured to be measured without the effect of the demister. Correction is made for entrance effect of disconnected offgas line.

In Standard fpm, $14.7 \mathrm{psia}$ and $60^{\circ} \mathrm{F}$. This flow rate provides the Fluor requested superficial velocity of $0.26 \mathrm{~m} / \mathrm{s}$.

Target mass flow rates are shown, with actual flow rates given in parenthesis.

The estimated pressure drop across the chevron demister has been subtracted from this value. The estimated pressure drop at the entrance flange to the SBS has also been subtracted when the offgas line was not in place.

No data. DF measurements require feeding of the melter.

Temperature measured downstream of the chevron demister.

Temperatures are collected from 27 thermocouples within the bed. SBS target temperature is $125^{\circ} \mathrm{F}$. SBS temperatures are uniform, indicating instant quenching and even dispersal of the incoming gas. 


\subsection{Demister Pressure Drop Relationship}

The chevron demister is located at the SBS exit. Initial data was collected measuring the pressure drop across the SBS including the demister. At high flow rates the demister pressure drop is a significant fraction of the total sBS pressure drop. A correlation was developed to allow prediction of the demister pressure drop as a function of flow. This correlation is then used in the next section to subtract the effect of the demister from the total sBs pressure drop.

The pressure drop across the demister was measured as a function of flowrate. Figure 2.3 shows the demister headloss in thousands of feet of working fluid vs. the velocity in the 4-in. schedule 10 pipe in which it is installed. The data is then fit to the equation:

$$
\begin{aligned}
& h_{1}=k v^{2} / 2 g \\
& \text { Where } h_{1}=\text { head loss } \\
& v=\text { velocity in } 4 \text {-in. schedule } 10 \text { pipe } \\
& g \text { = gravitational constant, } 32 \mathrm{ft} / \mathrm{s}^{2} \\
& \overrightarrow{\mathrm{K}} \text { = resistance coefficient }
\end{aligned}
$$

The data was fit to determine the correlation using both the gas exit conditions and the average of the gas conditions at the inlet and outlet. When correlated using the exit conditions the resistance coefficient was 6.091 with a standard deviation of $0.074(1.218)$. When correlated to the average of the inlet and exit offgas conditions, the resistance coefficient was 7.23 with a standard deviation of 0.081 ( $1.11 \%$ ).

Although the fit using average gas conditions is slightly better, data collected previously was corrected using the correlation for gas conditions at the demister exit. This was done because the final offgas pressure was measured directly in most cases making it a more convenient and reliable reading on which to base the demister pressure drop estimate. 


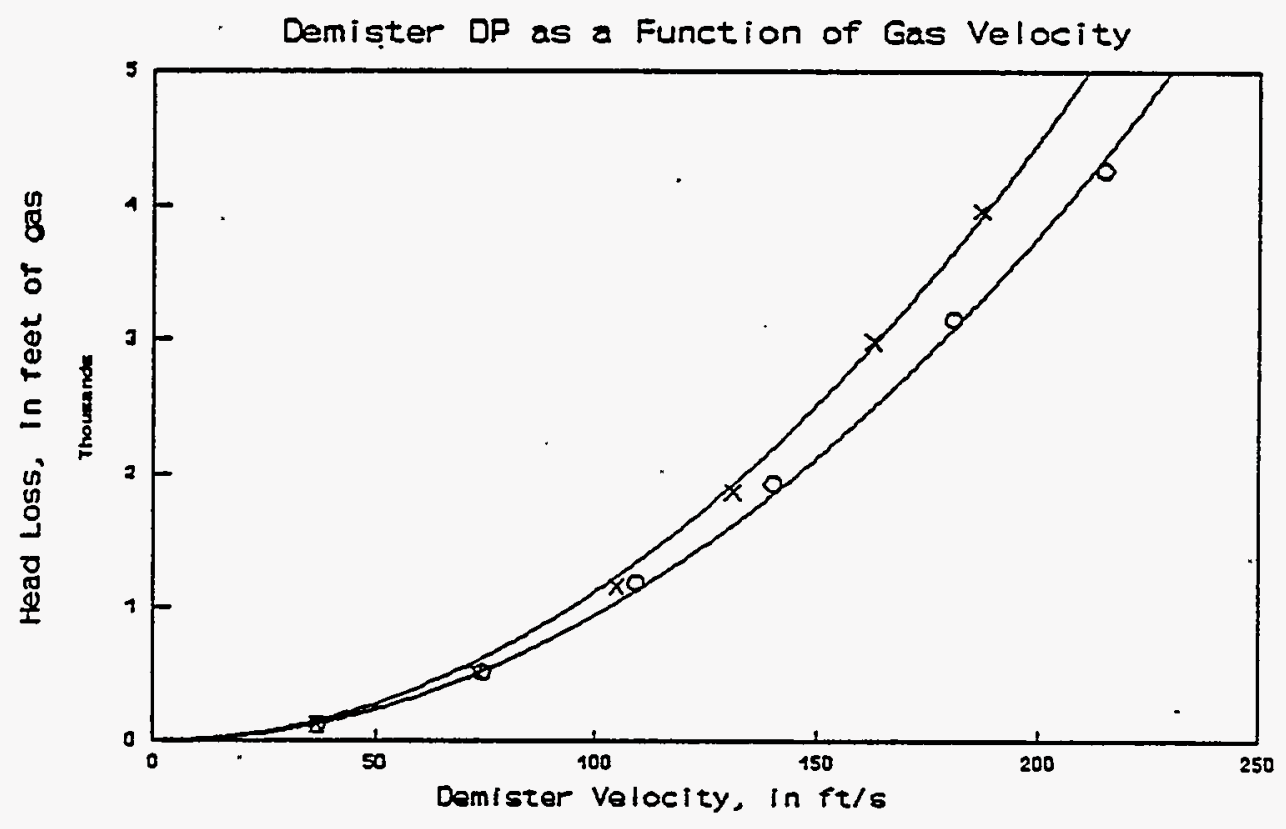

_Fit Eased on Exit Condition

x

0 Ooserved Eused on Exit Condition

oberved Beed on Avereos condition

LFir eseed on Exit Condition

Figure 2.3. Chevron Demister Headloss vs. Approach Velocity in 4-in. Schedule 40 pipe. Data fitted using the gas conditions at the exit and at the average of entrance and exit conditions. The standard deviations of the resistance coefficients were exit conditions= 1.218 , average conditions $1.11 \%$. 


\subsection{SBS Pressure Drop VS. Flow}

The available data on the SBS pressure drop is combined in Figure 2.4. The plot shows the pressure drop as a function of the gas superficial velocity in the bed. This velocity is calculated based on exit conditions and includes humidity. The effect of the pressure drop in the chevron demister is included. The various types of data points are indicated by different symbols:- The categories are divided into steam surge, intermediate steam values, normal steam values, air only values and air only values where SBS and demister pressure drop were measured separately ("SBS dp observed values"). Each data point represents an average of about 10 minutes of operation except in the case of steam surge cases. In steam surge cases the initial and end points were taken and plotted separately. In the case of separately measured SBS and demister pressure drops the two were added in order to compare the data on the same basis. In addition, when the offgas line was disconnected, an estimate of the pressure drop due to the entrance of the disconnected offgas line was subtracted from the measured pressure drop.

Figure 2.5 shows the pressure drop across the SBS (not including the chevron demister) as a function of flow. The data has been adjusted to remove the predicted frictional loss due to the chevron demister. In addition, points measured with the offgas line disconnected have been adjusted for the entrance loss at the top of the downcomer. By comparison to Figure 2.4, it can be seen that the chevron demister is the primary contributor to the increase in pressure drop with flow. With the effect of the demister removed the variation of the pressure drop with flow is relatively minor.

In addition, the steam flowrate has little impact on the pressure drop. The difference in the pressure drop between steam and non-steam runs is primarily due to the pressure drop in the downcomer and downcomer exit. The SBS observed points appear to be biased high. This is most likely due to the lower temperature and higher pressure in the SBS downcomer resulting in higher pressure drops for the same superficial bed velocity (offgas line is disconnected from top of SBS). 


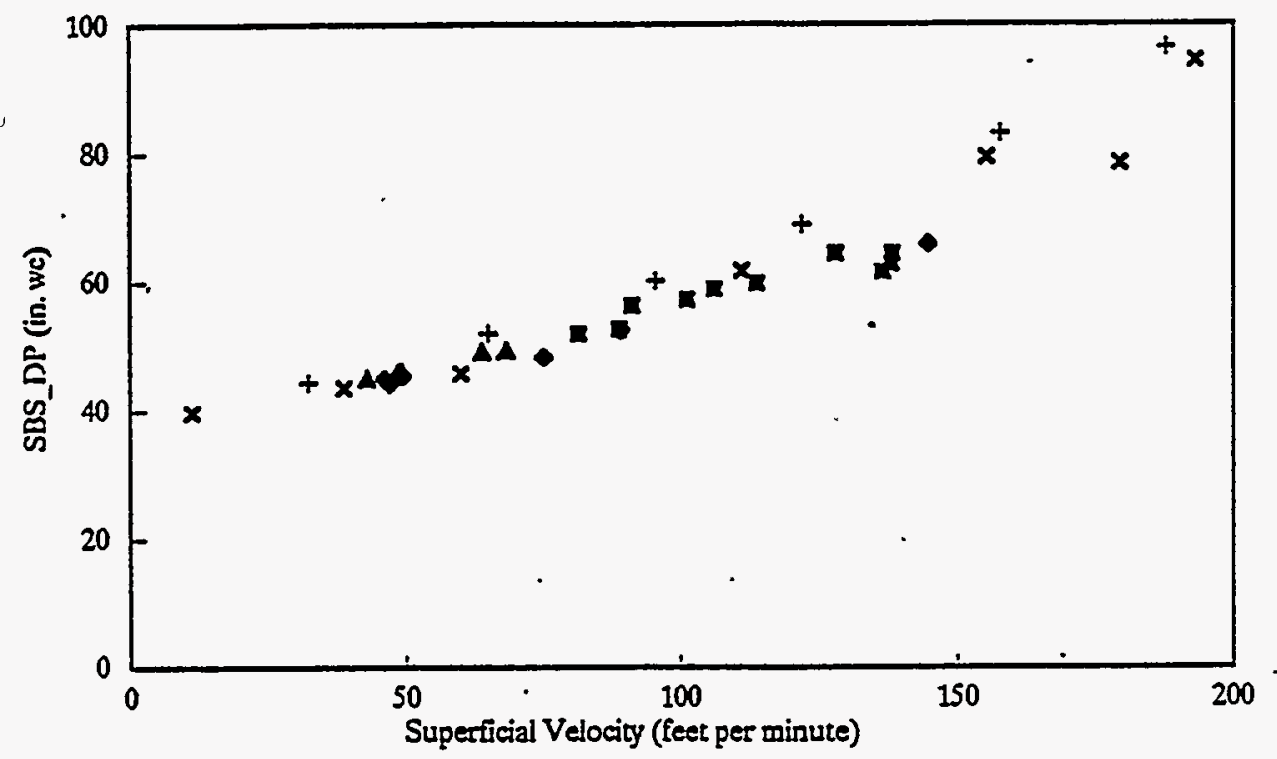

- Surge Conditions

- Normal Conditions

4 Intermediate Conditions

$x$ Air Onty Conditions

+ SBS dp observed values

Note: Where offgas line was disconrected, entrance loss has been subracted.

Where the SBS pressure drop did not include demister an estimate bas beed added.

Figure 2.4. SBS Pressure Drop vs Superficial Bed Velocity. Pressure drop includes downcomer, SBS bed, and chevron demister. Superficial bed velocity includes humidity in outlet. 


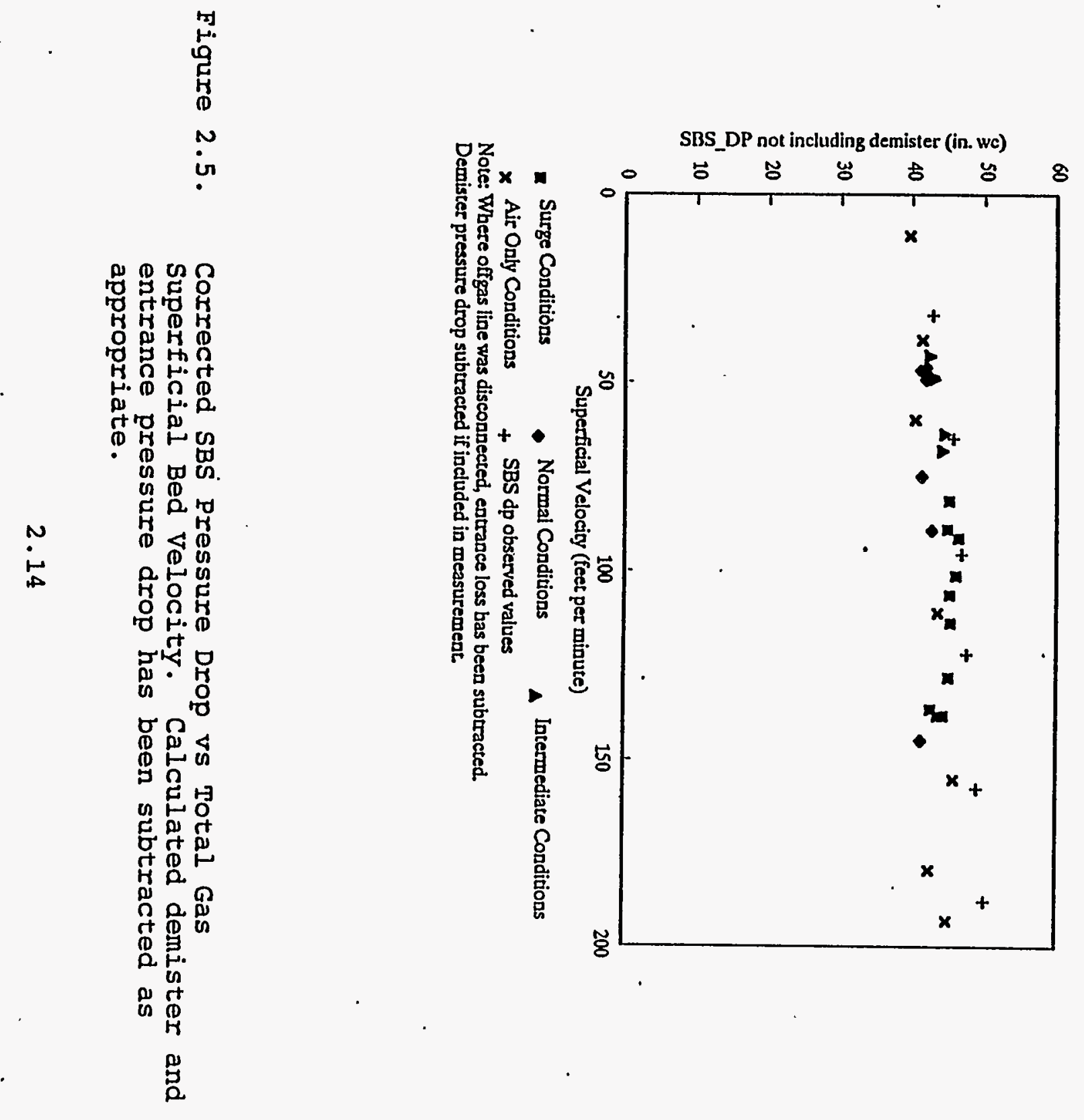


The most reliable pressure drop information is that for which the offgas line was disconnected and the pressure drop across the demister and SBS were measured separately. The data are shown in Figure 2.6. The measured pressure drop is corrected by subtracting estimates for the entrance, the frictional loss of the downcomer, and the loss due to the downcomer exit. The resulting pressure drop curve (for SBS bed and distribution plate) indicates a maximum in the pressure drop vs. flow curve (bottom curve).

A similar type of curve was developed for the Submerged Gravel Scrubber (SGS) ${ }^{6}$. The relationship obtained for the submerged gravel scrubber is shown in Figure 2.7 for comparison to the current results. The pressure drop increases about 0.6 $\mathrm{kPa}(2.4 " \mathrm{WC})$ as flow increases and reaches a maximum at about $0.5 \mathrm{~m} / \mathrm{s}$ (98 $\mathrm{ft} / \mathrm{min}$ ). After reaching a maximum, the pressure drops across the bed drops off rapidly. It is possible that the curve drops off more quickly in the sGS due to the void content of the packing $(\approx 0.45)$ being lower than in. the SBS $(\approx 0.75)$.

\section{Discussion of Potential SBS Pressure Drop Mechanisms}

As the gas flow increases from zero, the pressure drop. through the holes in the distribution plate and the frictional resistance to flow in the bed increases. The increase in pressure drop is counteracted to some degree by the decreasing static Iiquid head in the bed caused by the void volume in the bed. As the superficial velocity reaches about $80 \mathrm{ft} / \mathrm{min}$ the curve reaches a maximum pressure drop and then decreases. The maximum pressure drop is very near the 4 " length of the notches in the liquid riser tubes. It is possible that in this region some gas flow in these risers occurs.

At superficial bed velocities greater than $80 \mathrm{ft} / \mathrm{min}$, the pressure drop for the bed and plate actually decrease slightly with flow. The superficial velocity where this maximum occurs corresponds closely to the point where the SBS bed is relatively fully utilized. It is also the point where there is a break in the void volume vs. flow curve (see section 2.8).

-5 Measuring without the effect of the demister increases accuracy by eliminating the need for a correction which could potentially introduce error. However, with the offgas line disconnected the absolute pressures are higher which may slightly increase frictional losses in the SBS downcomer and downcomer exit.

B Owen, O. K., The Development of an Emergency Air Cleaning System For Iiquid Metal Reactors. HEDI 6859, Hanford Engineering Development Laboratory November 1980. 


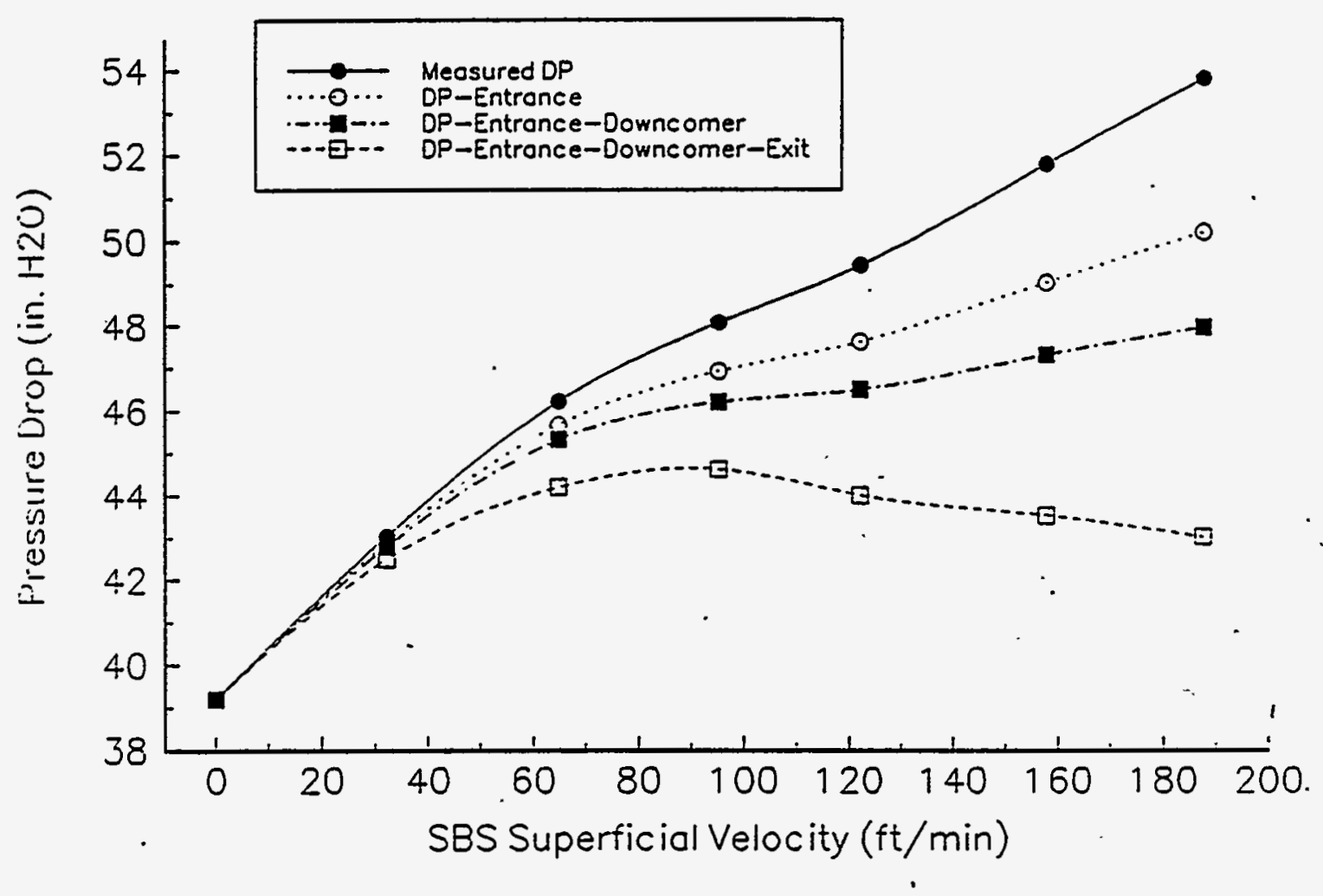

Figure 2.6 Measured SBS Pressure Drop vs Total Gas. Superficial Bed Velocity. Plot shows the pressure drop vs. flow relationship with cumulative corrections for entrance, downcomer, and downcomer exit loss. 


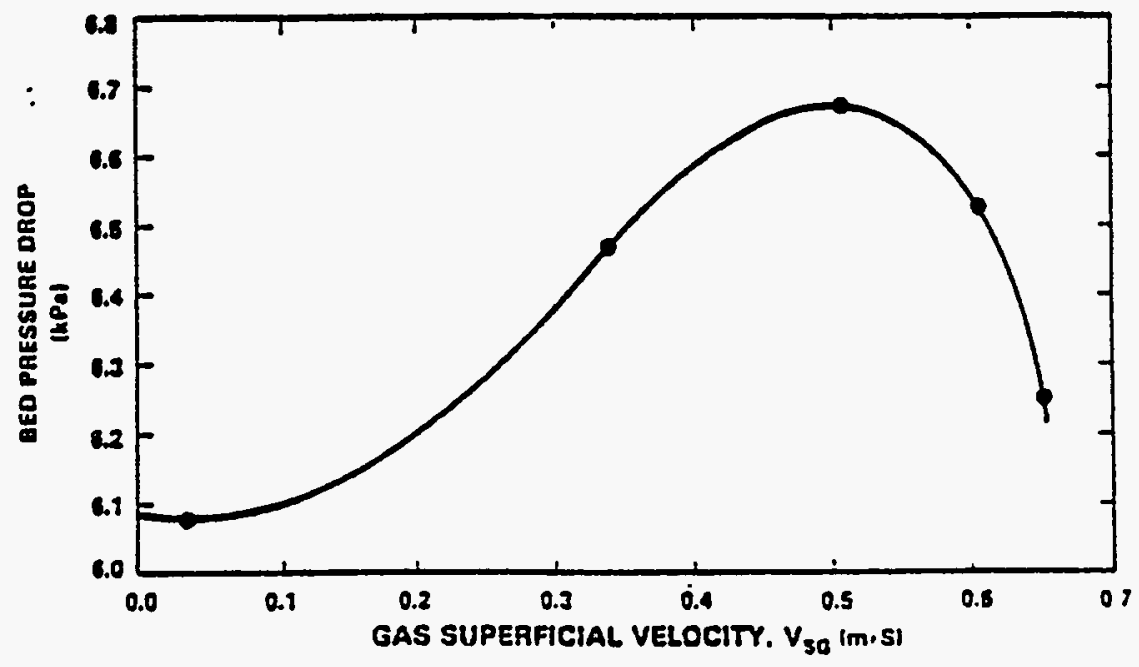

mot wese res

Figure 2.7. Pressure Drop Across Packed Bed for the Submerged Gravel Scrubber. Reproduced from: Owen, O. K., The Development of an Emergency Air Cleaning System For Iiquid Metal Reactors. HEDL 6859, Hanford Engineering Development Laboratory November 1980 . 


\subsection{SBS Bed Temperatures}

SBS bed temperatures were measured by 27 thermocouples within the SBS bed as described in section 2.1 above. This was done to determine if channeling of gas and steam was occurring and to determine the degree uniformity of temperatures throughout the bed in all directions. Figures 2.8 to 2.10 show the reported temperatures as averages from different groupings of thermocouples during the $51.2 \mathrm{sfpm}$ steam surge case. This case was chosen for illustration because the SBS temperature did not change significantly over time during testing. Two thermocouples were not providing accurate readings at the time of the testing and were excluded from the averages. However, most data points represent an average of 9 thermocouples.

No temperature variation between the three sectors of the SBS was observed, as shown in Figure 2.8. When the thermocouples were grouped according to vertical or radial position, only small differences were found. While the SBS was operating, the upper layer and outer ring of thermocouples reported temperatures about 0.5 degrees higher than other regions in the bed (Figures 2.9 2.10). Also, deviations of less than $2^{\circ} \mathrm{C}$ were observed between the averages of the upper, middle and lower layer of thermocouples while the SBS was not operating, as figure 2.11 depicts. When operation is started, the temperatures converge. The SBS would have been expected to be nearly isothermal prior to starting operation. The standard deviation of the average temperature in the three groupings was typically about $0.5^{\circ} \mathrm{C}$. Given the low precision of the data relative to the small differences observed, it can only be concluded that the sBS bed is very nearly isothermal during operation. If temperature. differences do exist within the bed they are less than $2^{\circ} \mathrm{C}$.

Temperatures were also logged at 5-second intervals in order to determine if fluctuations occurred which might indicate noncondensed steam within the packed bed. These temperatures are shown with upper, middle and lower bed thermocouples plotted together in Figures $2.12-2.14$. No evidence of non-condensed steam was noted in the data. 


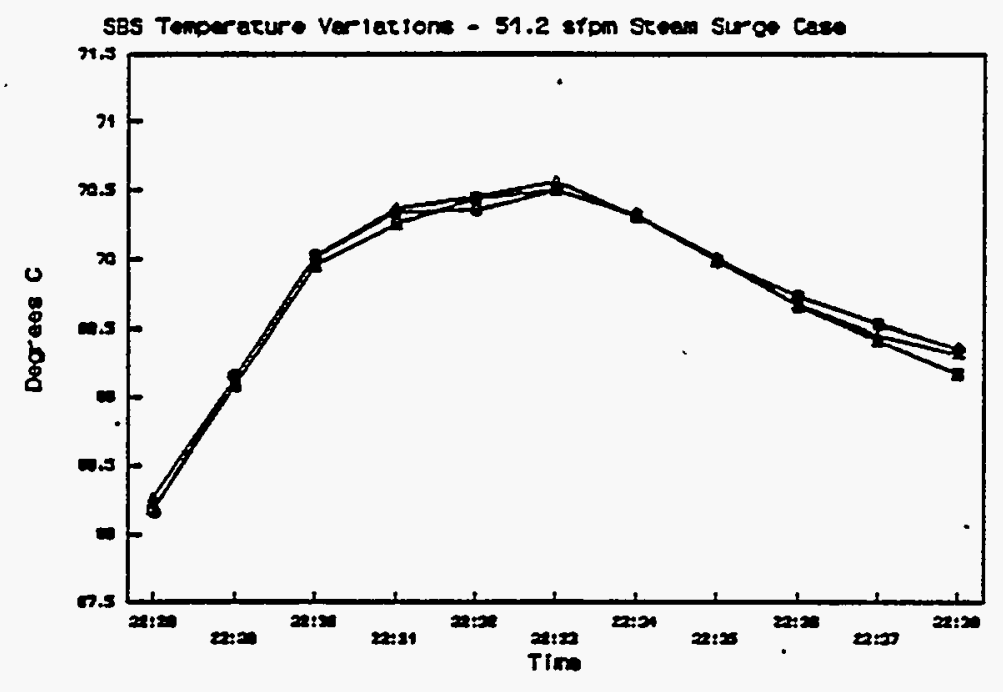

FIGURE 2.8. SBS temperature variations according to SBS sector.

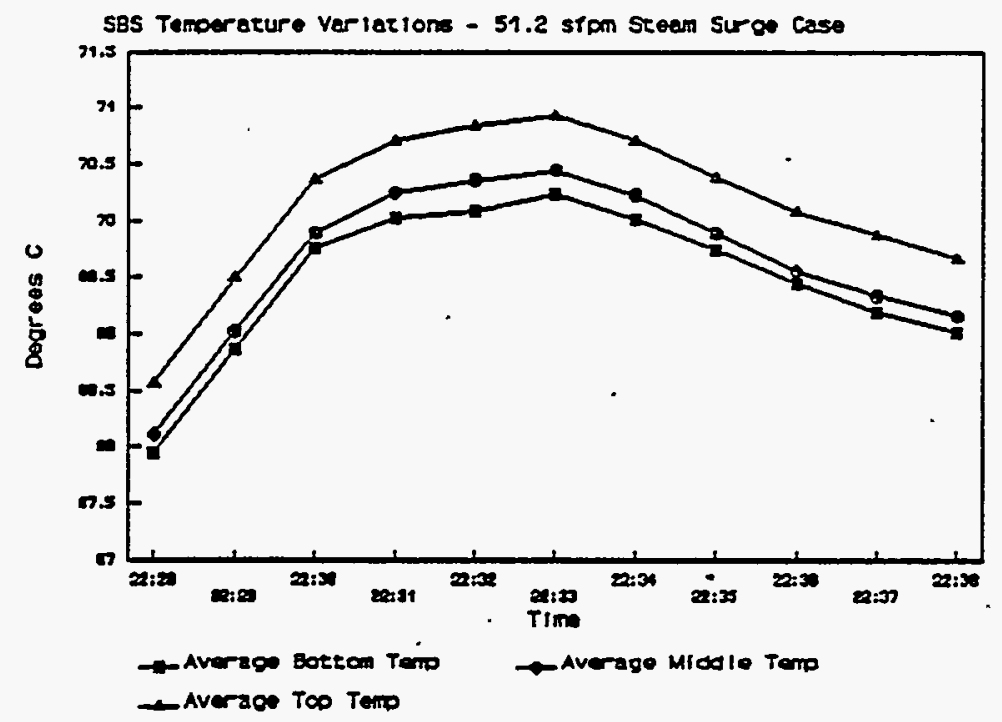

FIGURE 2.9. SBS temperature variations according to vertical position. 


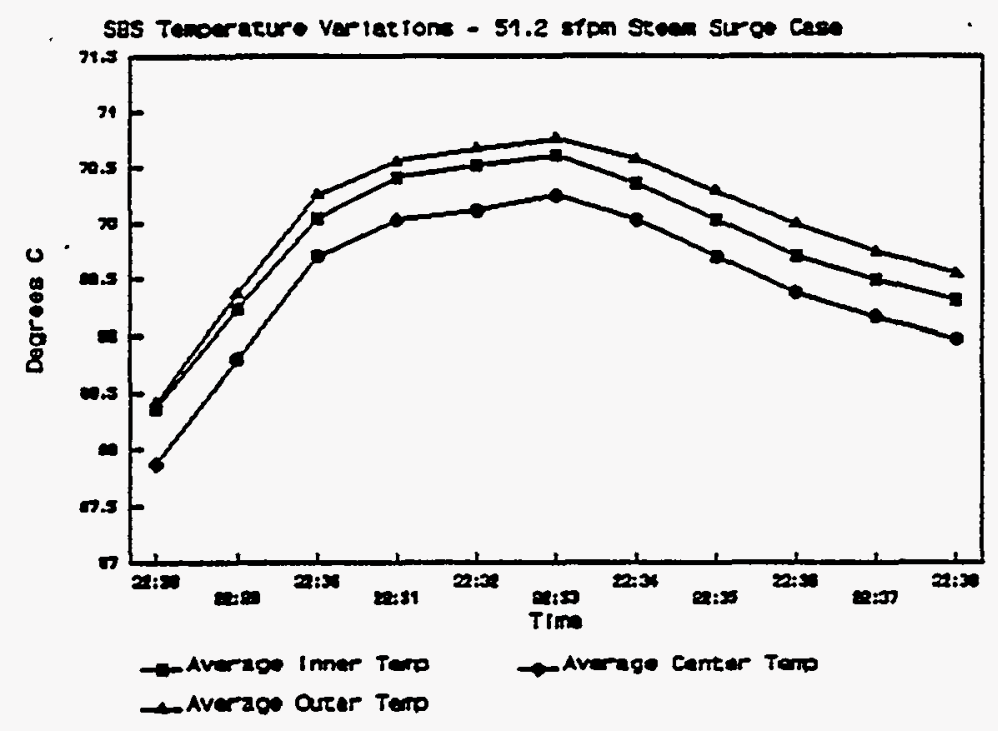

FIGURE 2.10. SBS temperature variations based on radial position.

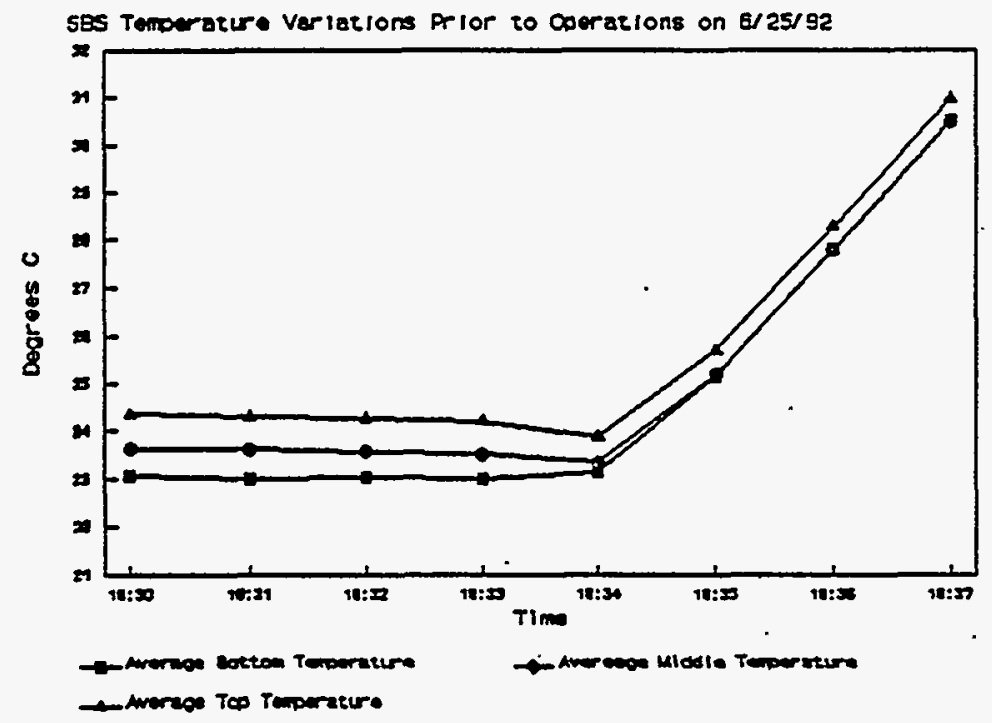

FIGURE 2.11. Reported vertical temperature differences in SBS while at startup. Steam Flow initiated at $18: 34$. 


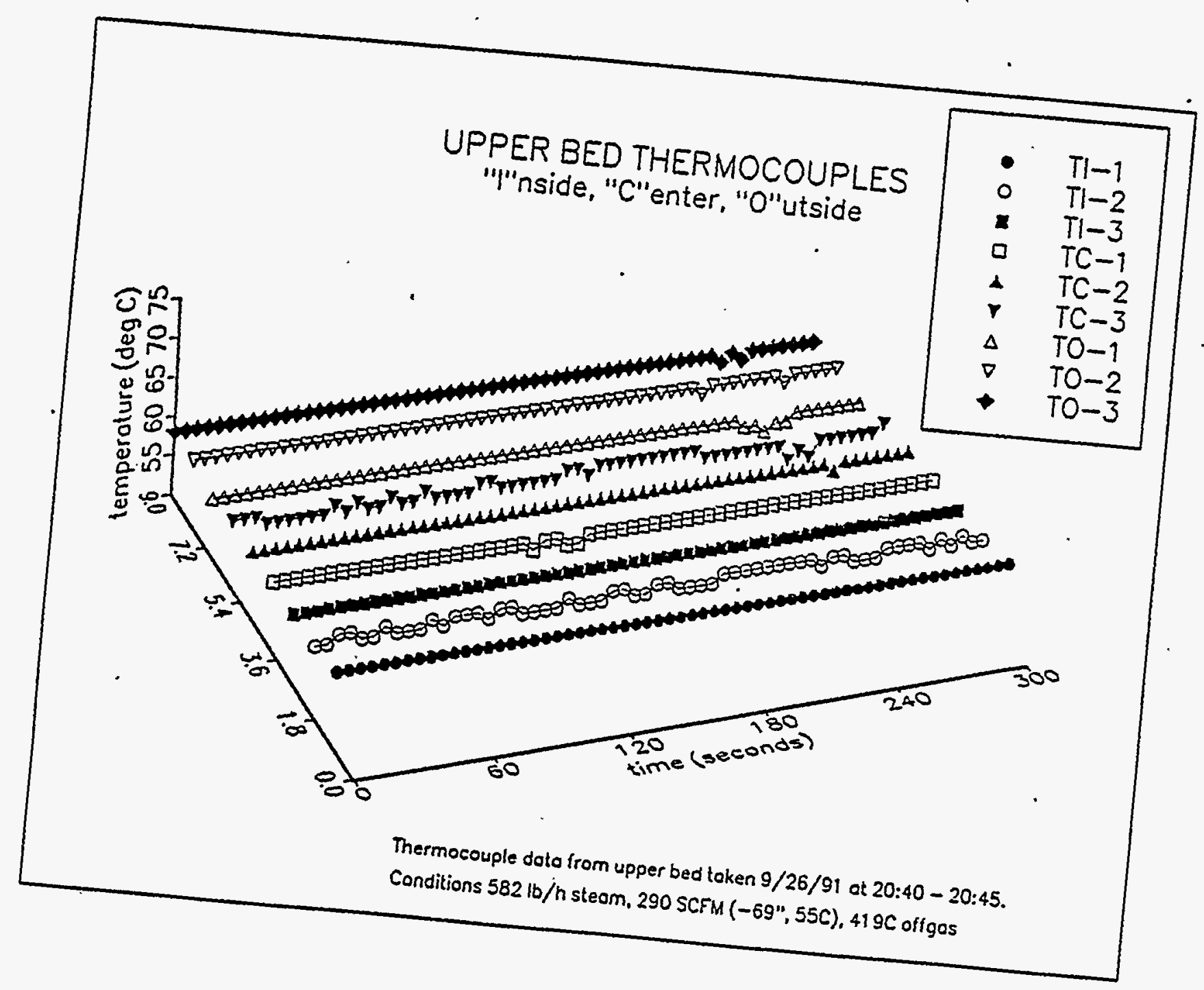

Figure 2.12

SBS temperatures

packed bed logged in the upper

at 5-second intervals.
inton

2.21 


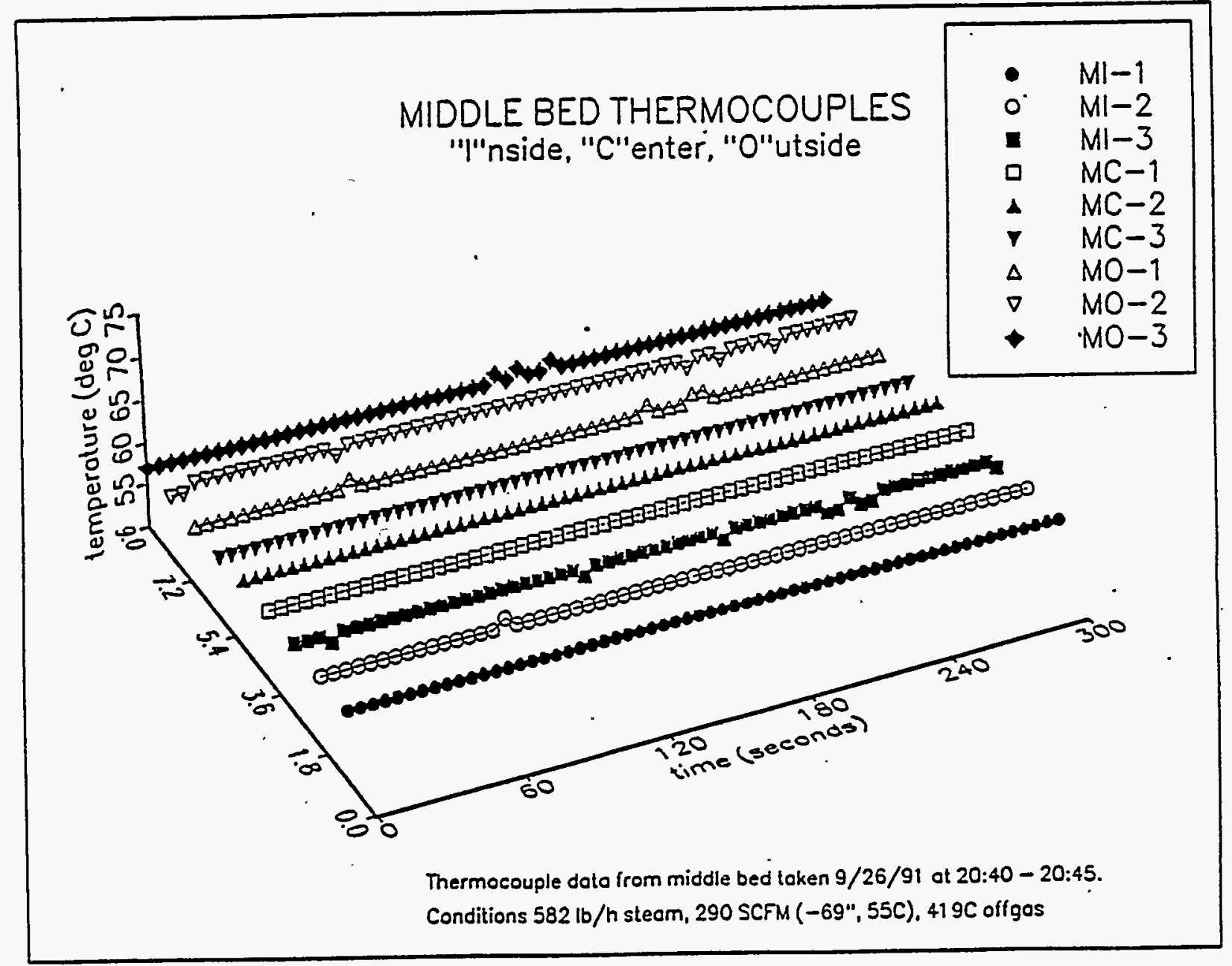

Figure 2.13 SBS temperatures in the middle region of packed bed logged at 5-second intervals: 


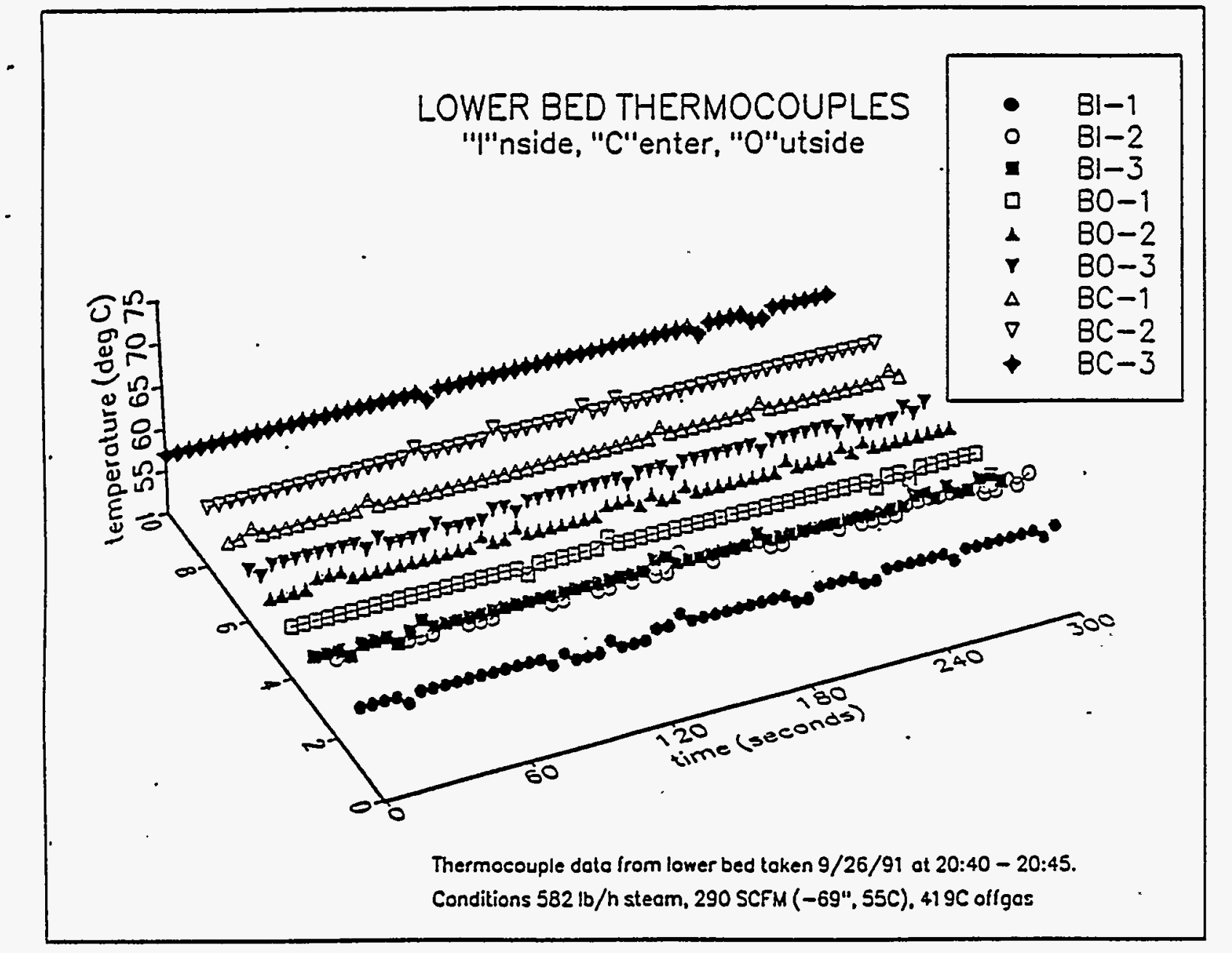

Figure 2.14 SBS temperatures in the lower region of packed bed Iogged at 5-second intervals. 


\subsection{Heat Balances}

Heat balances were performed for the data points reported in tabular form in section 2.2. Heat balances are only performed for cases involving steam injection. The heat balances were performed as a consistency check of the data. The enthalpy change of the steam and air entering the SBS due to temperature changes and steam condensation is considered the heat input to the system. The heat out of the system consists of the heat removed via the cooling coils, an estimate of convective cooling of the vessel exterior and an accumulation term accounting for any temperature change in the SBS. . The steam injection is considered the only source of steam (humidity in air inleakage is neglected). The SBS heat capacity is assumed to be that of 2768 liters of water which is the volume of a 60-in. diameter, 59.75in. high container of water. No adjustments are made for the heat capacity of SBS steel, packing material, or change in water quantity due to displacement by air at higher flowrates. These assumptions limit the accuracy of the heat balance but the heat balance is still a useful, consistency check of the data. The data is summarized in Table 2.2. A positive sign indicates more heat calculated as input than calculated as removed. The error is calculated as $100 \%$ (inlet-outlet) $/($ (inlet+outlet) $/ 2$ )..

Table 2.2 Heat Balance Summary

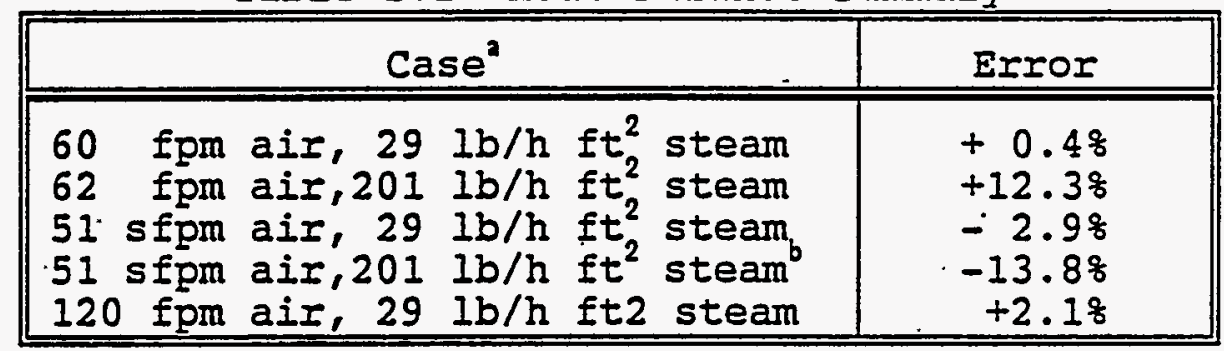

a Case indicates the target flow rates. For actual flow rates, see section 2.2 .

b The data for the first $.51 \mathrm{sfpm}, 201 \mathrm{lb} / \mathrm{h} \mathrm{ft}^{2}$ case is not shown due to some uncertainty about exactly when the cooling water flow was increased during the data collection period.

There appears to be a systematic trend for steam surge cases having larger errors than non-surge cases. The same was true, to a lesser extent for the cases examined in data need 3.1. There are three known potential causes for this trend.

The most likely reason for this trend is an inaccuracy in the cooling water flow rate. The flowmeter calibration was performed up to $23 \mathrm{gpm}$. The flowmeter is not very accurate but is very linear up to $23 \mathrm{gpm}$. During steam surge cases flows as high as $33 \mathrm{gpm}$ were used in an attempt to control the SBS 
temperature. It is possible that at the high flowrates used to control the SBS temperature the flow relationship for the meter is no longer linear.

other potential causes for the larger error in steam surge cases would be due to an inaccuracy in the steam meter (although the steam surge is within the calibrated range for the steam meter), or possibly an error estimating the quantity of water vapor exiting the SBS. This error is more significant for steam surge cases because the variation of water vapor pressure with temperature is much more rapid at the higher temperatures experienced during a sustained surge condition. This could result in errors in the exit humidity calculation. The error being due to the steam meter or humidity estimate is somewhat discounted due to a lack of a similar trend in flow comparisons discussed in section 2.7 . 


\subsection{Offgas Flow Comparisons}

As a check on the consistency of the data the flowrates of air only (excluding steam and non-condensed moisture behind the SBS) were compared. The gas stream is assumed to be saturated leaving the SBS and humidity in air inleakage to the melter is ignored. The comparison is shown in Figure 2.15. There seems to be a trend within the 3.1 data for downstream flows to be slightly higher. However, this trend does not appear to carryover into the 3.2 data set. Overall, the flowrates indicate good agreement. 


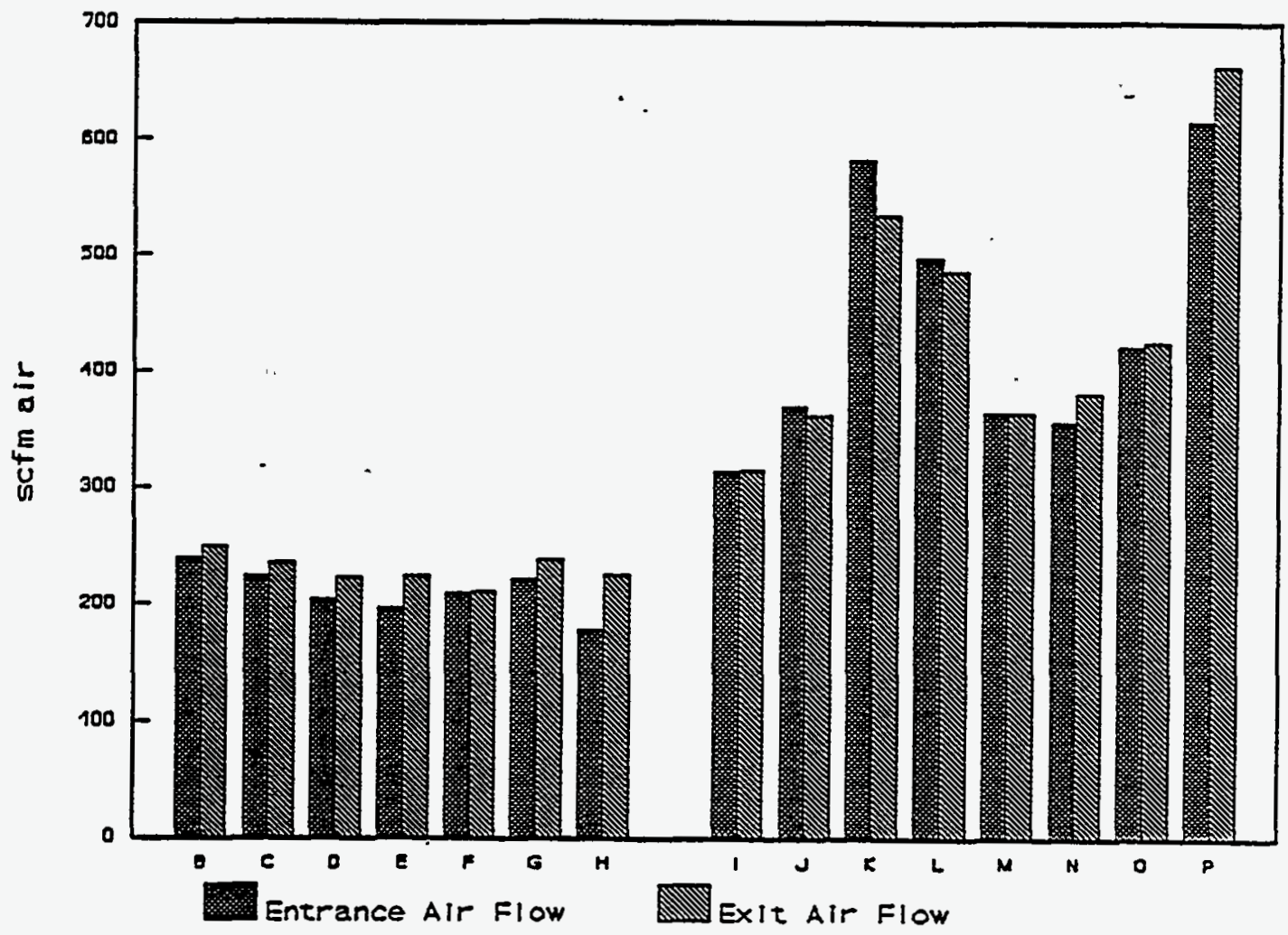

Technical Need 3.1:
A. Normal Case
B. Maximum Plenum Temperature
C. $28 \mathrm{lb} / \mathrm{h}-\mathrm{ft}^{2}$ Steam Flow
D. $55 \mathrm{lb} / \mathrm{h}-\mathrm{ft}^{2}$ Steam Flow
E. $86 \mathrm{lb} / \mathrm{h}-\mathrm{ft}^{2}$ Steam Flow
F. $118 \mathrm{lb} / \mathrm{h}-\mathrm{ft}^{2}$ Steam Flow
G. $132 \mathrm{lb} / \mathrm{h}-\mathrm{ft}^{2}$ Steam Flow
H. $189 \mathrm{Ib} / \mathrm{h}-\mathrm{ft}^{2}$ Steam Flow

Technical Need 3.2:
I. $60 \mathrm{fpm}, 29 \mathrm{lb} / \mathrm{h}-\mathrm{ft} \mathrm{t}^{2}$.
J. $60 \mathrm{fpm}, 201 \mathrm{Ib} / \mathrm{h}-\mathrm{ft}^{2}$
R. $120 \mathrm{fpm}, 29 \mathrm{lb} / \mathrm{h}-\mathrm{ft} t^{2}$
I. $120 \mathrm{fpm}, 201 \mathrm{lb} / \mathrm{h}-\mathrm{ft}^{2}$
M. $51.2 \mathrm{sfpm}, 29 \mathrm{lb} / \mathrm{h}-\mathrm{ft} t^{2}$
N. 51.2 sfpm, $201 \mathrm{lb} / \mathrm{h}-\mathrm{ft}_{2}^{2}$
0 . $51.2 \mathrm{sfpm}, 201 \mathrm{lb} / \mathrm{h}-\mathrm{ft}^{2}$ (repeat)
P. Air Flow Only

Figure 2.15. Comparison of Air-Only Flow Measurements Before and After the SBS. 


\subsection{Estimate of Void Fraction In Bed}

An attempt to measure the void fraction of the SBS bed was made by measuring the quantity of overflow from the SBS at various air flow rates. A number of assumptions were made to allow this calculation. First, the design equation for the pressure drop through the holes of the SBS plate was used to estimate the bubble thickness below the distribution plate. The bubble was assumed to be uniform thickness. For the liquid above the bed it was assumed that the ratio of water to air was the same as that in the bed. Based on the atmospheric pressure and relative humidity (exterior, no measurement made in building) for the day of the test a correction for the water evaporated during the test was made. The volume of the downcomer which is filled with water prior to starting the air is taken into account in the calculation. No correction is attempted for local swelling of the liquid surface over the bed.

For comparison, the preliminary data taken over a smaller range prior to installation of the temporary blower was evaluated in the same manner. The previous data was collected with the drain at the lower level rather than the upper level. The two data sets are shown in Figure 2.16. As can be seen, the agreement is fairly good. The cluster of points located at 55 fpm are due to extended operation at a single velocity. The SBS level continued to slowly drain as the testing proceeded, resulting in the group of points for the same velocity. The superficial velocity shown in the figure is the total air and water vapor flow evaluated at exit conditions.

The curve appears to reach be Iinear up to approximately 60 $\mathrm{ft} / \mathrm{min}$. At approximately 60-80 ft/min the curve bends over. This flow rate approximately corresponds to the region where the bed becomes nearly completely utilized (section 2.10) and the pressure drop for the packed bed passes through a maximum (section 2.4). 


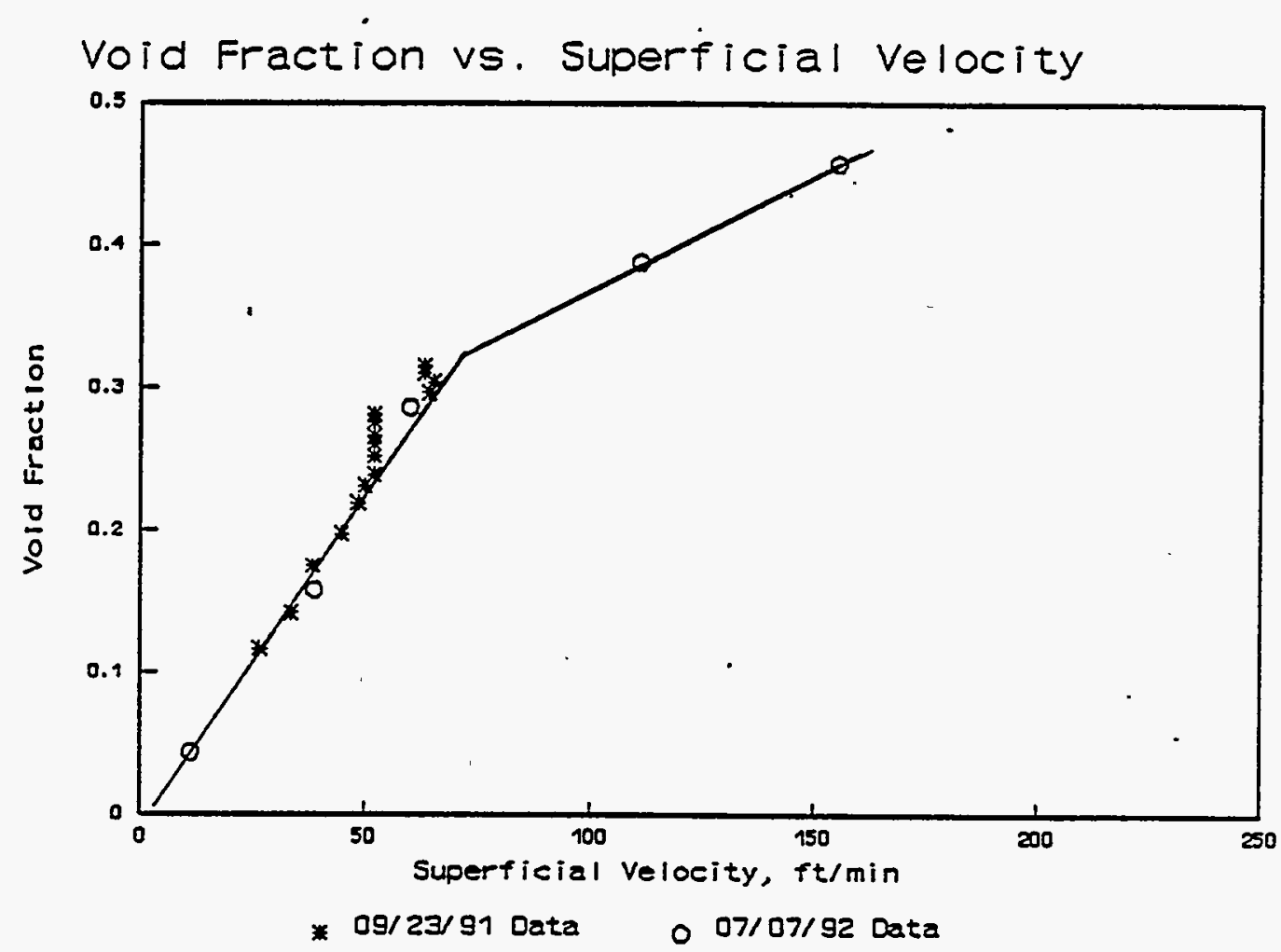

Figure 2.16. Estimated Void Fraction in SBS Bed vs. Superficial Total Gas Flow. Total void fraction available within packing is 0.75 . 


\subsection{Circulation Velocities}

The circulation velocities within the SBS are estimated using RTD elements positioned above and below the cooling coils. The amount of heat removed through the coils is used along with the temperature change of the scrub solution to estimate the rate at which the scrub solution is passing over the cooling coils. The superficial circulation rates are shown in Table 2.3 for the annular space and for the SBS bed. The flows shown do not account for the volume occupied by the bed packing, air voids, or the cooling coil tubes. Therefore, actual velocities of the liquid are higher. The sensitivity of the RTDs to detect temperature differences was $0.25^{\circ} \mathrm{C}$. Observed temperature differences used to calculate circulation velocities were 0.7 to $0.8^{\circ} \mathrm{C}$ under normal conditions and 1.2 to $1.6^{\circ} \mathrm{C}$ under surge conditions. Data for the surge cases is considered more accurate due to the higher temperature difference in the annulus. The average of superficial bed velocities obtained under steam surge conditions is $10.5 \mathrm{ft} / \mathrm{min}$.

Table 2.3 Iiquid Circulation Velocities

\begin{tabular}{|c|c|c|}
\hline Case $^{2}$ & $\begin{array}{c}\text { Annular } \\
\text { Superficial } \\
\text { Velocity (ft/min) }\end{array}$ & $\begin{array}{c}\text { Bed Superficial } \\
\text { Velocity } \\
\text { (ft/min) }\end{array}$ \\
\hline 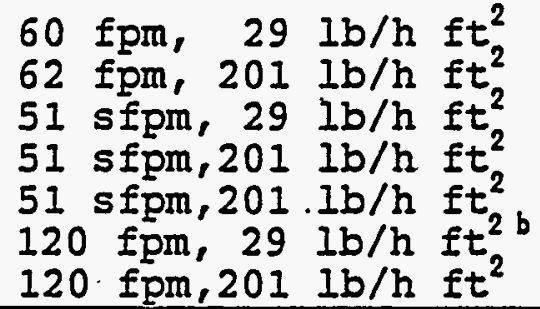 & $\begin{array}{l}4.0 \\
5.4 \\
3.7 \\
7.9 \\
4.3 \\
3.4 \\
5.9\end{array}$ & $\begin{array}{l}7.3 \\
9.2 \\
6.7 \\
14.3 \\
7.8 \\
6.2 \\
10.7\end{array}$ \\
\hline
\end{tabular}

Target flows given to identify case. For actual flow rates, see section 2.2 .

Recorded values indicated a temperature increase as the liquid flowed over the coolant coils on one side of the SBS. It is believed that the data was recorded in the wrong blanks on the data sheet. The value shown is calculated after switching the two points. 
Owen ${ }^{7}$ determined maximum liquid superficial velocities of approximately $2.7 \mathrm{ft} / \mathrm{min}$. Similar results were obtained for a perforated plate and a screen. The liquid velocities obtained with the IFCM distribution plate are 2 to 4 times greater. The combination of the distribution plate and the saddle packing is believed to be the reason for the improved liquid circulation.

An estimate an the upper-bound circulation velocity can be made by using the estimate of void fraction in the SBS bed (developed above in section 2.6) and the air flowrate to calculate the actual velocity of the air moving through the SBS bed. The air moves through the bed more rapidly than the liquid. However, if it is assumed that the liquid and air move at the same velocity, an upper bound estimate can be calculated for the liquid circulation velocity. This is done by assuming a uniform distribution of the air flow across the distribution plate (actually flow is more concentrated near the downcomer, especially at lower flows). Figure 2.17 shows the estimates of the air bubble velocities within the sBS bed.

Figure 2.18 shows the data platted in terms of the superficial flow of liquid through the $6.8 \mathrm{ft}^{2}$ area of the bed. The fact that the upper bound indicates flows nearly a factor of 10 greater than that measured by the RTD indicates that the gas is travelling through the bed substantially faster than the liquid.

${ }^{7}$ Owen, O. K., The Development of an Emergency Air Cleaning System For Iiquid Metal Reactors. HEDL 6859, Hanford Engineering Development Laboratory November 1980. 
Bubble Velocity vs. Superficial Velocity

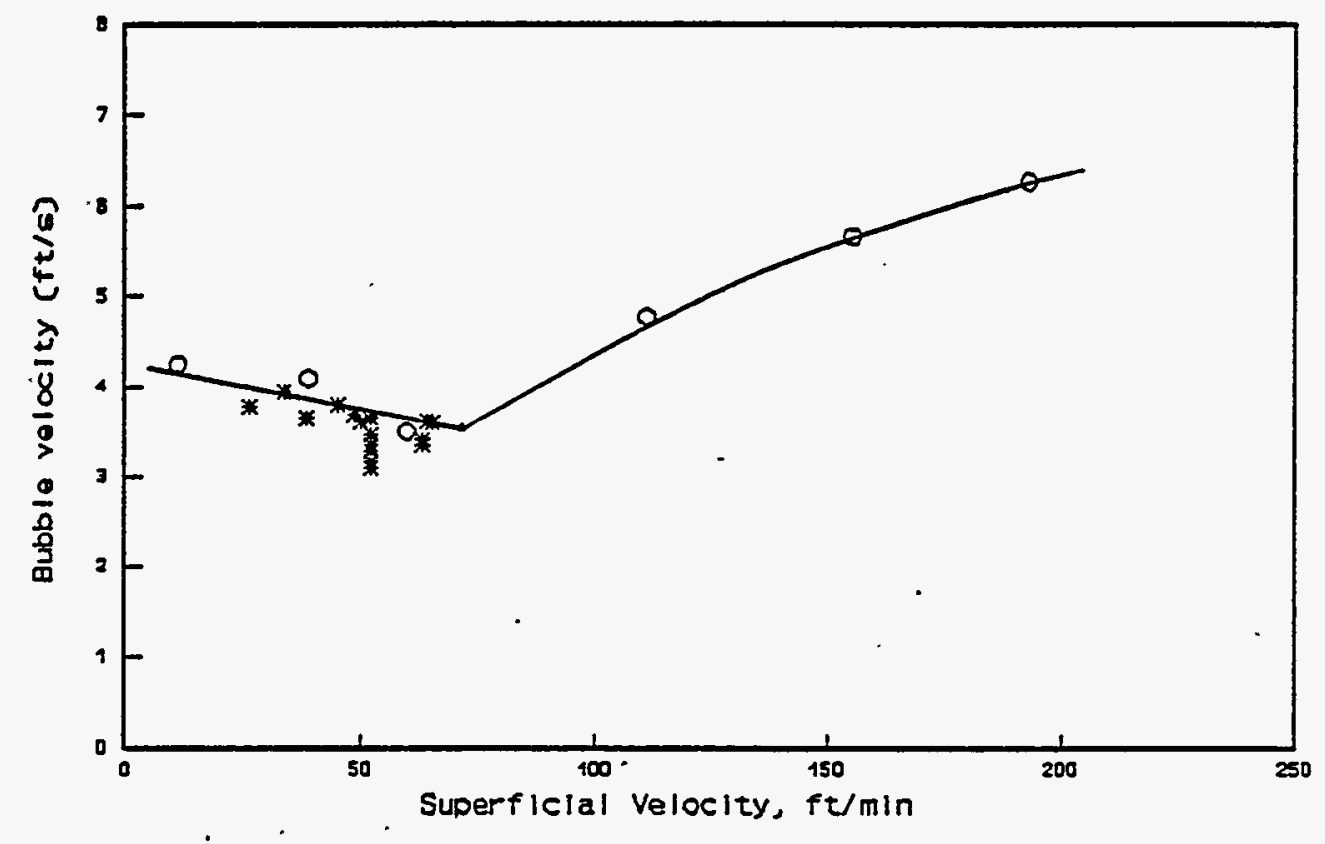

* 09/23/91 Data o 07/07/92 Data

Figure 2.17. Estimated Actual Velocity of Gas. in SBS Bed. 


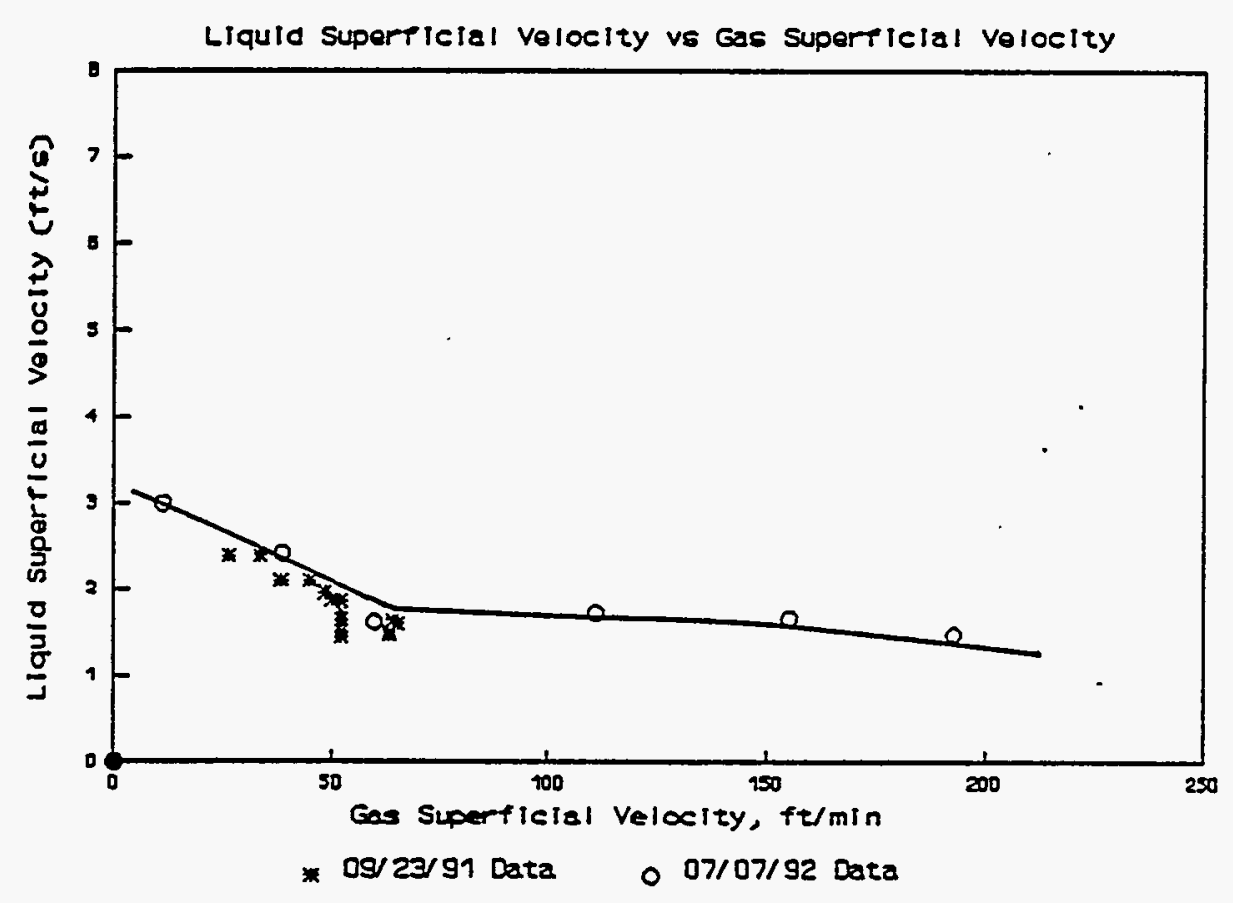

Figure 2.18. Estimated Superficial Iiquid Velocity vs Superficial Air Velocity in SBS Bed 


\subsection{SBS Bed Utilization}

The depth and the radius of the gas bubble beneath the distribution plate can be estimated from SBS pressure drop data and from visual observation of the gas bubbling through the SBS bed. For the purposes of assessing the bubble depth, the SBS bed-only pressure drop is assumed to result exclusively from the submergence of the downcomer exit and from the depth of the bubble. The pressure drop due to submergence is assumed to be $39: 2$ in. WC and unchanging with increasing void fraction. The additional pressure drop due to the bubble should have a maximum of 4 to 5 in. WC as it reaches the distribution plate bypass tubes extending from the plate. As shown in the lower curve in Figure 2.6, the SBS bed pressure drop vs. superficial velocity curve increases from 39.2 in. WC and reaches a maximum of 44.6 inches. There is uncertainty in the corrections applied to get the depth of the bubble but it is likely that gas is entering the liquid risers in the area of the pressure drop maximum.

The observed radius of SBS bed usage is shown in Table 2.4 . These measurements indicate that the flow is non-uniformly distributed across the bed at superficial velocities less than or equal to $37 \mathrm{fpm}$. It cannot be concluded that the bubble is or is not uniform across the distribution plate. Because of the maximum in the pressure drop flow curve, a uniform bubble does not necessarily imply uniform flow distribution. Two points with the same bubble depth can have widely different flows. The visual data indicate that the bed becomes fully utilized between 37 and $111 \mathrm{ft} / \mathrm{min}$. Other data has shown changes in the dependency on flow at a velocity of 60-80 ft/min . It is possible that the bed becoming fully utilized is responsible for the changes in operation observed in this region.

Table 2.4 SBS Bed Utilization

\begin{tabular}{||l|c|c|c|}
\hline $\begin{array}{l}\text { Superficial Velocity } \\
(\mathrm{ft} / \mathrm{min})\end{array}$ & 11 & 37 & 111 \\
\hline Radius of Bed Usage ( $\left.{ }^{2}\right)$ & $7^{\prime \prime}$ & $11^{\prime \prime}-13^{\prime \prime}$ & $15^{\prime \prime}-17^{\prime \prime}$ \\
\hline
\end{tabular}

- Measured from downcomer centerline, based on visual observation of gas emerging from the top of the SBS bed. Radius is measured to the location where height of bubbles reduces to $1 / 2$ of the maximum height. Bed is considered fully utilized at 111 fipm.

8 when plotted against flow, the void content curve bends over in this region, the bed pressure drop curve passes through a maximum, and the estimated actual velocity of bubbles begin to increase. 


\subsection{Cooling Coil Heat Transfer Coefficients}

The cooling coil heat transfer coefficients were-calculated for the cases in which steam was used. The calculated coefficients are shown in Table 2.5. The coils have only been exposed to process water and should be free from fouling. The values are slightly less than but in reasonable agreement with the initially measured value of $208 \mathrm{BTU} / \mathrm{ft}^{2} \mathrm{~h}{ }^{\circ} \mathrm{F}$ reported in December 1991. The heat transfer coefficients were calculated as:

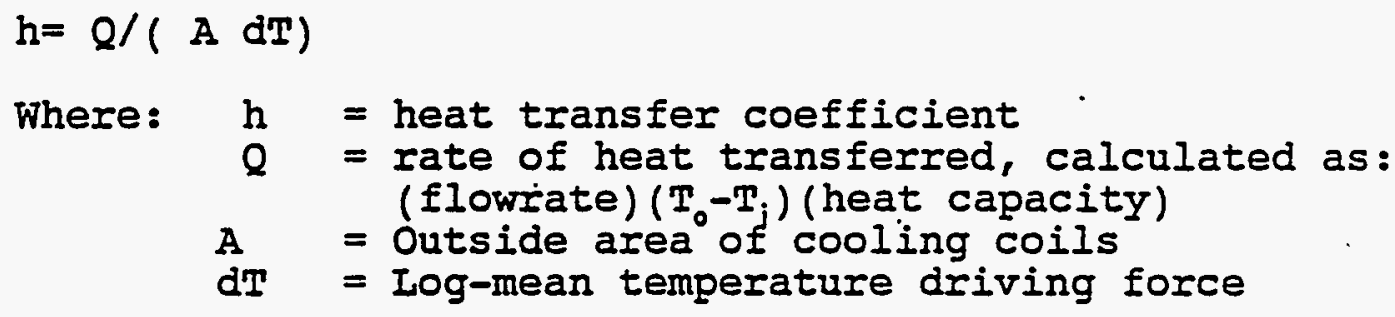

Table 2.5 Cooling Coil Heat Transfer Coefficients

\begin{tabular}{||c|c||}
\hline Case $^{2}$ & $\begin{array}{c}\text { Heat Transfer } \\
\text { Coefficient } \\
\left.\text { (BTU/h ft }{ }^{2} \mathrm{~F}\right)\end{array}$ \\
\hline $60 \mathrm{fpm}, 29 \mathrm{lb} / \mathrm{h} \mathrm{ft}^{2}$ & 109 \\
$62 \mathrm{fpm}, 201 \mathrm{lb} / \mathrm{h} \mathrm{ft^{2 }}$ & 181 \\
$51 \mathrm{sfpm}, 29 \mathrm{lb} / \mathrm{h} \mathrm{ft^{2 }}$ & 139 \\
$51 \mathrm{spm}, 201 \mathrm{lb} / \mathrm{h} \mathrm{ft^{2 }}$ & 178 \\
$120 \mathrm{fpm}, 29 \mathrm{lb} / \mathrm{h} \mathrm{ft^{2 }}$ & $171^{\mathrm{c}}$ \\
$120 \mathrm{fpm}, 29 \mathrm{lb} / \mathrm{h} \mathrm{ft^{2 }}$ \\
\hline
\end{tabular}

Target flow rates are used to identify case. For actual flow rates, see section 2.2 .

Only the repeated point is shown. During initial.test the cooling water rate was changed during the test period to control SBS temperature.

- Recorded values indicated a temperature increase as the liquid flowed over the cooling tubes on one side of the SBS. It is believed that the data was written into the wrong blanks on the data sheet. The value is calculated after switching the two points. 


\subsection{Pressure Oscillations In Offgas System}

During operation of the SBS, oscillations in pressure were observed. These oscillations were observed in the SBS as well as in the off-gas line pressure drop, the film cooler pressure drop, and the plenum pressure.

The oscillations occurred at stable frequencies ranging from approximately 0.7 to $3.5 \mathrm{~Hz}$. During four experiments in which the off-gas line was connected to the SBS, the frequency of the oscillations was approximately $3 \mathrm{~Hz}$. During later experiments in which the off-gas line was disconnected from the inlet to the SBS, the frequency was approximately 0.8 to $0.9 \mathrm{~Hz}$. The magnitude of pressure oscillations in the melter plenum was measured for these cases, while the SBS DP oscillations were measured for the later cases. The data is shown in Table 2.6.

Table 2.6 Offgas System Oscillations

\begin{tabular}{||c|c|c|c||}
\hline $\begin{array}{c}\text { Total Flow } \\
\text { (acfm) }\end{array}$ & $\begin{array}{c}\text { Frequency } \\
\text { (Hz) }\end{array}$ & $\begin{array}{c}\text { Osc. Magnitude } \\
\text { Plenum (in. WC) }\end{array}$ & $\begin{array}{c}\text { Osc. Magnitude } \\
\text { SBS DP (in. WC) }\end{array}$ \\
\hline \hline 748 & 2.75 & 2.8 & - \\
656 & 3.1 & 3.2 & - \\
983 & 3.0 & 4.0 & - \\
947 & 2.7 & 1.6 & - \\
1312 & $0.8^{\mathrm{d}}$ & - & 1.6 \\
263 & $0.9^{\mathrm{d}}$ & - & - \\
\hline
\end{tabular}

Based on SBS exit conditions.

Measured as difference of minimum and maximum pressure drop observed on a strip chart recorder.

- no data available.

Off-gas line disconnected.

The magnitude of oscillations in melter plenum pressure ranged from 1.6 to 4.0 in. WC for the conditions studied. However, the magnitude did not appear related to total flow.

The change in frequency between the cases where the off-gas Iine was connected or disconnected do not appear to be related to flow rate, since both a high flow and a low flow exhibited lower oscillation frequencies. This phenomena also does not appear to be related to the SBS exit pressure since it is roughly the same 
for both conditions.. Previous work by Hilliard et al. 9 with the submerged gravel scrubber found a weak correlation of the oscillation frequency to the gas flow rate. In that work the frequency varied from .39 to $0.53 \mathrm{~Hz}$ over a superficial velocity range of 20 to 140 . ft/min.

If the steady state average curve shown for the plate and packing in Figure 2.6 is taken as representative of the local pressure drop relationship for the SBS bed, it may provide an explanation for the pressure oscillations seen in the SBS. If the SBS operates to the right of the maximum of the curve, the flow will increase until the flow capacity is depleted due to the negative slope of the curve. When the capacity is depleted, the flow will decrease and the flow will build up against an increasing pressure drop curve until it again reaches the maximum and repeats the cycle again. This type of mechanism would explain why the frequency is lower when offgas line is disconnected. It takes longer to deplete the flow capacity when the flow to the SBS is not restricted by the offgas line. The testing performed by Hilliard et al. observed lower frequencies. It is believed that the reason for this is that downcomer in that work was larger relative to the bed area than the IFCM SBS downcomer.

Although the mechanism described for the pressure oscillations would require that the flow to reach the region of the maximum in the pressure drop vs flow curve, the local flow near the center of the downcomer may be in this region even at low flows due to the concentration of flow around the downcomer at low flows. If this proposed mechanism holds, it is a general property of submerged, packed beds and is not caused by the particular packing or distribution plate. This is strengthened by the fact that the oscillations were observed in the submerged gravel scrubber which had a different packing and distribution plate.

9 Hilliard, R. K., J.D. MCCormack, A.R. Postma, November 1981. SUBMERGED GRAVEL SCRUBBER DEMONSTRATION AS A PASSIVE AIR CLEANER FOR CONTAINMENT VENTING AND PURGING WITH SODIUM AEROSOLS -- CSTF TESTS AC7-AC10. HEDI-TME 81-30. Hanford Engineering Development Iraboratory. 
APPENDIX A: SPECIFIC CASE DATA FOR NEED 3.2

Tables

A. 160 fpm Normal Case Summary . A.3

A.2 62 fpm Steam Surge Case Summary $\quad \cdot \quad$ A.7

A.3 51.2 sfpm Normal Case Summary _. A.11

A.4 51.2 sfpm Steam Surge Case Summary $\quad$ A. 15

A.5 51.2 sfpm Steam Surge Case (repeat) Summary A.19

A. 6120 fpm Normal Case Summary $\quad$ A.23

A.7 120 fpm Steam Surge Case Summary $\quad$ A.27

A.8 180 fpm Air Only Case Summary $\quad$ A.31

A.9 180 fpm Air Only/Offgas Iine Disconnected A.35

Figures

A.1 60 fpm Normal Case Flowrates Before and After SBS

A.2 60 fpm Normal Case Total SBS Pressure Drop A. 5

A.3 60 fpm Normal Case Offgas Inlet and Outlet Temperatures A. 6

A.4 62 fpm Surge Case Flowrates Before and After SBS . A. 8

A.5 62 fpm Surge Case Total SBS Pressure Drop A. A

A. $662 \mathrm{fpm}$ Surge Case Offgas Inlet and Outlet Temperatures A.10

A.7 51.2 sfpm Normal Case Flow Before and After SBS A. 12

A.8 51.2 sfpm Normal Case Total SBS Pressure Drop $\quad$ A.13

A.9 $51.2 \mathrm{sfpm}$ Normal Case Offgas Inlet and Outlet Temps A.14

A.10 51.2 sfpm Surge Case Flow Before and After SBS A.16

A.11 51.2 sfpm Surge Case Total SBS Pressure Drop $\quad$ A.17

A.12 51.2. sfpm Surge Case Offgas Inlet and Outlet Temps A.18

A.13 51.2 sfpm Surge Case (Repeat) Offgas Flow A. 20

A.14 51.2 sfpm Surge Case (Repeat) Total SBS Pressure Drop A.21

A.15 51.2 sfpm Surge Case (Repeat) Offgas In and Out Temps A.22

A.16 $120 \mathrm{fpm}$ Normal Case Flowrates Before and After SBS A.24

A.17 120 fpm Normal Case Total SBS Pressure Drop $\quad$ A.25

A.18 120 fpm Normal Case Offgas Inlet and Outlet Temps A.26

A. $19120 \mathrm{fpm}$ Surge Case Flowrates Before and After SBS A.28

A.20 $120 \mathrm{fpm}$ Surge Case Total SBS Pressure Drop A.29

A.21 $120 \mathrm{fpm}$ Surge Case Offgas Inlet and Outlet Temps A.30

A.22 $180 \mathrm{fpm}$ No Steam Case Flowrates Before and After SBS A.32

A.23 $180 \mathrm{fpm}$ No Steam Case total SBS Pressure Drop $\quad$ A.33

A.24 $180 \mathrm{fpm}$ No Steam Case Offgas Inlet and Outlet Temps A.34

A.25 $180 \mathrm{fpm}$ No Steam/Offgas Iine Disconnected-Flows A.36

A.26 $180 \mathrm{fpm}$ No Steam/Offgas Iine Disconnected- SBS DP $A .37$

A.27 $180 \mathrm{fpm}$ No Steam/Offgas Iine Disconnected- Temperature A.38 
This appendix provides the data for each case examined in data need 3.2. Each case is summarized by one table. The data in these tables was used to provide the information presented in Table 2.1 Following each table is a series of figures which show key variables as a function of time during the data collection period. The data in the tables is derived from the data shown in the plots. The cases are labeled by the SBS superficial bed velocity in $\mathrm{ft} / \mathrm{min}$ followed by the steam rate in $1 \mathrm{~b} / \mathrm{h} \mathrm{ft}^{2}$. The SBS bed cross-sectional area is taken as $6.8 \mathrm{ft}^{2}$ and the superficial velocity is calculated at exit conditions. The date shown with each table indicates when the data was collected and is provided to improve data traceability. 
Table A.1: $60 \mathrm{fpm}$ Air, $29 \mathrm{lb} / \mathrm{h} \mathrm{ft}^{2}$ Steam, Normal Case, $6 / 17 / 92$

\begin{tabular}{||l|c|c|c|c||}
\hline \hline & Target & Average & $\mathrm{Min}^{1}$ & $\mathrm{Max}^{1}$ \\
\hline $\begin{array}{l}\text { Air Superficial } \\
\text { Velocity }\end{array}$ & $60 \mathrm{fpm}$ & $62.8 \mathrm{fpm}$ & -5 & - \\
\hline Steam Flow Rate & $\begin{array}{c}29 \\
\text { Ib/h. } \mathrm{ft}^{2}\end{array}$ & $\begin{array}{c}1 \mathrm{27.3} \\
1 \mathrm{~b} / \mathrm{h} . \mathrm{ft}^{2}\end{array}$ & - & - \\
\hline SBS_DP & $\mathrm{N} / \mathrm{A}$ & $48.4^{\prime \prime} \mathrm{H}_{2} \mathrm{O}$ & $\begin{array}{c}46.1^{\prime \prime} \\
\cdot \mathrm{H}_{2} \mathrm{O}\end{array}$ & $\begin{array}{c}51.2^{\prime \prime} \\
\mathrm{H}_{2} \mathrm{O}\end{array}$ \\
\hline Corrected SBS DP & $\mathrm{N} / \mathrm{A}$ & $41.3^{\prime \prime} \mathrm{H}_{2} \mathrm{O}$ & - & - \\
\hline $\begin{array}{l}\text { Gas Inlet } \\
\text { Temperature }\end{array}$ & $\mathrm{N} / \mathrm{A}$ & $367.0^{\circ} \mathrm{C}$ & - & - \\
\hline $\begin{array}{l}\text { Gas Outlet } \\
\text { Temperature }\end{array}$ & $\mathrm{N} / \mathrm{A}$ & $51.3^{\circ} \mathrm{C}$ & - & - \\
\hline $\begin{array}{l}\text { SBS Average } \\
\text { Temperature }\end{array}$ & $51.7^{\circ} \mathrm{C}$ & $52.5^{\circ} \mathrm{C}$ & - & - \\
\hline
\end{tabular}

1. Minima and maxima over 1 minute intervals were averaged during the data collection period.

2. Superficial air-only velocity in SBS bed evaluated at exit conditions (ACFM/Bed Area). The value reported represents an average of the estimates made based on the SBS entrance and exit flows.

3. Value of SBS DP with the chevron demister pressure drop subtracted.

4. An average of all 27 thermocouples, averaged over the duration of the data collection period.

5. - No data available. 


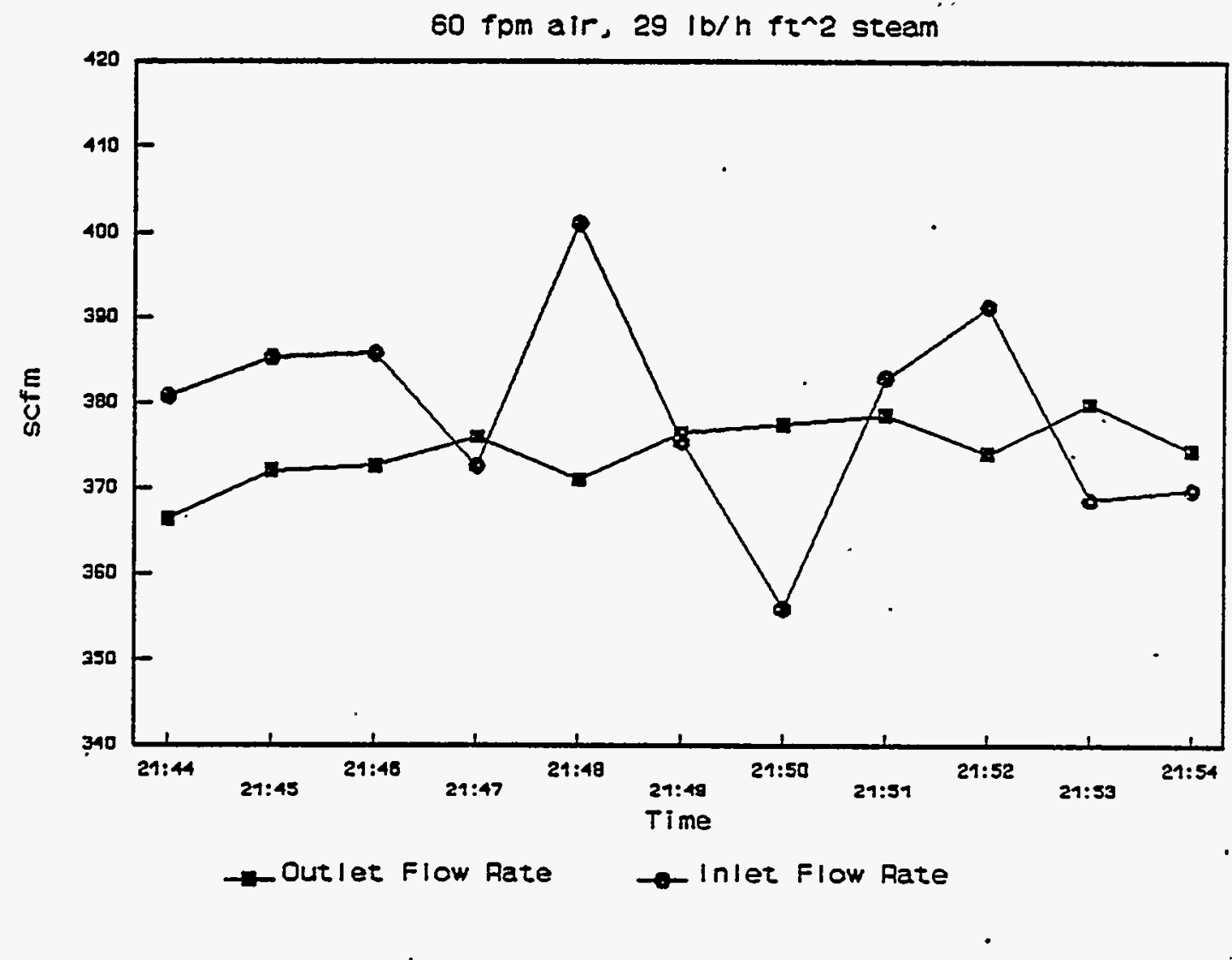

Figure A.I Flowrates At the SBS Inlet and SBS Exit vs Time. Averages over data collection period: Inlet 380 scfm, Outlet 375 scfm.

A. 4 
$60 \mathrm{fpm} a \mathrm{lr}, 29 \mathrm{lb} / \mathrm{h}$ ft^2 steam

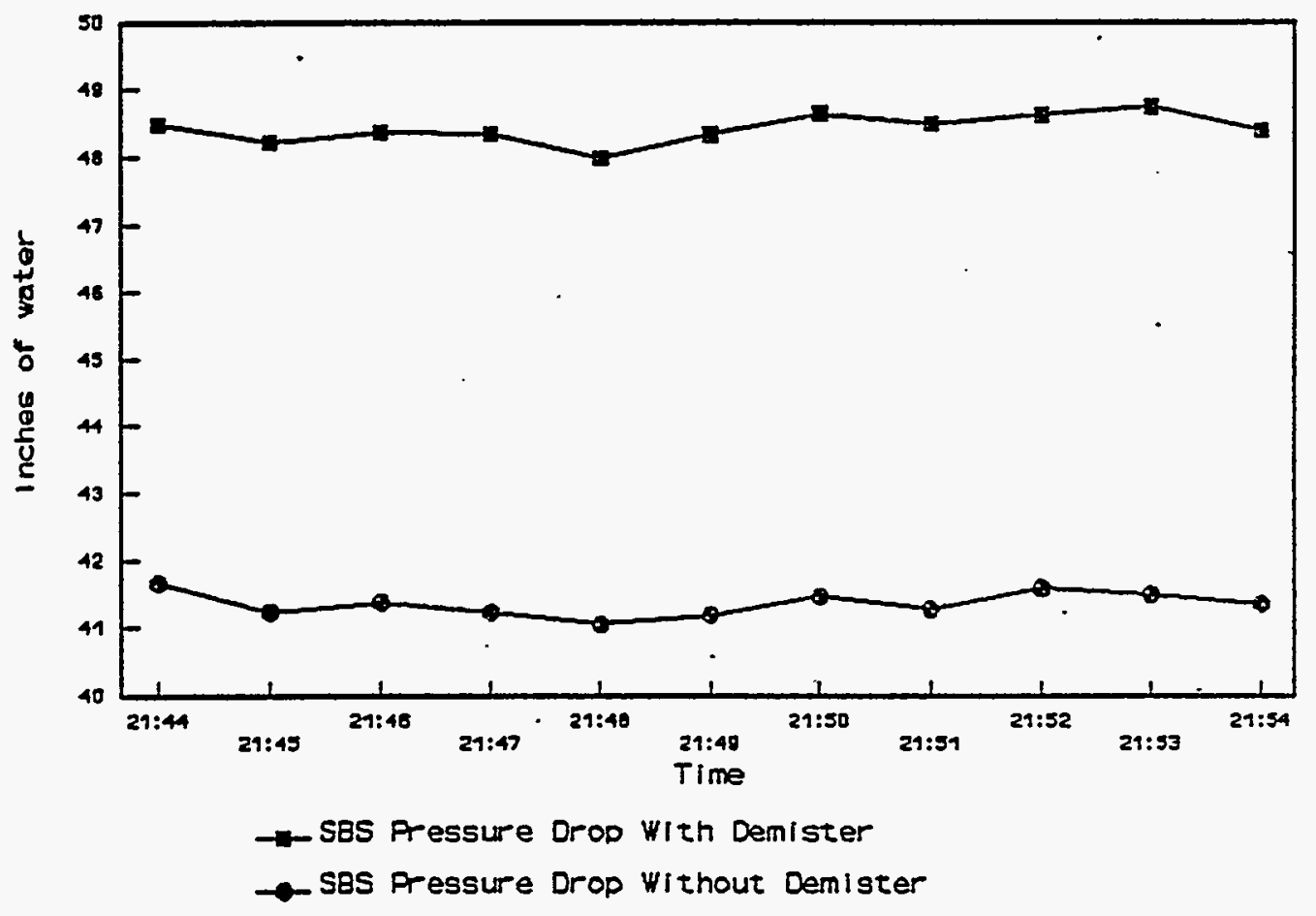

FIGURE A.2 SBS Pressure Drop vs. Time With and Without the Effect of the Chevron Demister. Average values: with demister 48.4 in. WC without demister 41.3 in. WC

A. 5 


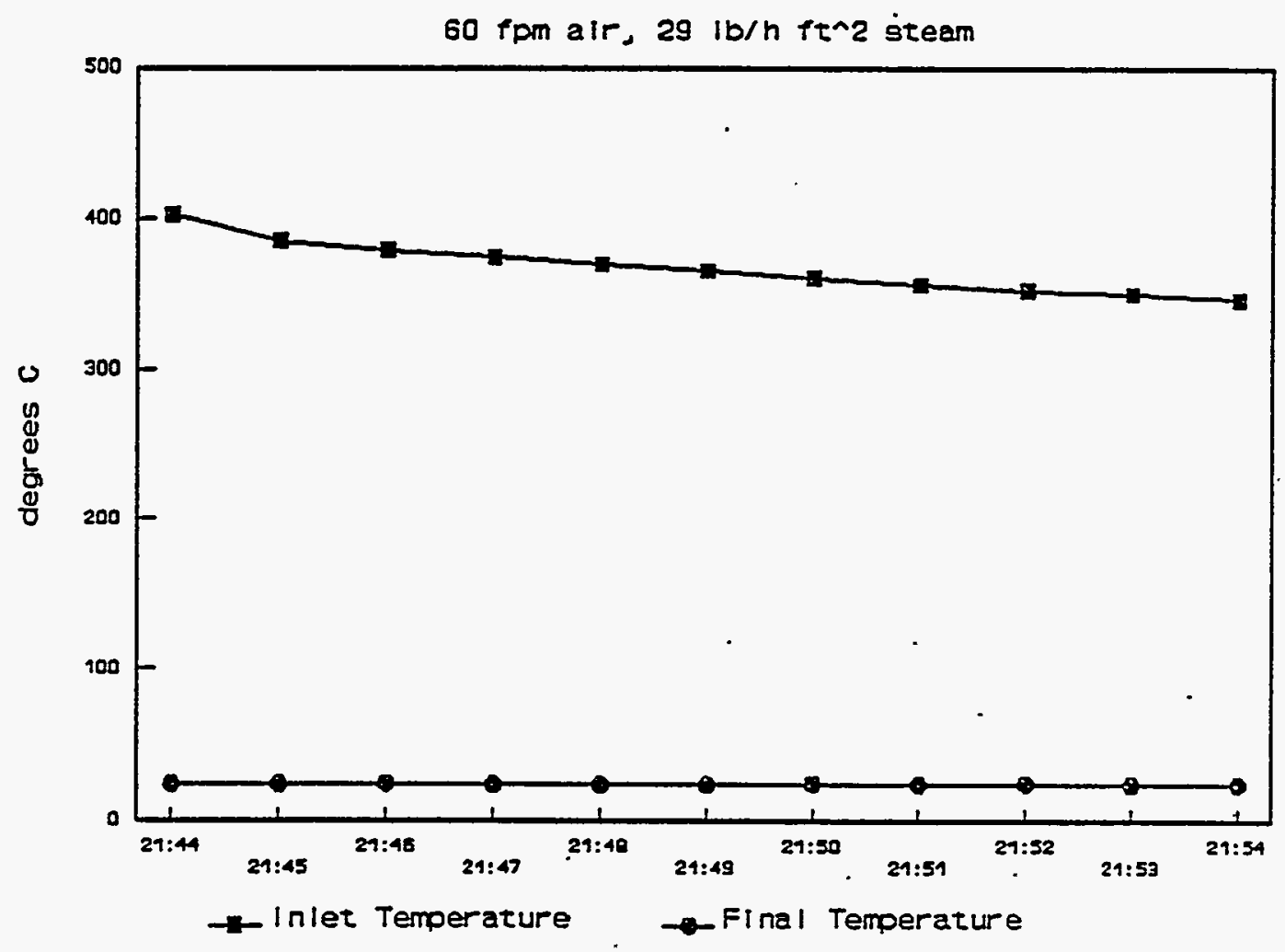

FIGURE A.3 Offgas Inlet and Outlet Temperatures. Average over data collection period: Inlet $367.0^{\circ} \mathrm{C}$

Outlet $23.8^{\circ} \mathrm{C}$

A. 6 
Table A.2: $60 \mathrm{fpm}$ Air, $201 \mathrm{lb} / \mathrm{h} \mathrm{ft^{2 }}$ Steam, Surge Case, 6/25/92

\begin{tabular}{||l|c|c|c|c||}
\hline & Target & Average & Begin $^{2}$ & End $^{1}$ \\
\hline $\begin{array}{l}\text { Air Superficial } \\
\text { Velocity }\end{array}$ & $60 \mathrm{fpm}$ & $80.9 \mathrm{fpm}$ & $82.7 \mathrm{fpm}$ & $78.6 \mathrm{fpm}$ \\
\hline Steam Flow Rate & $\begin{array}{c}20 \mathrm{I} \\
1 \mathrm{~b} / \mathrm{h} . \mathrm{ft}^{2}\end{array}$ & $\begin{array}{c}199.3 \\
1 \mathrm{~b} / \mathrm{h} . \mathrm{ft}^{2}\end{array}$ & $\begin{array}{c}200.0 \\
1 \mathrm{~b} / \mathrm{h} . \mathrm{ft}^{2}\end{array}$ & $\begin{array}{c}198.8 \\
1 \mathrm{~b} / \mathrm{h} . \mathrm{ft}^{2}\end{array}$ \\
\hline SBS DP & $\mathrm{N} / \mathrm{A}$ & $56.9^{n} \mathrm{H}_{2} \mathrm{O}$ & $56.3^{\prime \prime} \mathrm{H}_{2} \mathrm{O}$ & $57.2^{\prime \prime} \mathrm{H}_{2} \mathrm{O}$ \\
\hline Corrected SBS DP & $\mathrm{N} / \mathrm{A}$ & $46.3^{\prime \prime} \mathrm{H}_{2} \mathrm{O}$ & $46.4^{\prime \prime} \mathrm{H}_{2} \mathrm{O}$ & $46.1^{\prime \prime} \mathrm{H}_{2} \mathrm{O}$ \\
\hline $\begin{array}{l}\text { Gas Inlet } \\
\text { Temperature }\end{array}$ & $\mathrm{N} / \mathrm{A}$ & $347.6^{\circ} \mathrm{C}$ & $359.1^{\circ} \mathrm{C}$ & $332.6^{\circ} \mathrm{C}$ \\
\hline $\begin{array}{l}\text { Gas Outlet } \\
\text { Temperature }\end{array}$ & $\mathrm{N} / \mathrm{A}$ & $50.1^{\circ} \mathrm{C}$ & $40.5^{\circ} \mathrm{C}$ & $57.8^{\circ} \mathrm{C}$ \\
\hline $\begin{array}{l}\text { SBS Average } \\
\text { Temperature }\end{array}$ & $\mathrm{N} / \mathrm{A}$ & $51.9^{\circ} \mathrm{C}$ & $42.6^{\circ} \mathrm{C}$ & $59.3^{\circ} \mathrm{C}$ \\
\hline
\end{tabular}

1. Averages for the first and last minute, respectively, of data collection.

2. Superficial air-only velocity in SBS bed evaluated at exit conditions (ACFM/Bed Area). The value reported represents an average of the estimates made based on the SBS entrance and exit flows.

3. Value of SBS DP with the chevron demister pressure drop subtracted.

4. An average of all 27 thermocouples, averaged over the duration of the data collection period. 


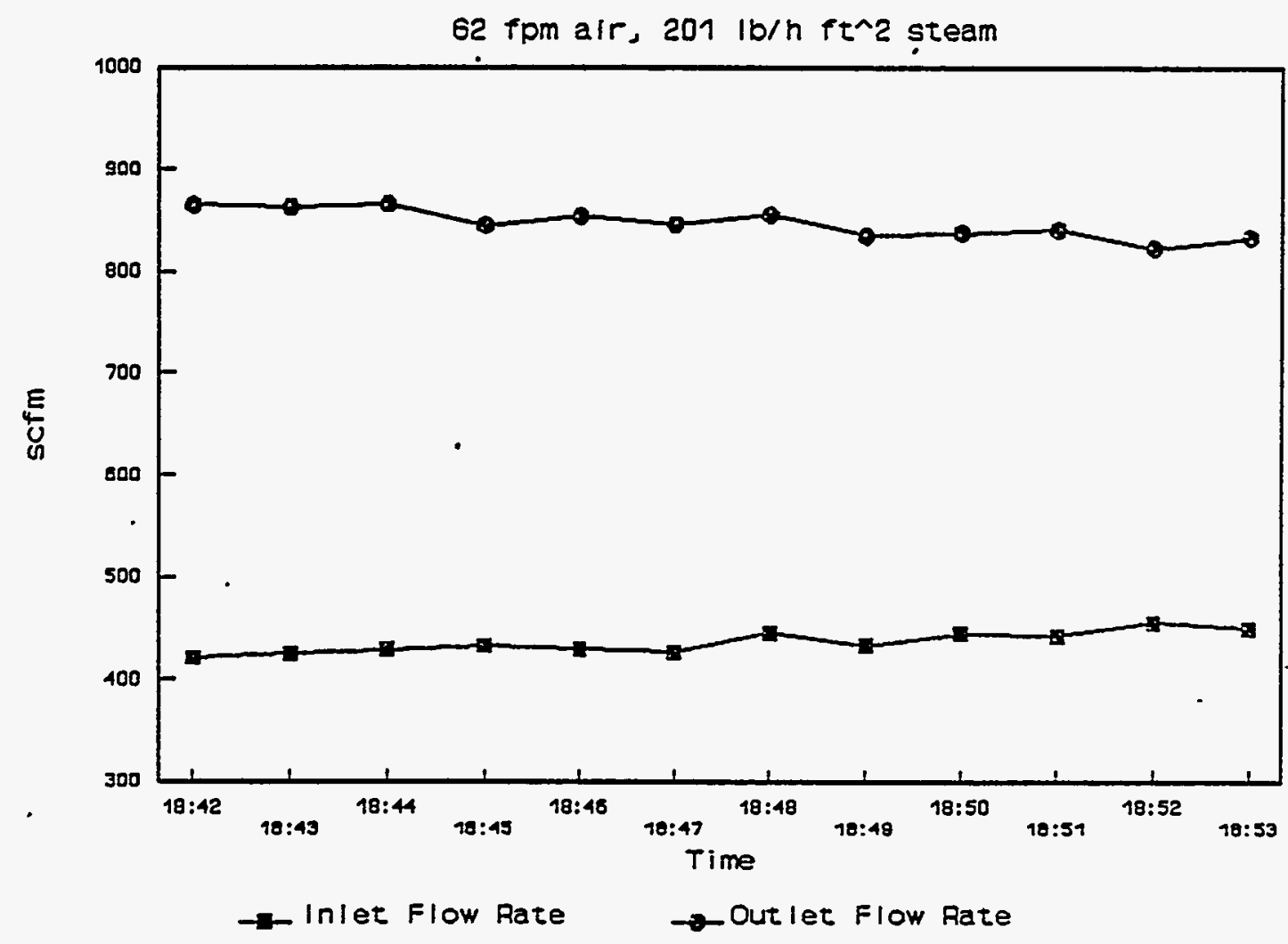

FIGURE A.4 Offgas Flowrates At the SBS Inlet and Exit. Averages over data collection period:

Inlet: 846.2 scfm

Outlet: $436.2 \mathrm{scfm}$

A. 8 


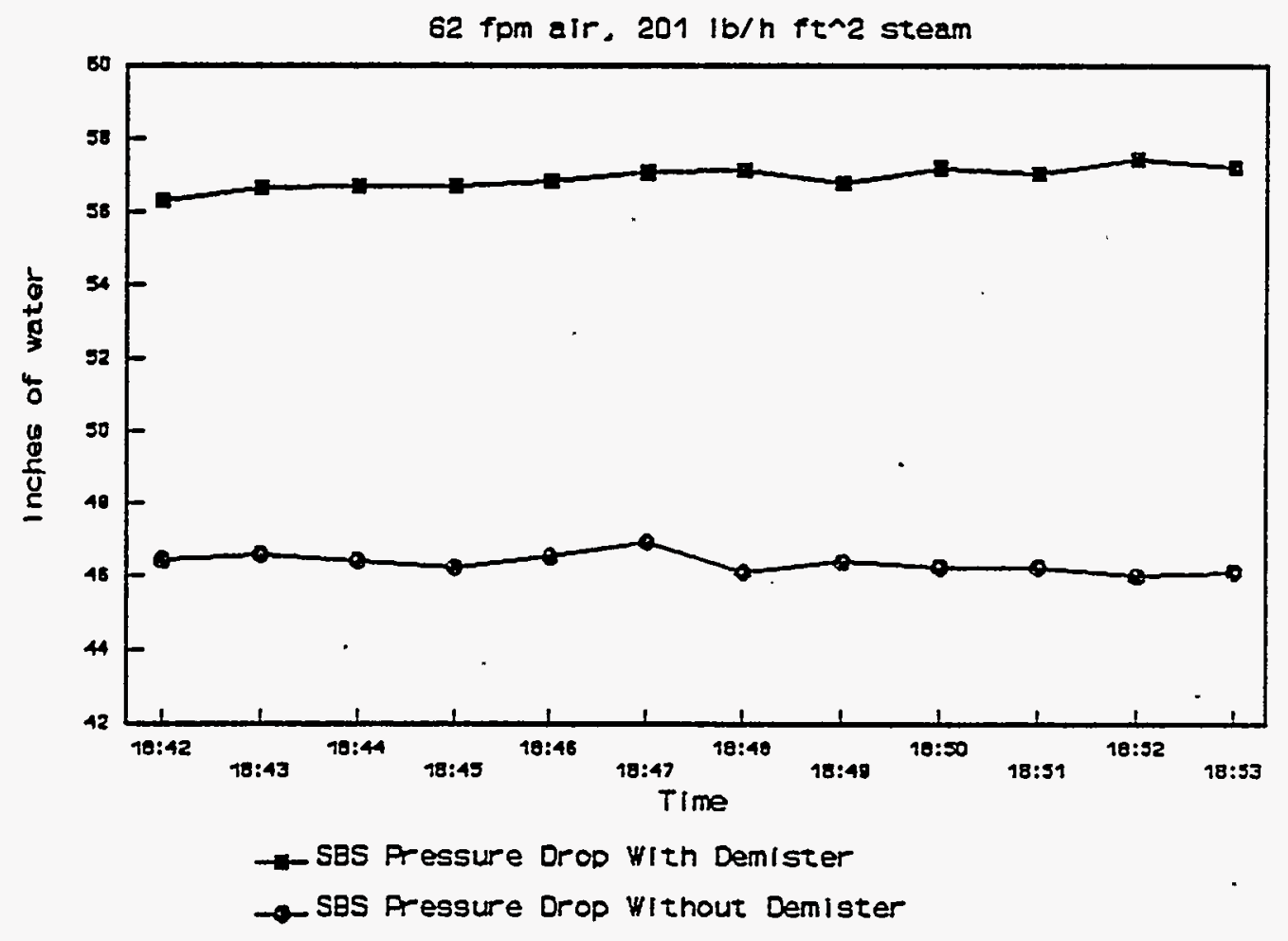

FIGURE A.5 SBS Pressure Drop vs. Time With and Without the Effect of the Chevron Demister. Average values: with demister 56.9 in. WC without demister 46.3 in. WC

A. 9 


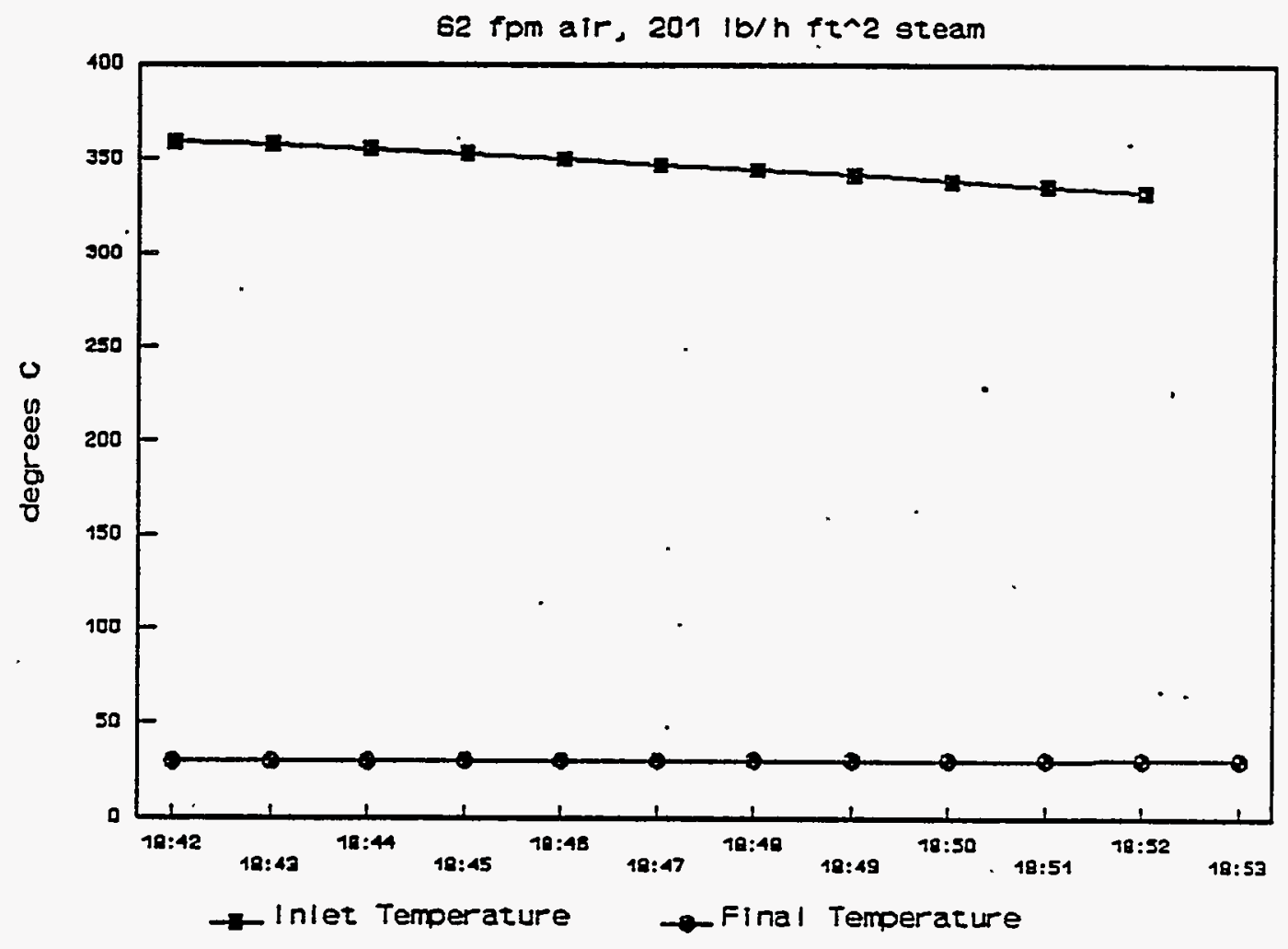

FIGURE A.6 Offgas Temperature at the SBS Inlet and Outlet. Average values over data collection period:

Inlet $347.6^{\circ} \mathrm{C}$

Outlet $50.1^{\circ} \mathrm{C}$ 
Important Note: The conditions specified below result in a slightly evaporating condition in the SBS. The water leaving the SBS in the saturated exit gas is greater than the steam supplied from the melter. Because of this, Figure A.7 shows a greater exit flowrate than the entrance flowrate. This may have contributed to the reduction in SBS pressure drop over the test period. If utilized in HWVP, this condition will require a makeup water supply to the SBS.

Table A.3: $51.2 \mathrm{sfpm}$ Air, $29 \mathrm{lb} / \mathrm{h} \mathrm{\textrm {ft } ^ { 2 }}$ Steam, Normal Case, 6/17/92

\begin{tabular}{|c|c|c|c|c|}
\hline & Target & Average & $\operatorname{Min}$ & $\operatorname{Max}^{1}$ \\
\hline $\begin{array}{l}\text { Air Superficial } \\
\text { Velocity }\end{array}$ & $\begin{array}{l}51.2 \\
\text { sfpm } \\
\end{array}$ & $53.6 \mathrm{sfpm}$ & -5 & - \\
\hline Steam Flow Rate & $\begin{array}{l}29 \\
1 b / h \cdot f t^{2}\end{array}$ & $\begin{array}{c}26.8 \\
1 b / h \cdot f t^{2} \\
\end{array}$ & - & - \\
\hline SBS DP & $N / A$ & $52.5 " \mathrm{H}_{2} \mathrm{O}$ & $50.9 " \mathrm{H}_{2} \mathrm{O}$ & $54.4 " \mathrm{H}_{2} \mathrm{O}$ \\
\hline Corrected SBS $\mathrm{DP}^{3}$ & $N / A$ & $42.7 " \mathrm{H}_{2} \mathrm{O}$ & - & - \\
\hline $\begin{array}{l}\text { Gas Inlet } \\
\text { Temperature }\end{array}$ & $\mathrm{N} / \mathrm{A}$ & $315.7^{\circ} \mathrm{C}$ & - & - \\
\hline $\begin{array}{l}\text { Gas Outlet } \\
\text { Temperature }\end{array}$ & $\mathrm{N} / \mathrm{A}$ & $52.0^{\circ} \mathrm{C}$ & - & - \\
\hline $\begin{array}{l}\text { SBS Average } \\
\text { Temperature }\end{array}$ & $51.7^{\circ} \mathrm{C}$ & $52.6^{\circ} \mathrm{C}$ & - & - \\
\hline
\end{tabular}

1. Minima and maxima over 1 minute intervals were averaged during the data collection period.

2. Superficial air-only velocity in SBS bed evaluated at exit conditions (ACFM/Bed Area). The value reported represents an average of the estimates made based on the SBS entrance and exit flows.

3. Value of SBS DP with the chevron demister pressure drop subtracted.

4. An average of all 27 thermocouples, averaged over the duration of the data collection period.

5. - No data available. 


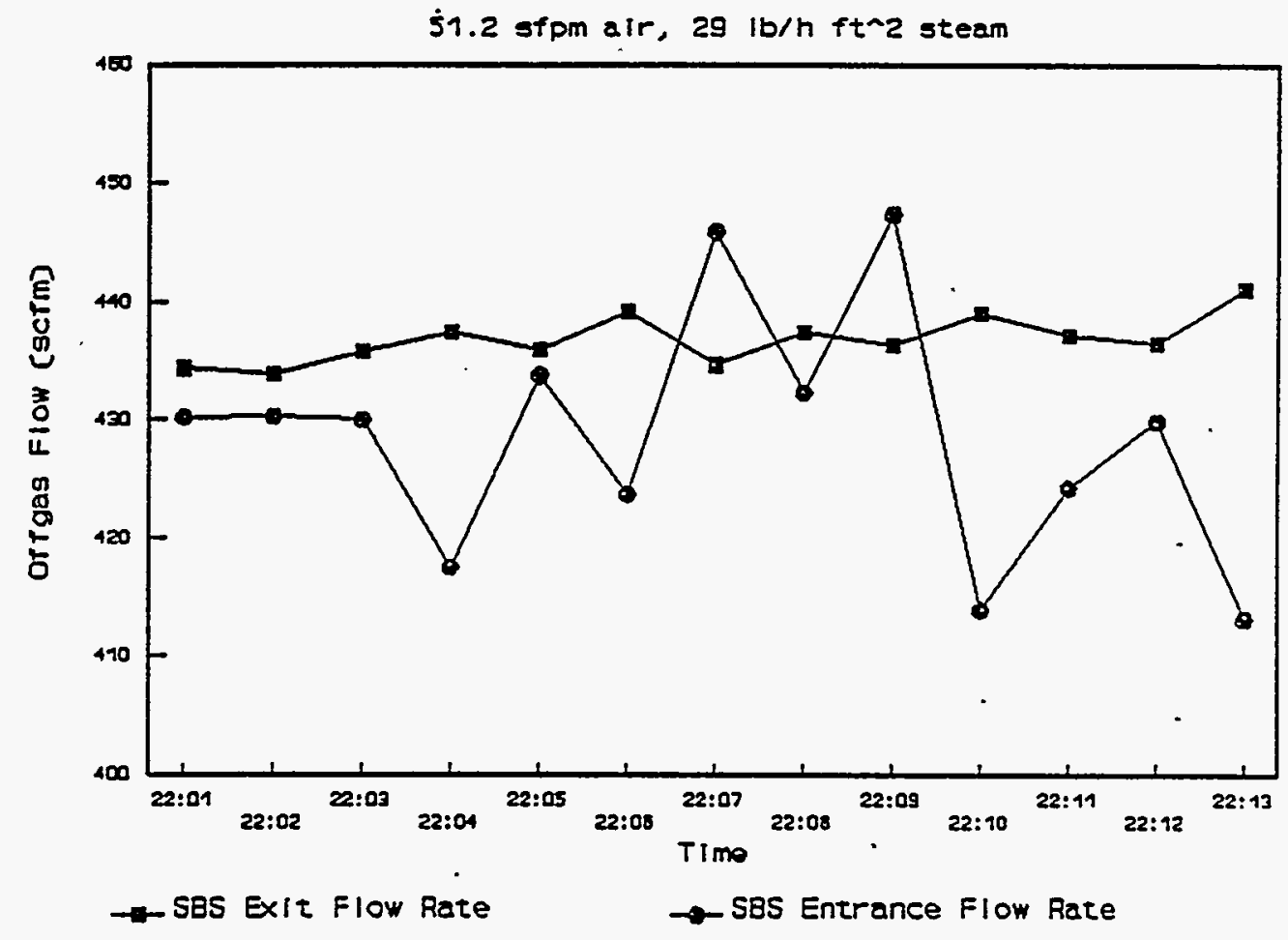

FIGURE A.7

Offgas Flowrates At SBS Entrance and Exit vs. Time. Averages over the data collection period:

Inlet $428.6 \mathrm{scfm}$

Outlet $436.8 \mathrm{scfm}$

\section{A. 12}




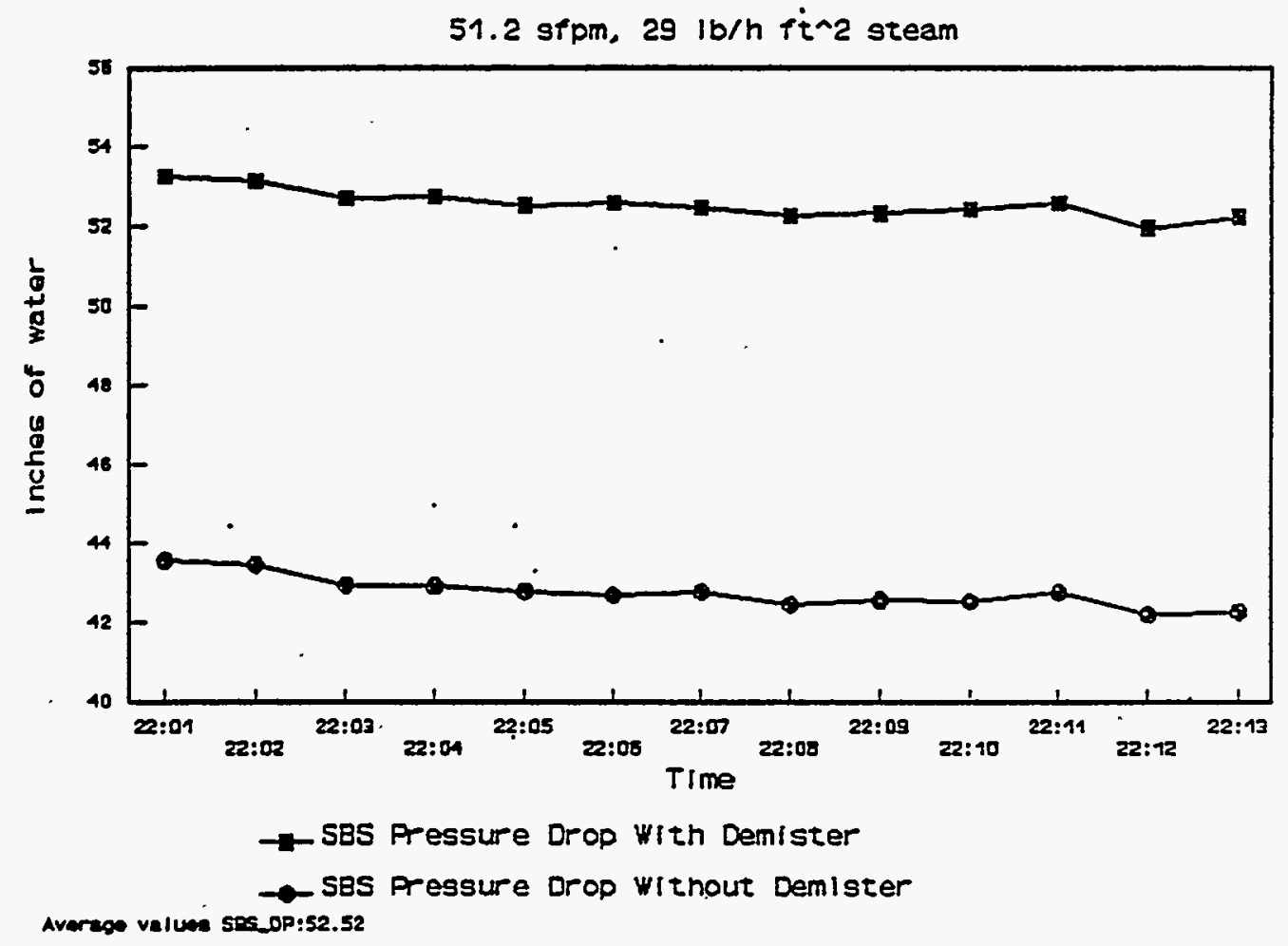

FIGURE A.8 SBS Pressure Drop vs. Time With and Without the Effect of the Cherron Demister. Average values: with demister 52.5 in. WC without demister 42.7 in. WC

A. 13 


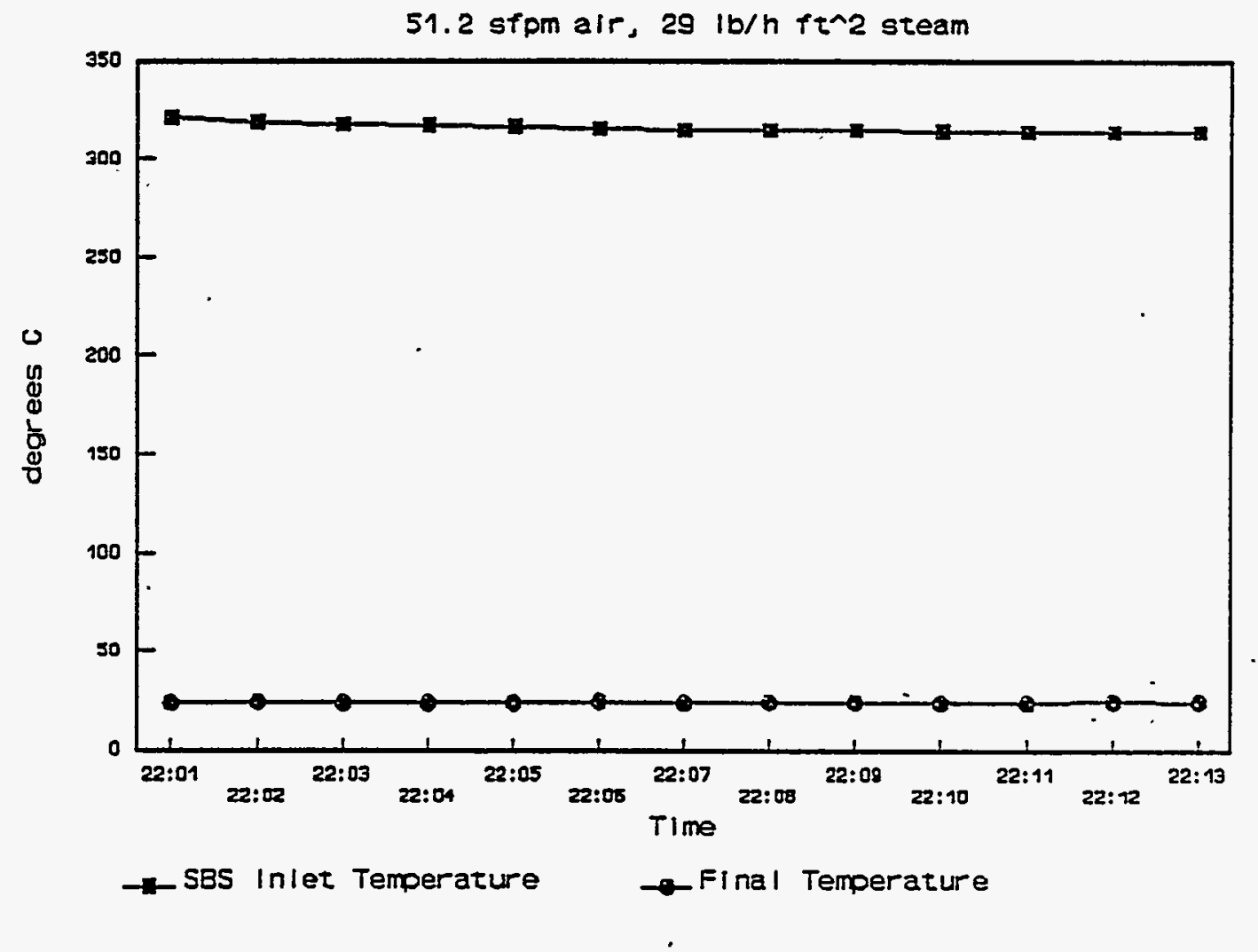

FIGURE A.9. Offgas Inlet and outlet Temperatures vs Time. The average values over the data collection period: Inlet $315.7^{\circ} \mathrm{C}$

Outlet $23.9^{\circ} \mathrm{C}$

A. 14 
Table A.4: 51.2 sfpm Air, $201 \mathrm{lb} / \mathrm{h} \mathrm{ft^{2 }}$ Steam, Surge Case, 6/17/92

\begin{tabular}{|c|c|c|c|c|}
\hline & Target & Average & Begin ${ }^{1}$ & End ${ }^{1}$ \\
\hline $\begin{array}{l}\text { Air Superficial } \\
\text { Velocity }\end{array}$ & $51.2 \mathrm{sfpm}$ & $54.3 \mathrm{sfpm}$ & $56.2 \mathrm{sfpm}$ & $55.5 \mathrm{sfpm}$ \\
\hline Steam Flow Rate & $\begin{array}{c}201 \\
1 b / h . f t^{2}\end{array}$ & $\begin{array}{c}189.1 \\
I \mathrm{~b} / \mathrm{h} . \mathrm{ft} \mathrm{t}^{2}\end{array}$ & $\begin{array}{c}189.3 \\
1 \mathrm{~b} / \mathrm{h} . \mathrm{ft}^{2}\end{array}$ & $\begin{array}{c}189.7 \\
1 \mathrm{~b} / \mathrm{h} . \mathrm{ft}^{2}\end{array}$ \\
\hline SBS_DP & $\mathrm{N} / \mathrm{A}$ & $62.7^{n} \mathrm{H}_{2} \mathrm{O}$ & $61.7 " \mathrm{H}_{2} \mathrm{O}$ & $62.9 " \mathrm{H}_{2} \mathrm{O}$ \\
\hline $\begin{array}{l}\text { Coprected SBS } \\
\text { DP }\end{array}$ & $\mathrm{N} / \mathrm{A}$ & $43.1 " \quad \mathrm{H}_{2} \mathrm{O}$ & $42.7 " \quad \mathrm{H}_{2} \mathrm{O}$ & $43.6 " \mathrm{H}_{2} \mathrm{O}$ \\
\hline $\begin{array}{l}\text { Gas Inlet } \\
\text { Temperature }\end{array}$ & $\mathrm{N} / \mathrm{A}$ & $304.1^{\circ} \mathrm{C}$ & $323.8^{\circ} \mathrm{C}$ & $296.2^{\circ} \mathrm{C}$ \\
\hline $\begin{array}{l}\text { Gas Outlet } \\
\text { Temperature }\end{array}$ & $\mathrm{N} / \mathrm{A}$ & $68.2^{\circ} \mathrm{C}$ & $65.9^{\circ} \mathrm{C}$ & $68.0^{\circ} \mathrm{C}$ \\
\hline $\begin{array}{l}\text { SBS Average } \\
\text { Temperature }\end{array}$ & N/A & $6.9 .6^{\circ} \mathrm{C}$ & $68.1^{\circ} \mathrm{C}$ & $69.1^{\circ} \mathrm{C}$ \\
\hline
\end{tabular}

1. Averages for the first and last minute, respectively, of data collection.

2. Superficial air-only velocity in SBS bed evaluated at exit conditions (ACFM/Bed Area). The value reported represents an average of the estimates made based on the SBS entrance and exit flows.

3. Value of SBS DP with the chevron demister pressure drop subtracted.

4. An average of all 27 thermocouples, averaged over the duration of the data collection period. 


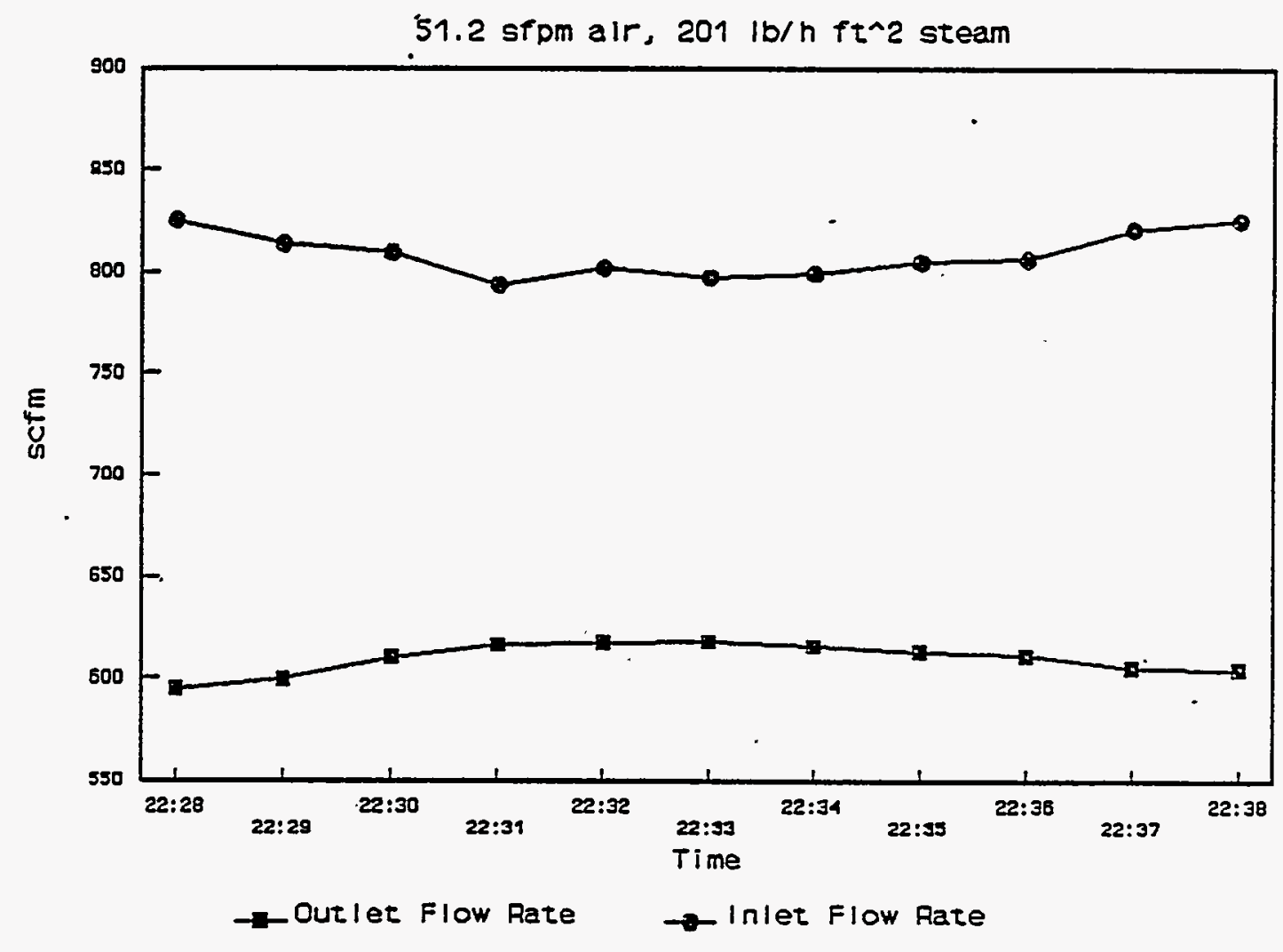

FIGURE A.10 Offgas Flowrates at the SBS Inlet and Exit vs. Time. Average values over the data collection period:

Inlet $808.7 \mathrm{scfm}$

Outlet $609.5 \mathrm{scfm}$

A. 16 


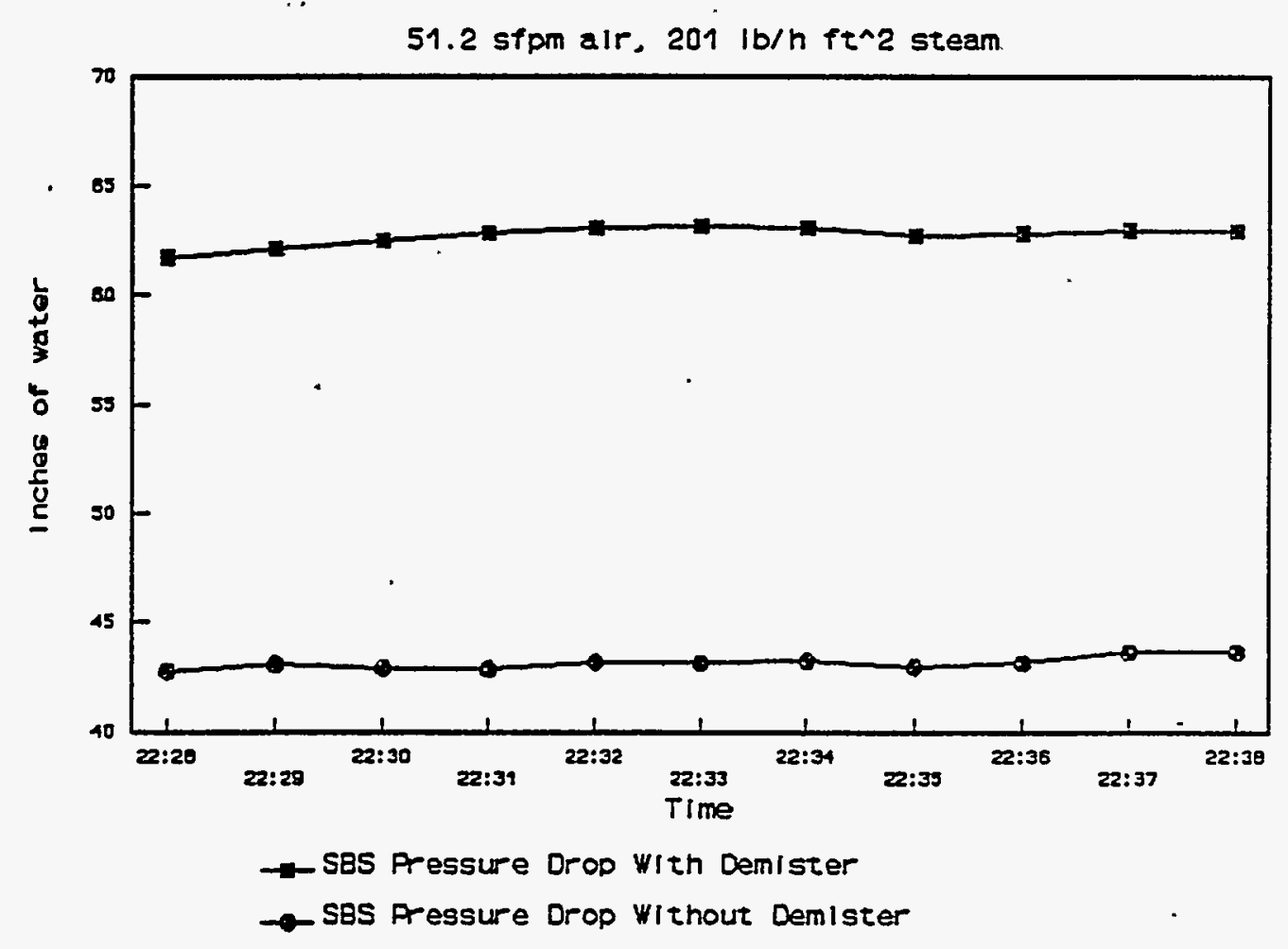

FIGURE A.11 SBS Pressure Drop vs. Time With and without the Effect of the Chevron Demister. Average values: with demister 62.7 in. WC without demister 43.1 in. WC 


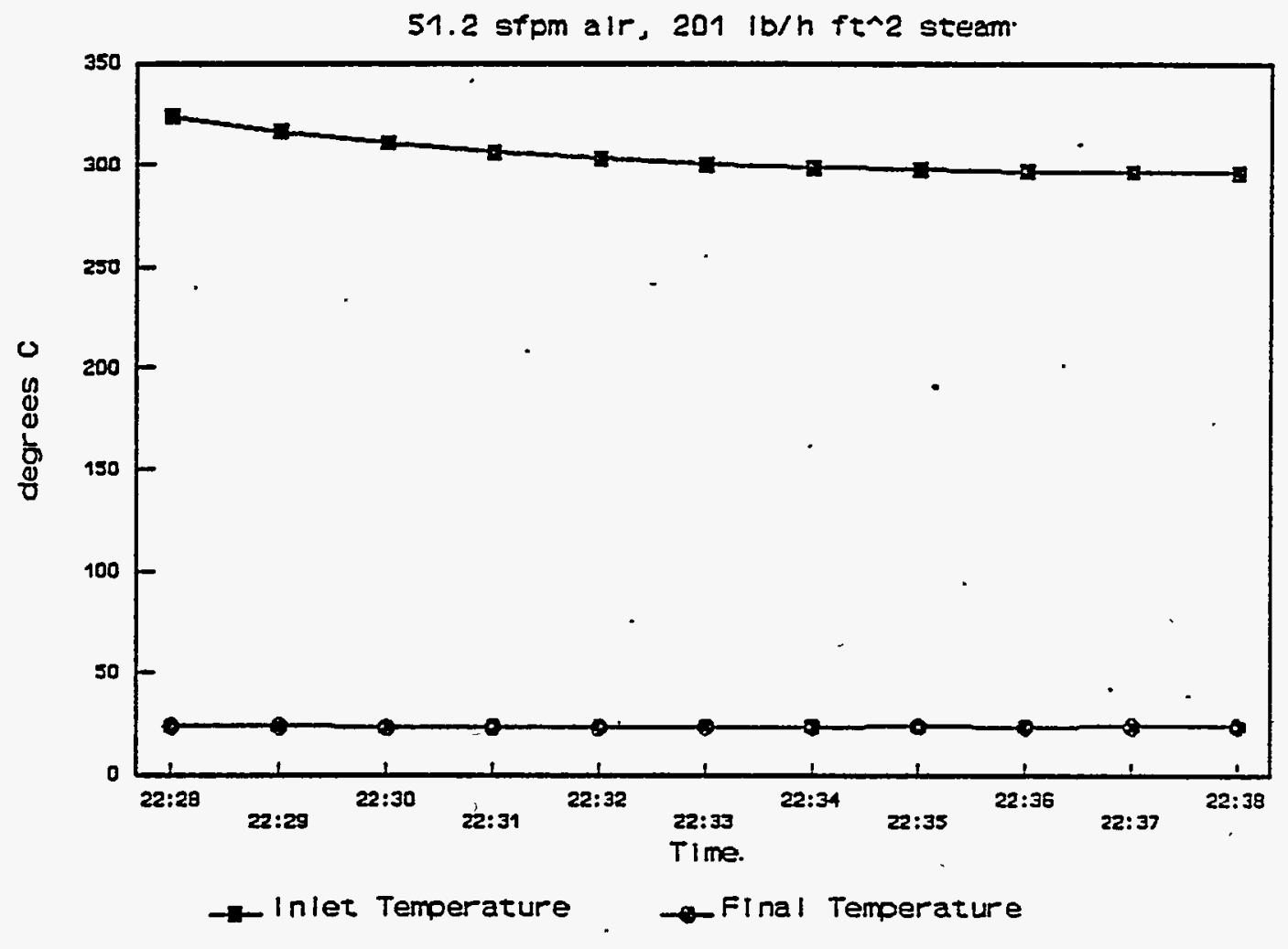

FIGURE A.12 Offgas Temperature at SBS Inlet and outlet vs. Time. Average values over data collection period:

Inlet: $304.1^{\circ} \mathrm{C}$

Outlet: $23.4^{\circ} \mathrm{C}$ 
Table A.5: $51.2 \mathrm{sfpm}, 201 \mathrm{lb} / \mathrm{h} \mathrm{ft}^{2}$, Surge Case (Repeat), 6/25/92

\begin{tabular}{|l|c|c|c|c||}
\hline & Target & Average & Begin $^{1}$ & End $^{1}$ \\
\hline $\begin{array}{l}\text { Air Superficial } \\
\text { Velocity }\end{array}$ & $\begin{array}{c}51.2 \\
\text { sfpm }\end{array}$ & 62.4 sfpm & 64.6 sfpm & 60.5 sfpm \\
\hline Steam Flow Rate & $\begin{array}{c}201 \\
1 \mathrm{~b} / \mathrm{h} . \mathrm{ft}^{2}\end{array}$ & $\begin{array}{c}199.5 \\
1 \mathrm{~b} / \mathrm{h}: \mathrm{ft}^{2}\end{array}$ & $\begin{array}{c}200.4 \\
1 \mathrm{~b} / \mathrm{h} . \mathrm{ft}^{2}\end{array}$ & $\begin{array}{c}199.0 \\
1 \mathrm{~b} / \mathrm{h}^{\mathrm{fft}}{ }^{2}\end{array}$ \\
\hline SBS DP & $\mathrm{N} / \mathrm{A}$ & $59.2^{\prime \prime} \mathrm{H}_{2} \mathrm{O}$ & $58.8^{\prime \prime} \mathrm{H}_{2} \mathrm{O}$ & $59.7^{\prime \prime} \mathrm{H}_{2} \mathrm{O}$ \\
\hline Corrected SBS DP & $\mathrm{N} / \mathrm{A}$ & $45.2^{\prime \prime} \mathrm{H}_{2} \mathrm{O}$ & $45.3^{\prime \prime} \mathrm{H}_{2} \mathrm{O}$ & $45.4^{\prime \prime} \mathrm{H}_{2} \mathrm{O}$ \\
\hline $\begin{array}{l}\text { Gas Inlet } \\
\text { Temperature }\end{array}$ & $\mathrm{N} / \mathrm{A}$ & $316.6^{\circ} \mathrm{C}$ & $326.5^{\circ} \mathrm{C}$ & $303.4^{\circ} \mathrm{C}$ \\
\hline $\begin{array}{l}\text { Gas Outlet } \\
\text { Temperature }\end{array}$ & $\mathrm{N} / \mathrm{A}$ & $47.1^{\circ} \mathrm{C}$ & $39.1^{\circ} \mathrm{C}$ & $53.8^{\circ} \mathrm{C}$ \\
\hline $\begin{array}{l}\text { SBS Average } \\
\text { Temperature }\end{array}$ & $\mathrm{N} / \mathrm{A}$ & $48.5^{\circ} \mathrm{C}$ & $40.2^{\circ} \mathrm{C}$ & $55.2^{\circ} \mathrm{C}$ \\
\hline
\end{tabular}

1. Averages for the first and last minute, respectively, of data collection.

2. Superficial air-only velocity in SBS bed evaluated at exit conditions (ACFM/Bed Area). The value reported represents an average of the estimates made based on the SBS entrance and exit flows.

3. Value of SBS DP with the chevron demister pressure drop subtracted.

4. An average of all 27 thermocouples, averaged over the duration of the data collection period. 


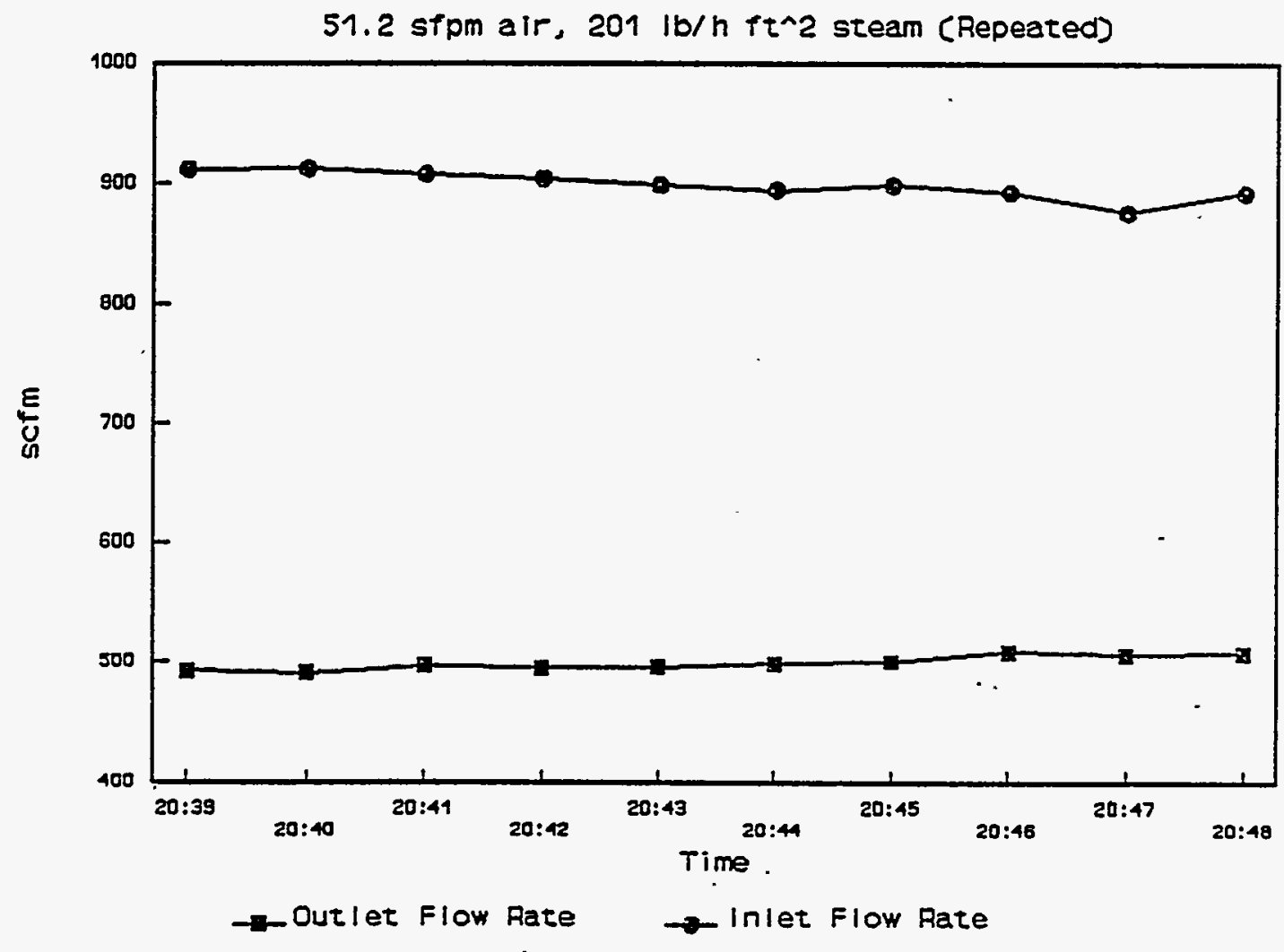

FIGURE A.13 Offgas Flowrates at SBS Inlet and Outlet vs. Time. Average values over data collection period:

Inlet $898.1 \mathrm{scfm}$

Outlet $498.8 \mathrm{scfm}$ 
52.2 sfpm air, $201 \mathrm{lb} / \mathrm{h}$ Tt^2 steam

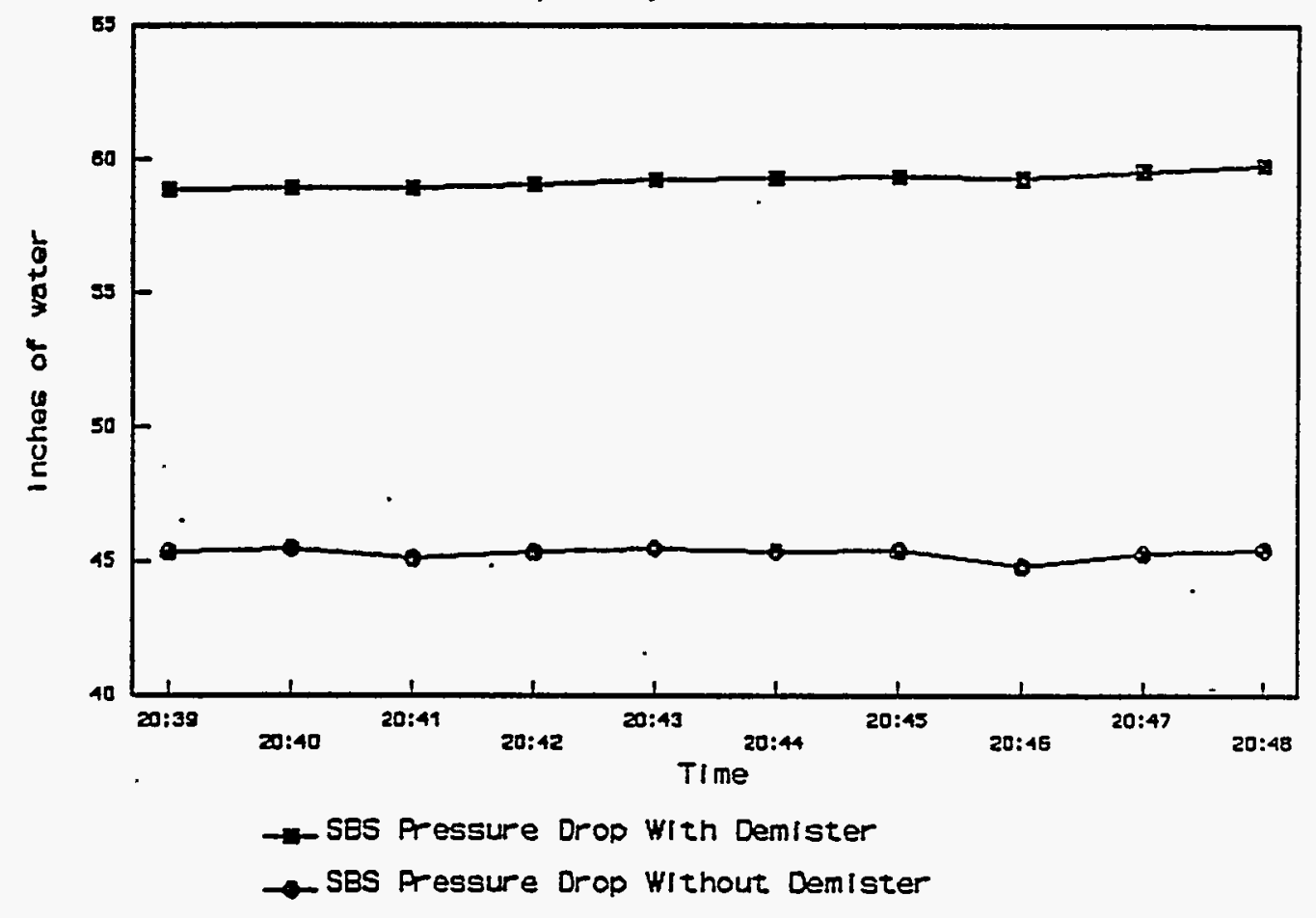

FIGURE A.14 SBS Pressure Drop vs. Time with and without the Effect of the Chevron Demister. Average values: with demister 59.2 in. WC without demister 45.2 in. WC

A. 21 


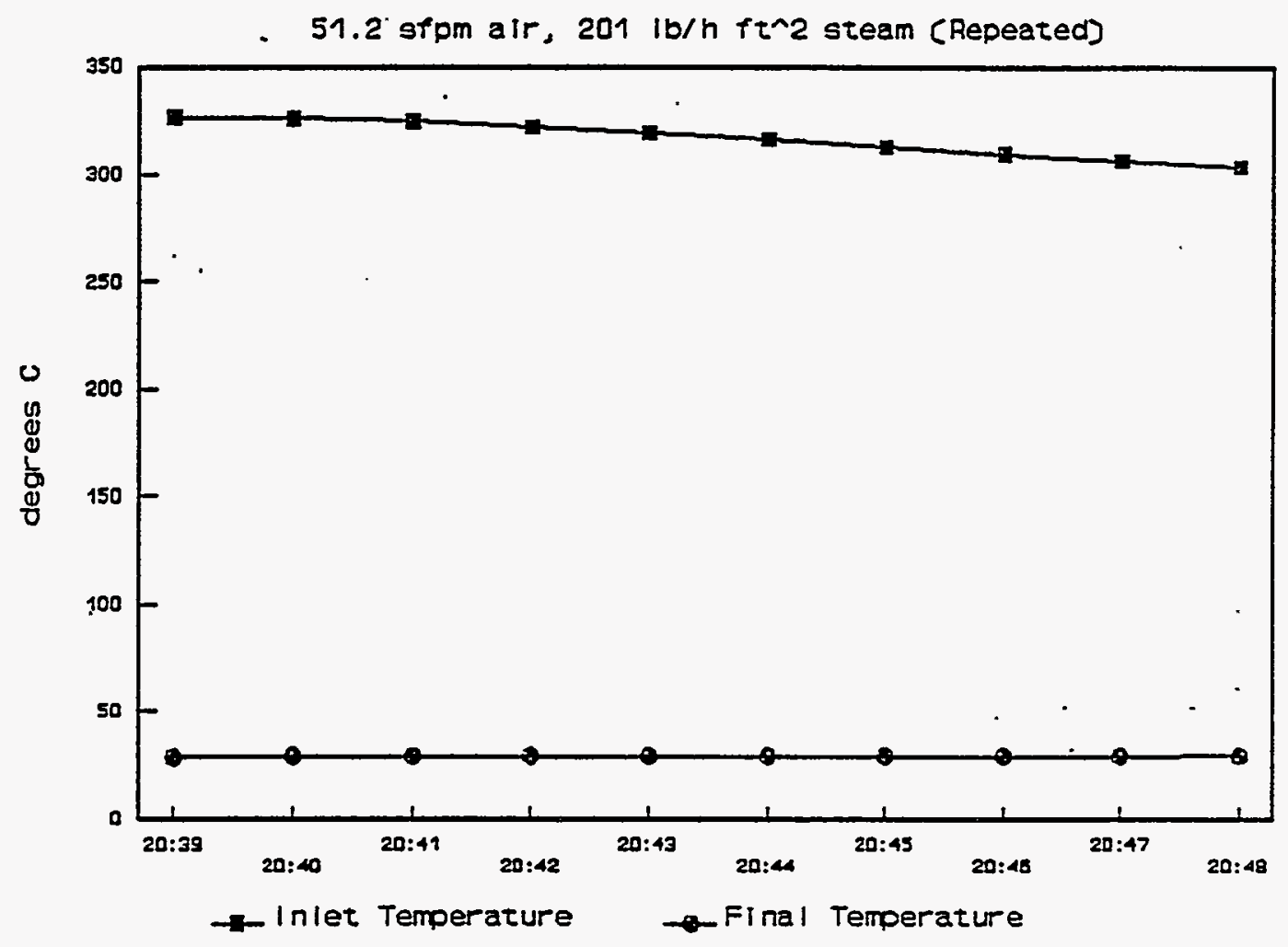

FIGURE A.15 Offgas Temperature and SBS Inlet and Outlet vs Time. Average values over data collection period: Inlet $316.6^{\circ} \mathrm{C}$ Outlet $29.1^{\circ} \mathrm{C}$

A. 22 
Table A.6: 120 fpm Air, 29 Ib/h $\mathrm{ft}^{2}$ Steam, Normal Case, 6/24/92

\begin{tabular}{|l|c|c|c|c|}
\hline & Target & Average & Min $^{1}$ & Max $^{1}$ \\
\hline $\begin{array}{l}\text { Air Superficial } \\
\text { Velocity }\end{array}$ & 120 fpm & $124.6 . \mathrm{fpm}$ & $-{ }^{5}$ & - \\
\hline Steam Flow Rate & $\begin{array}{c}29 \\
1 \mathrm{~b} / \mathrm{h} . \mathrm{ft}^{2}\end{array}$ & $\begin{array}{c}29.4 \\
1 \mathrm{~b} / \mathrm{h}^{\circ} \mathrm{ft}^{2}\end{array}$ & - & - \\
\hline SBS DP & $\mathrm{N} / \mathrm{A}$ & $65.9^{\prime \prime} \mathrm{H}_{2} \mathrm{O}$ & $63.6^{\prime \prime} \mathrm{H}_{2} \mathrm{O}$ & $68.4^{\prime \prime} \mathrm{H}_{2} \mathrm{O}$ \\
\hline Corrected SBS $\mathrm{DP}^{3}$ & $\mathrm{~N} / \mathrm{A}$ & $41.4^{\prime \prime} \mathrm{H}_{2} \mathrm{O}$ & - & - \\
\hline $\begin{array}{l}\text { Gas Inlet } \\
\text { Temperature }\end{array}$ & $\mathrm{N} / \mathrm{A}$ & $368.7^{\circ} \mathrm{C}$ & - & - \\
\hline $\begin{array}{l}\text { Gas Outlet } \\
\text { Temperature }\end{array}$ & $\mathrm{N} / \mathrm{A}$ & $51.4^{\circ} \mathrm{C}$ & - & - \\
\hline $\begin{array}{l}\text { SBS Average } \\
\text { Temperature }\end{array}$ & $51.7^{\circ} \mathrm{C}$ & $52.6^{\circ} \mathrm{C}$ & - & - \\
\hline
\end{tabular}

1. Minima and maxima over 1 minute intervals were averaged during the data collection period.

2. Superficial air-only velocity in SBS bed evaluated at exit conditions . (ACFM/Bed Area). The value reported represents an average of the estimates made based on the SBS entrance and exit flows.

3. Value of SBS DP with the chevron demister pressure drop subtracted.

4. An average of all 27. thermocouples, averaged over the duration of the data collection period.

5. - No data available. 


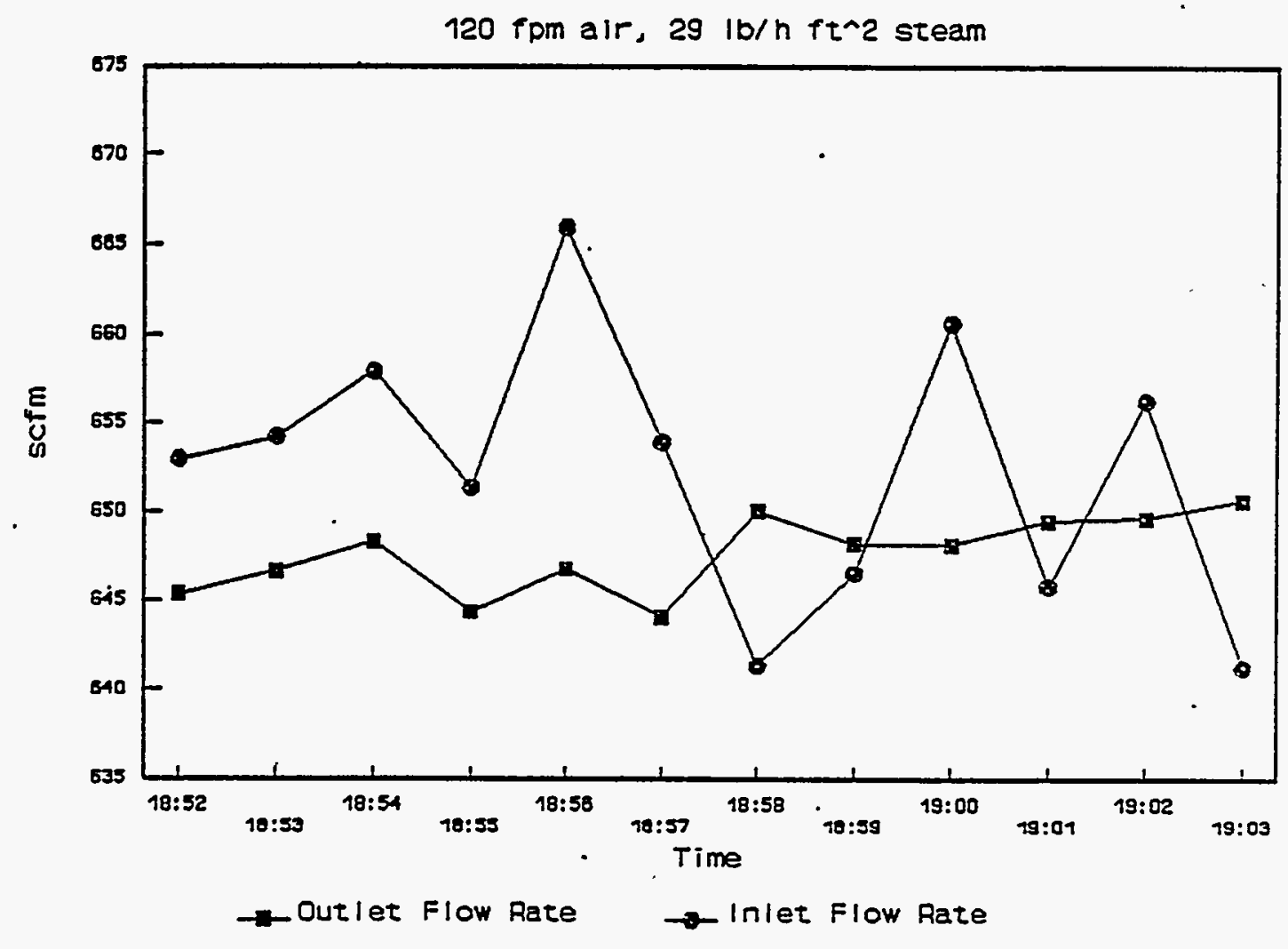

FIGURE A.16 Offgas Flowrates at the SBS Inlet and Outlet vs. Time. Average values over data collection period:

Inlet $652.3 \mathrm{scfm}$

Outlet $647.6 \mathrm{scfm}$ 


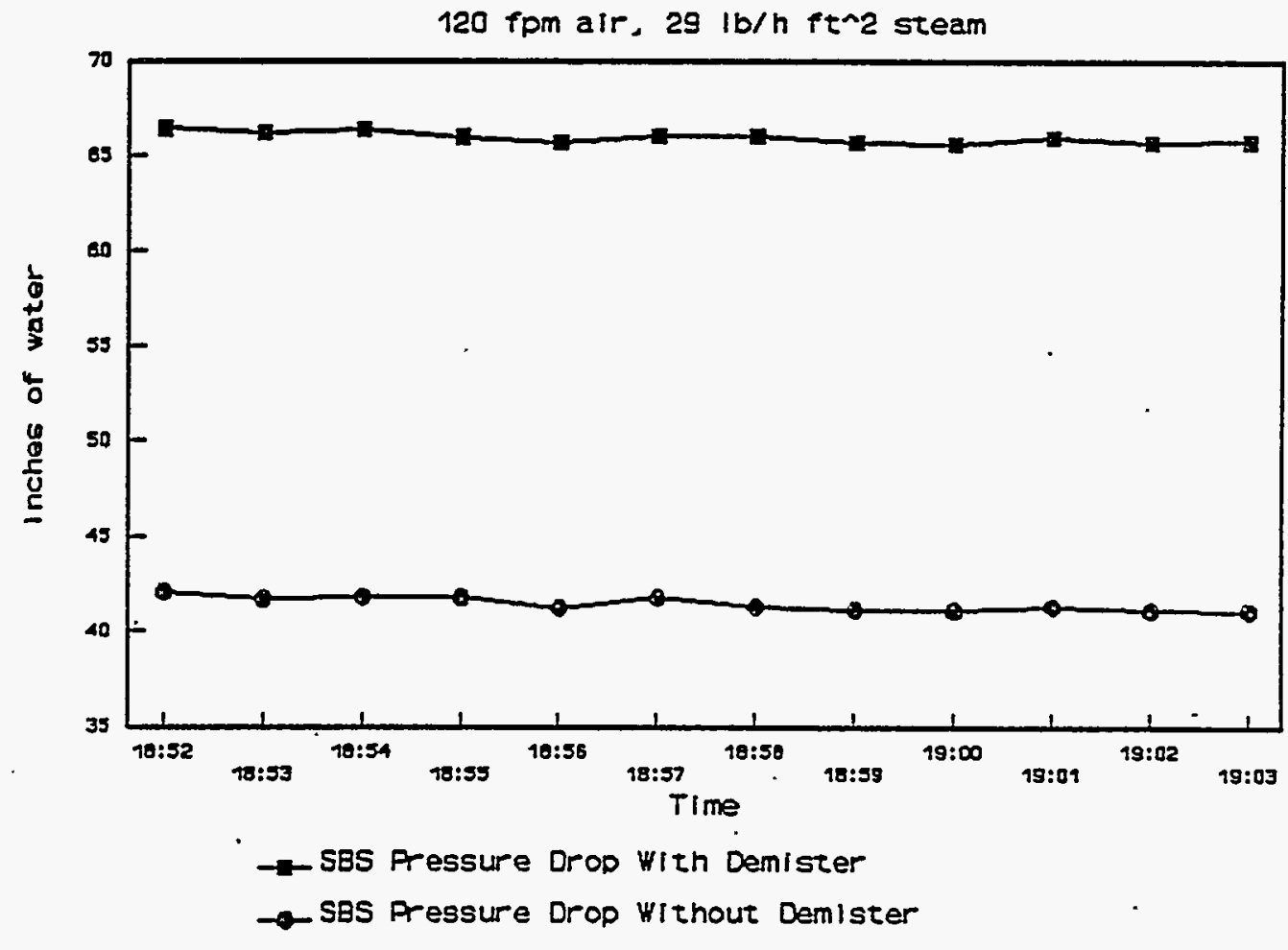

FIGURE A.17 SBS Pressure Drop vs. Time With and Without the Effect of the Chevron Demister. Average values: with demister 65.9 in. WC without demister 41.4 in. WC

A. 25 


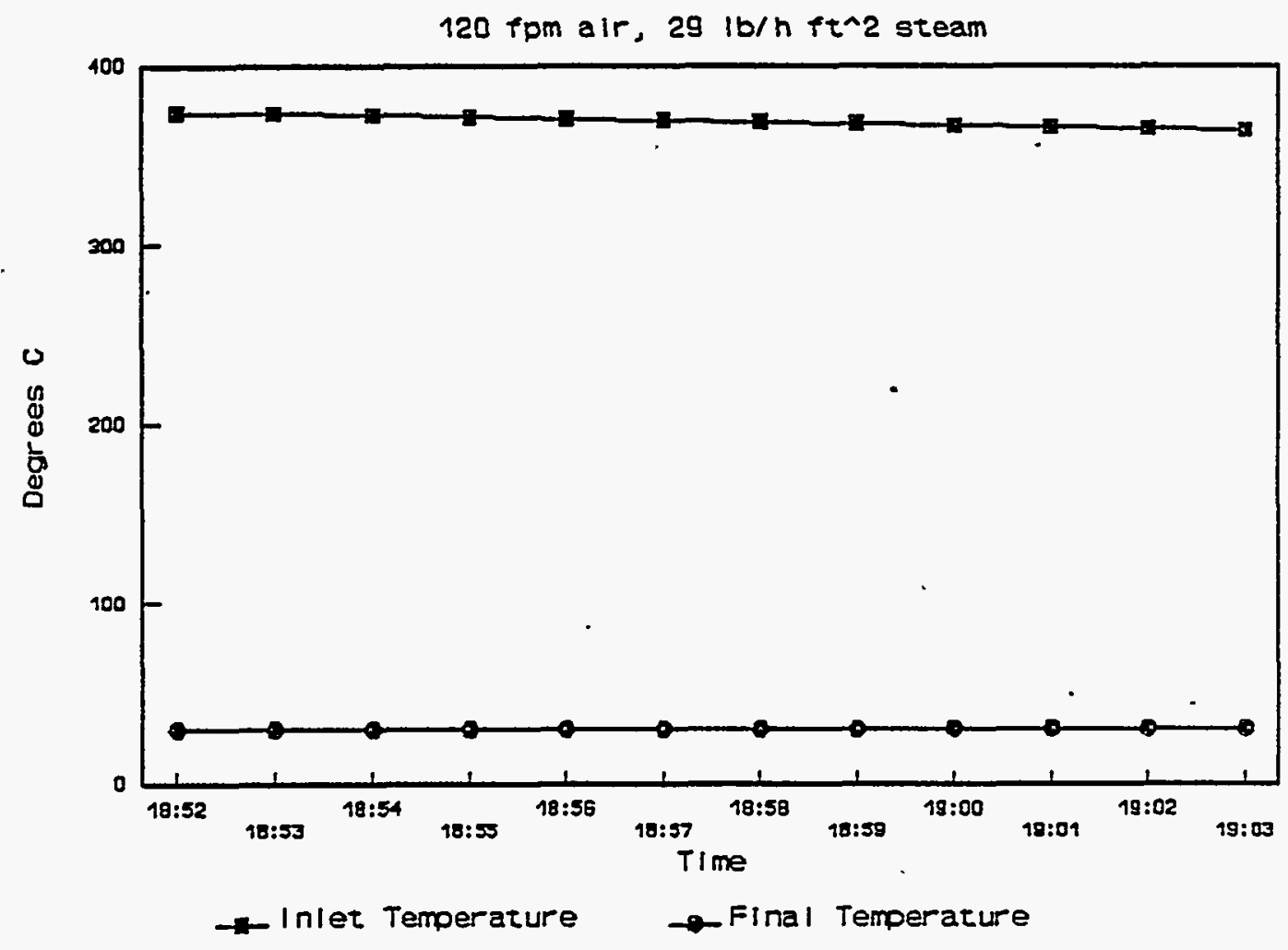

FIGURE A.18 Offgas Temperature as SBS Inlet and Outlet vs. Time. Average values over data

collection period:

Inlet $836.7^{\circ} \mathrm{C}$

Outlet $30.0^{\circ} \mathrm{C}$ 
Table A.7: $120 \mathrm{fpm}$ air, $201 \mathrm{lb} / \mathrm{h}$ Steam Surge, 6/25/92

\begin{tabular}{|c|c|c|c|c|}
\hline$\therefore$ & Target & Average & Begin ${ }^{1}$ & End ${ }^{1}$ \\
\hline $\begin{array}{l}\text { Air Superficial } \\
\text { Velocity }\end{array}$ & $120 \mathrm{fpm}$ & $111.7 \mathrm{fpm}$ & $120.7 \mathrm{fpm}$ & $104.5 \mathrm{fpm}$ \\
\hline Steam Flow Rate & $\begin{array}{c}201 \\
\mathrm{lb} / \mathrm{h} . \mathrm{ft} \mathrm{t}^{2}\end{array}$ & $\begin{array}{r}201.3 \\
1 \mathrm{~b} / \mathrm{h} . \mathrm{ft}^{2} \\
\end{array}$ & $\begin{array}{r}201.6 \\
\text { lb/h.ft }\end{array}$ & $\begin{array}{c}200.7 \\
\mathrm{lb} / \mathrm{h} . \mathrm{ft} \mathrm{t}^{2}\end{array}$ \\
\hline SBS_DP & $N / A$ & $64.3^{n} \mathrm{H}_{2} \mathrm{O}$ & $64.5 " \mathrm{H}_{2} \mathrm{O}$ & $64.5 " \mathrm{H}_{2} \mathrm{O}$ \\
\hline Corrected SBS $\mathrm{DP}^{3}$ & $\mathrm{~N} / \mathrm{A}$ & $44.7^{n} \mathrm{H}_{2} \mathrm{O}$ & $45.2 " \mathrm{H}_{2} \mathrm{O}$ & $44.4 " \mathrm{H}_{2} \mathrm{O}$ \\
\hline $\begin{array}{l}\text { Gas Inlet } \\
\text { Temperature }\end{array}$ & $\mathrm{N} / \mathrm{A}$ & $290.9^{\circ} \mathrm{C}$ & $288.4^{\circ} \mathrm{C}$ & $273.6^{\circ} \mathrm{C}$ \\
\hline $\begin{array}{l}\text { Gas Outlet } \\
\text { Temperature }\end{array}$ & $\mathrm{N} / \mathrm{A}$ & $49.1^{\circ} \mathrm{C}$ & $37.4^{\circ} \mathrm{C}$ & $58.0^{\circ} \mathrm{C}$ \\
\hline $\begin{array}{l}\text { SBS Average } \\
\text { Temperature }\end{array}$ & $N / A$ & $50.4^{\circ} \mathrm{C}$ & $37.5^{\circ} \mathrm{C}$ & $59.4^{\circ} \mathrm{C}$ \\
\hline
\end{tabular}

1. Averages for the first and last minute, respectively, of data collection.

2. Superficial air-only velocity in SBS bed evaluated at exit conditions (ACFM/Bed Area). The value reported represents an average of the estimates made based on the SBS entrance and exit flows.

3: Value of SBS DP with the chevron demister pressure drop subtracted.

4. An average of all 27 thermocouples, averaged over the duration of the data collection period. 


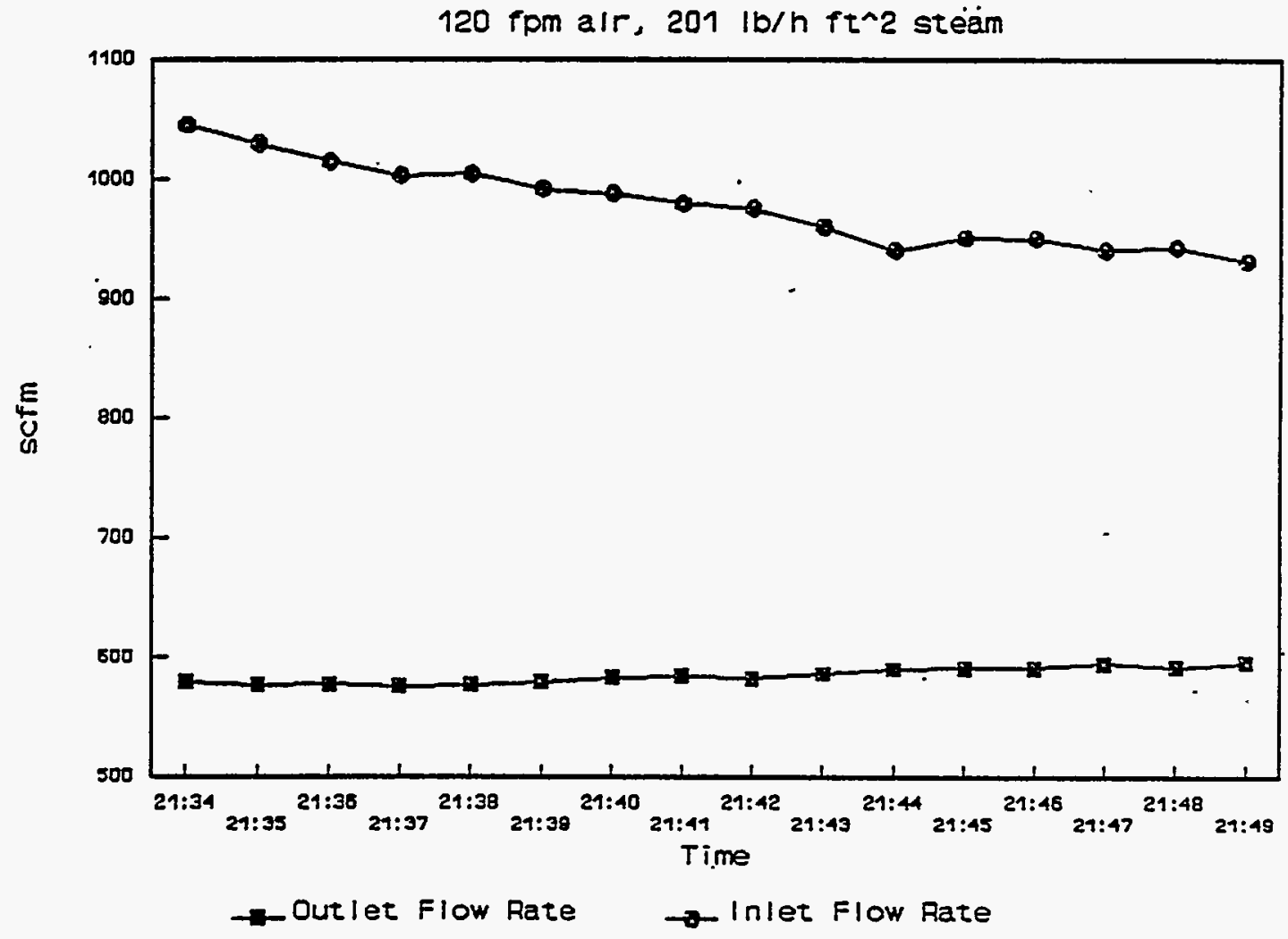

FIGURE A.19 Offgas Flowrates at the SBS Inlet and Outlet vs. Time. Average values over data collection period:

Inlet 977.5 scfm

Outlet $584.4 \mathrm{scfm}$. 


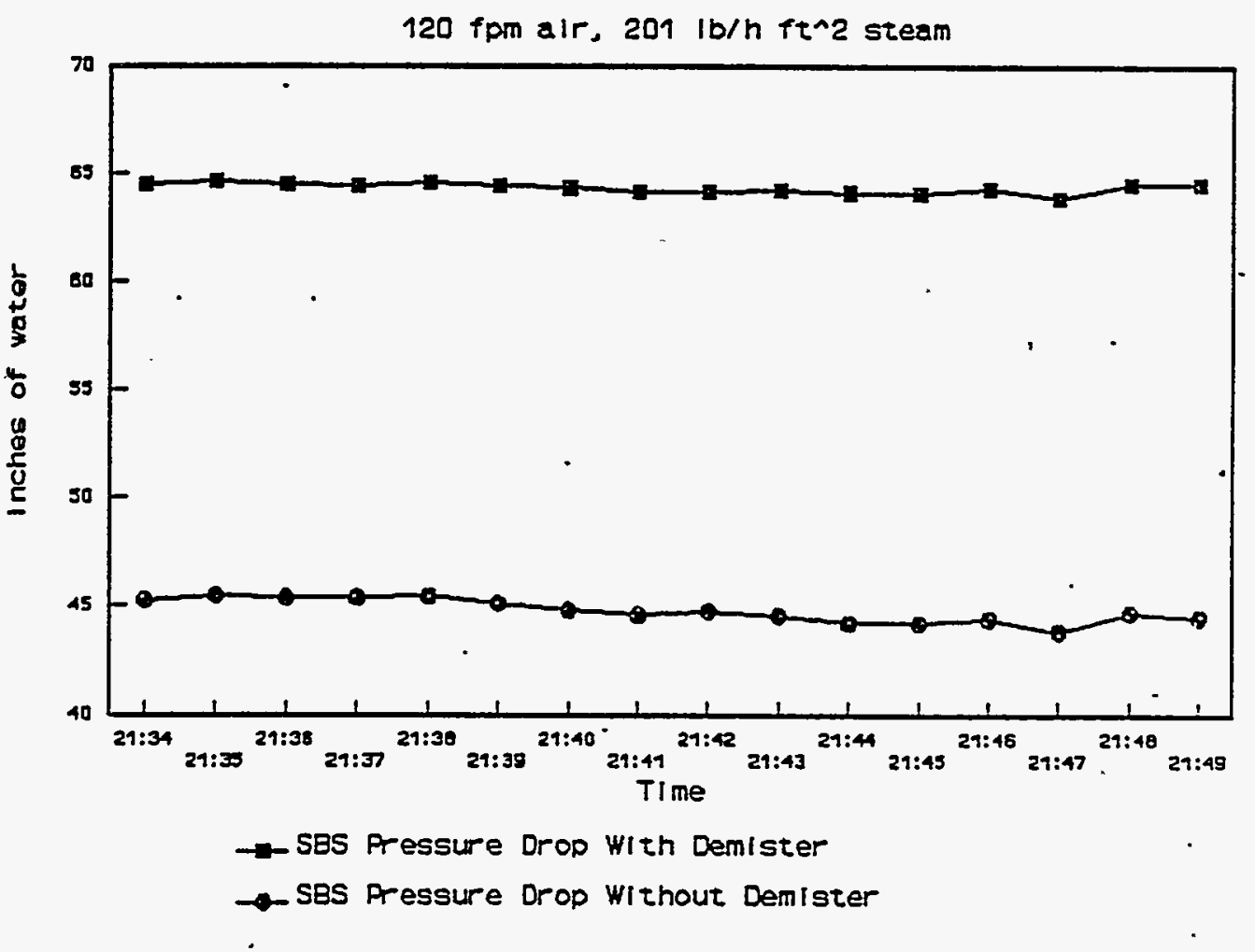

FIGURE A.20 SBS Pressure Drop vs. Time With and Without the Effect of the Chevron Demister. Average values: with demister 64.3 in. WC without demister 44.7 in. WC

A. 29 


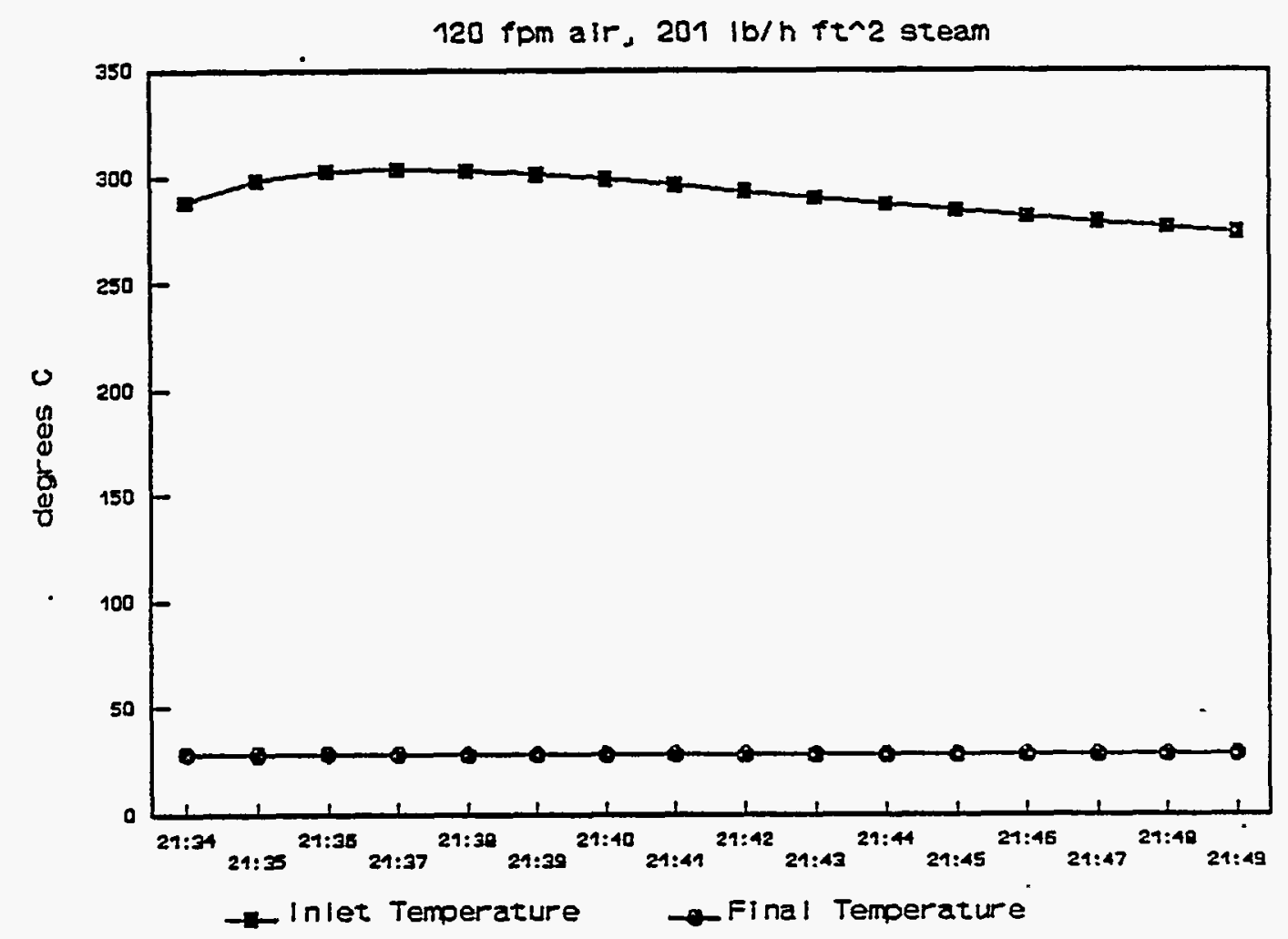

FIGURE A.21 Offgas Temperature at the SBS Inlet and Outlet vs. Time. Average values over data collection period:

Inlet $290.9^{\circ} \mathrm{C}$

Outlet $28.1^{\circ} \mathrm{C}$

A. 30 
Table A.8: Maximum Air Flow, No Steam, 6/25/92

\begin{tabular}{||l|c|c|c|c|}
\hline & Target & Average & Min $^{1}$ & Max $^{1}$ \\
\hline $\begin{array}{l}\text { Air Superficial } \\
\text { Velocity }\end{array}$ & $180 \mathrm{fpm}$ & $148.8 \mathrm{fpm}$ & - & - \\
\hline Steam Flow Rate & 0 & 0 & - & - \\
\hline SBS DP & $\mathrm{N} / \mathrm{A}$ & $78.5^{\prime \prime} \mathrm{H}_{2} \mathrm{O}$ & $76.2^{\prime \prime} \mathrm{H}_{2} \mathrm{O}$ & $81.0^{\prime \prime} \mathrm{H}_{2} \mathrm{O}$ \\
\hline Corrected SBS DP & $\mathrm{N} / \mathrm{A}$ & $42.4^{\prime \prime} \mathrm{H}_{2} \mathrm{O}$ & - & - \\
\hline $\begin{array}{l}\text { Gas Inlet } \\
\text { Temperature }\end{array}$ & $\mathrm{N} / \mathrm{A}$ & $204.9^{\circ} \mathrm{C}$ & - & - \\
\hline $\begin{array}{l}\text { Gas Outlet } \\
\text { Temperature }\end{array}$ & $\mathrm{N} / \mathrm{A}$ & $50.3^{\circ} \mathrm{C}$ & - & - \\
\hline $\begin{array}{l}\text { SBS Average } \\
\text { Temperature }\end{array}$ & $51.7^{\circ} \mathrm{C}$ & $51.3^{\circ} \mathrm{C}$ & - & - \\
\hline
\end{tabular}

1. Minima and maxima over 1 minute intervals were averaged during the data collection period.

2. Superficial air-only velocity in SBS bed evaluated at exit conditions (ACFM/Bed Area). The value reported represents an average of the estimates made based on the SBS entrance and exit flows.

3. Value of SBS DP with the chevron demister pressure drop subtracted.

4. An average of all 27 thermocouples, averaged over the duration of the data collection period.

5. - No data available. 


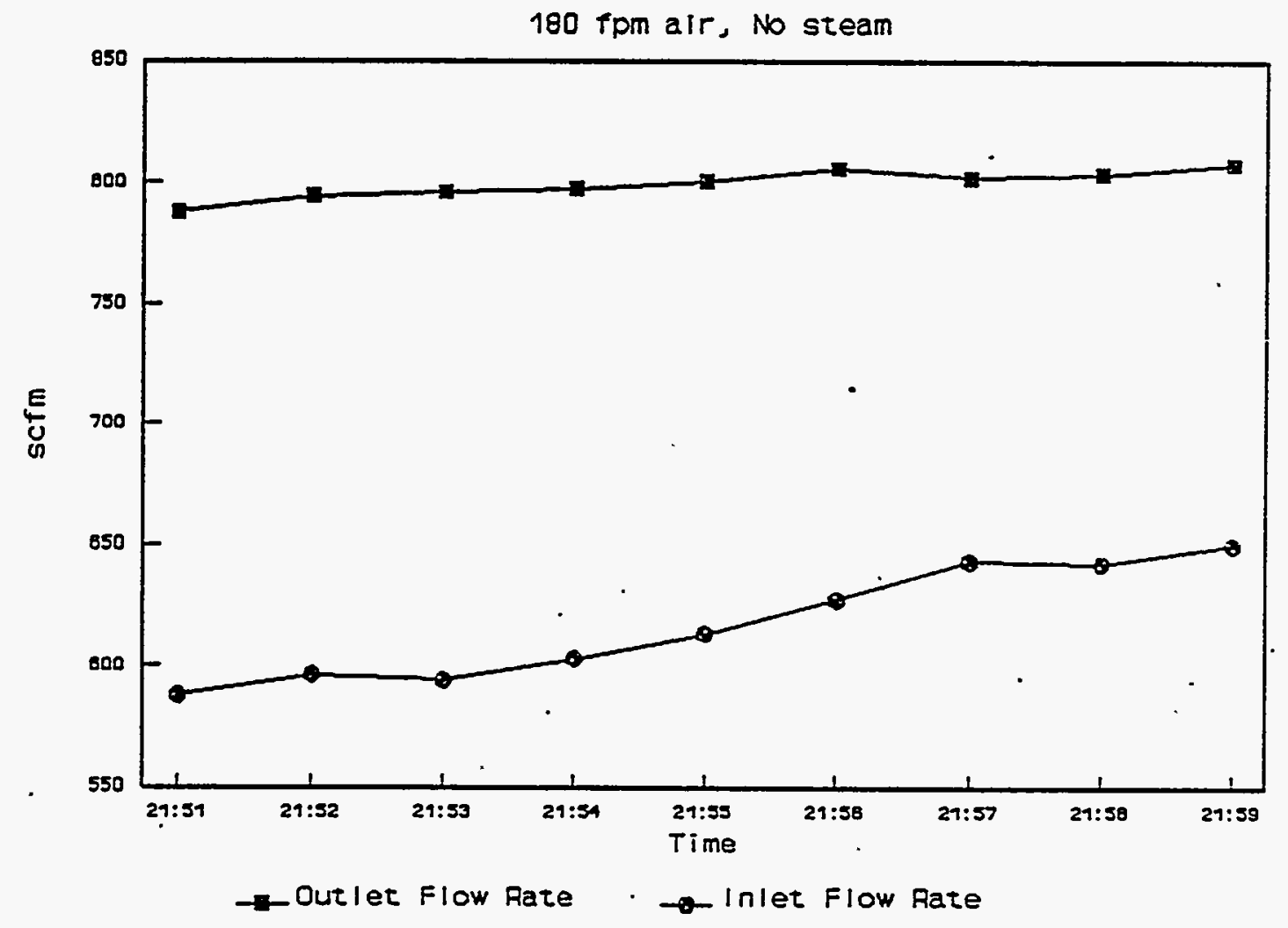

Figure A.22 Offgas F.lowrates at SBS Inlet and Outlet vs. Time. Average values over data collection period: Inlet $977.5 \mathrm{scfm}$ Outlet 584.4 scfm

A. 32 


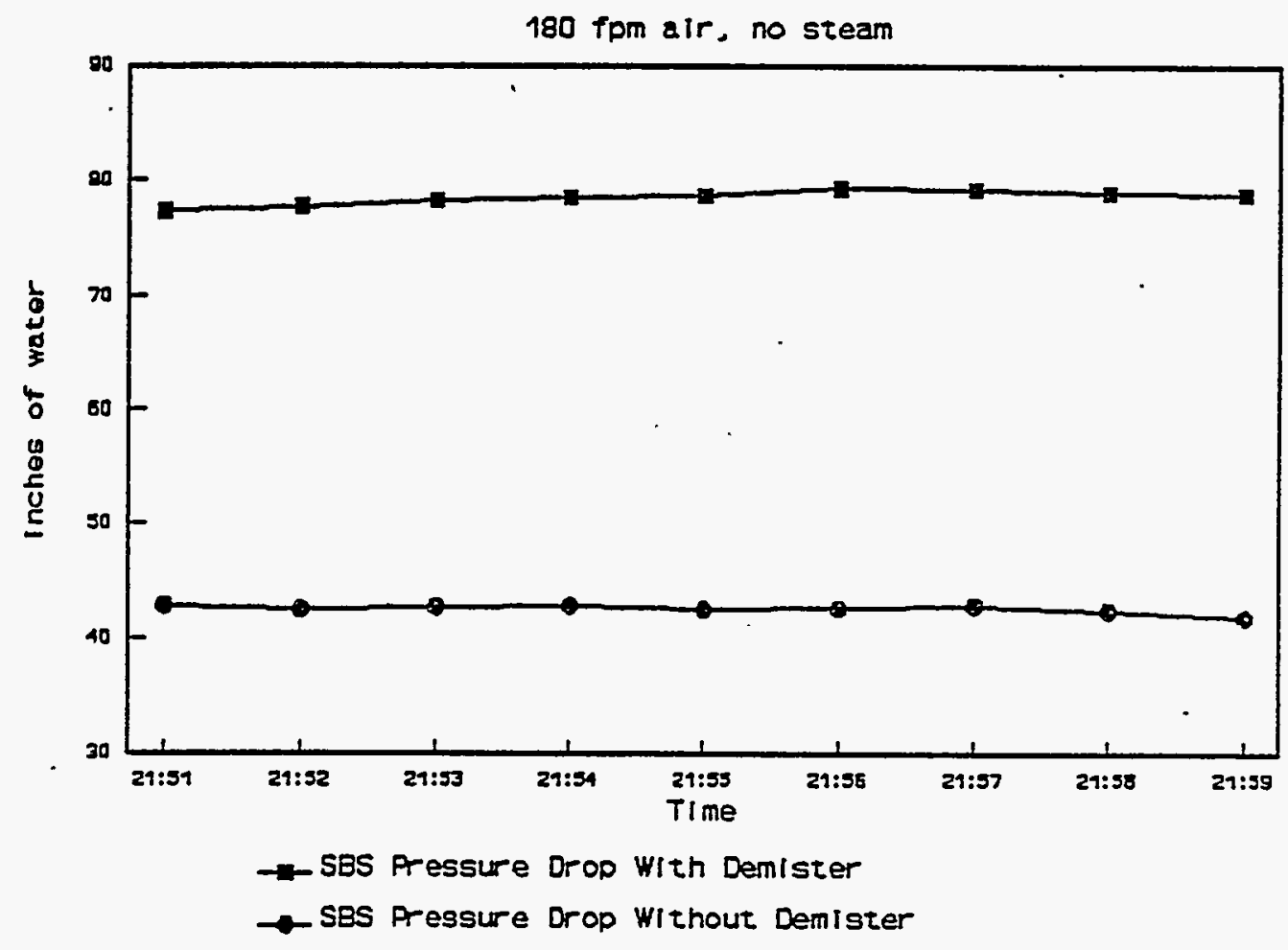

Figure A.23 SBS Pressure Drop vs. Time With and Without the Effect of the Chevron Demister. Average values: with demister 78.5 in. WC without demister 42.4 in. WC

\section{A. 33}




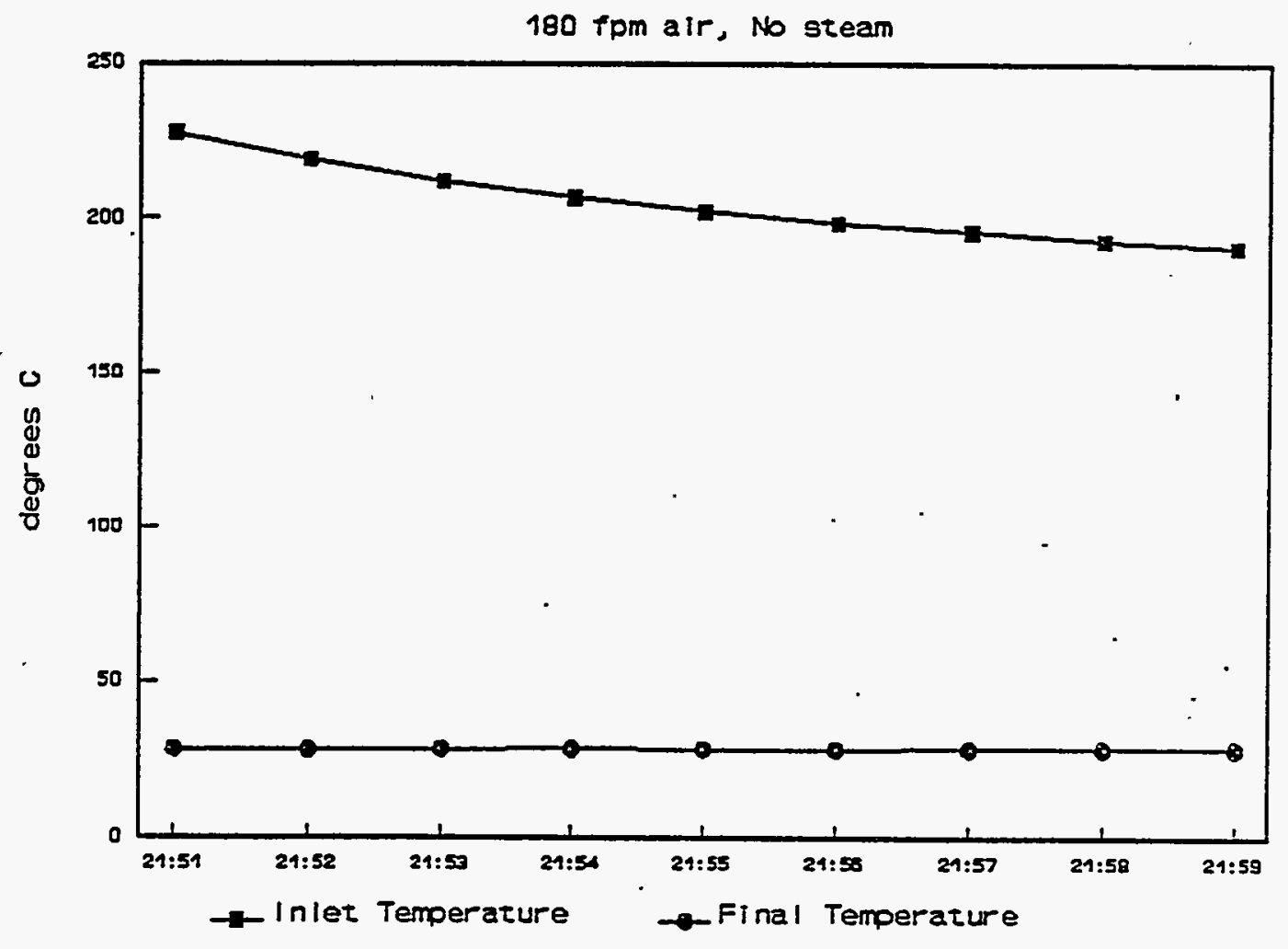

Figure A.24 Offgas Temperature at SBS Inlet and Outlet vs. Time. Average values over data collection period:

Inlet $290.8^{\circ} \mathrm{C}$

Outlet $28.1^{\circ} \mathrm{C}$

\section{A. 34}


Table A.9:

Maximum Air Flow, No Steam, Offgas Line Disconnected $7 / 30 / 92$

\begin{tabular}{||l|c|c|c|c||}
\hline & Target & Average & Min $^{1}$ & Max $^{1}$ \\
\hline $\begin{array}{l}\text { Air Superficial } \\
\text { Velocity }\end{array}$ & $180 \mathrm{fpm}$ & $178.1 \mathrm{fpm}$ & $-{ }^{6}$ & - \\
\hline Steam Flow Rate & 0 & 0 & - & - \\
\hline SBS DP & $\mathrm{N} / \mathrm{A}$ & $53.8^{\prime} \mathrm{H}_{2} \mathrm{O}$ & $49.6^{\prime \prime} \mathrm{H}_{2} \mathrm{O}$ & $57.6^{\prime \prime} \mathrm{H}_{2} \mathrm{O}$ \\
\hline Corrected SBS $\mathrm{DP}^{4}$ & $\mathrm{~N} / \mathrm{A}$ & $50.2^{\prime \prime} \mathrm{H}_{2} \mathrm{O}$ & - & - \\
\hline $\begin{array}{l}\text { Gas Inlet. } \\
\text { Temperature }\end{array}$ & $\mathrm{N} / \mathrm{A}$ & $032.2^{\circ} \mathrm{C}$ & - & - \\
\hline $\begin{array}{l}\text { Gas Outlet } \\
\text { Temperature }\end{array}$ & $\mathrm{N} / \mathrm{A}$ & $20.3^{\circ} \mathrm{C}$ & - & - \\
\hline $\begin{array}{l}\text { SBS Average } \\
\text { Temperature }\end{array}$ & $\mathrm{N} / \mathrm{A}$ & $20.6^{\circ} \mathrm{C}$ & - & - \\
\hline
\end{tabular}

1. Minima and maxima over 1 minute intervals were averaged during the data collection period.

2. Superficial air-only velocity in SBS bed evaluated at exit conditions (ACFM/Bed Area). The value reported represents an average of the estimates made based on the SBS entrance and exit flows.

3. SBS pressure drop measured from the room air to the SBS plenum space. Does not include the demister pressure- drop.

4. Value of SBS DP with entrance effect for disconnected offgas line the subtracted.

5. An average of all 27 thermocouples, averaged over the duration of the data collection period.

.6. - No data available. 


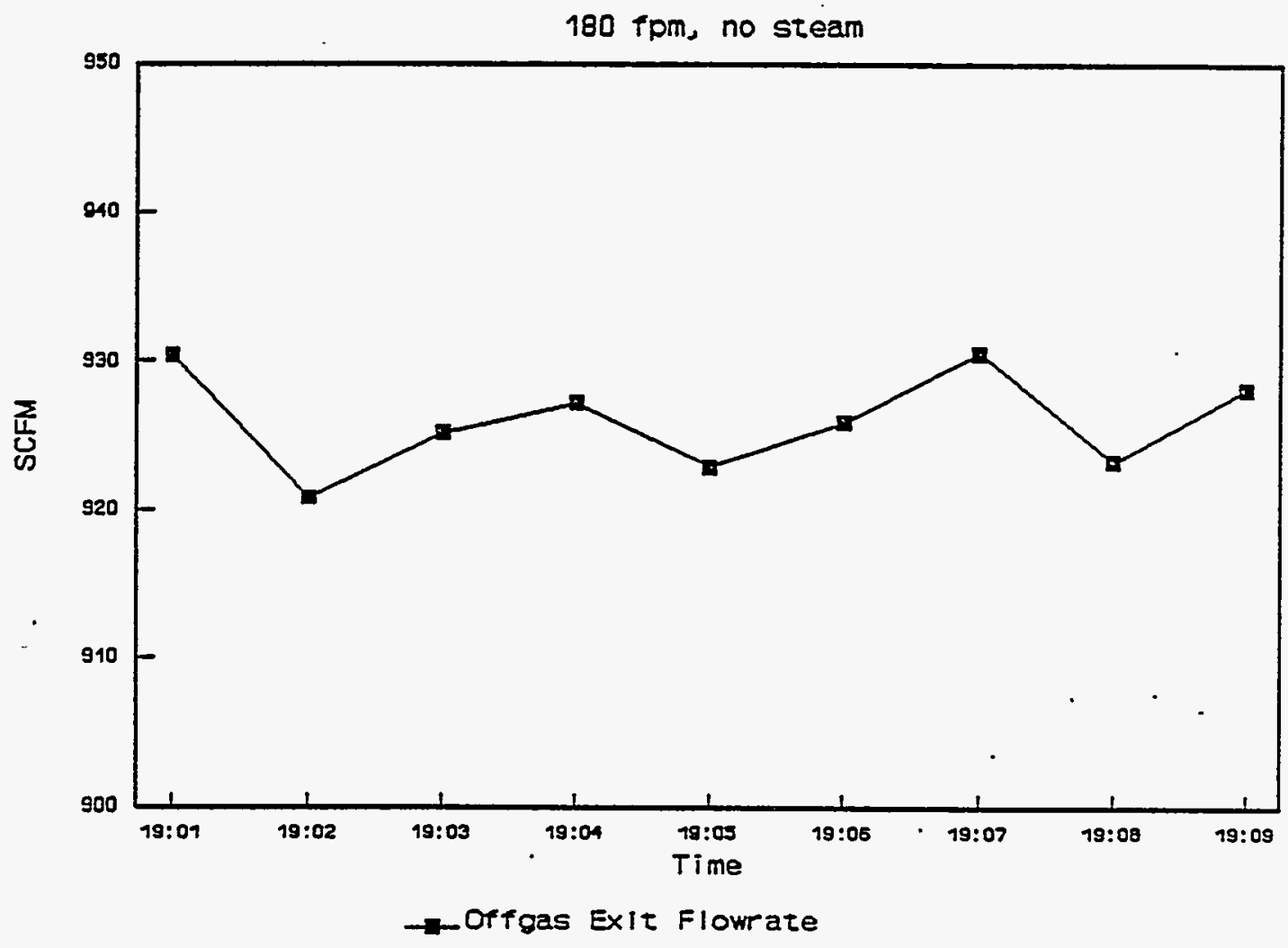

Figure A.25 Offgas Flowrate at SBS Outlet vs. Time. Average values over data collection $926 \mathrm{scfm}$.

A. 36 


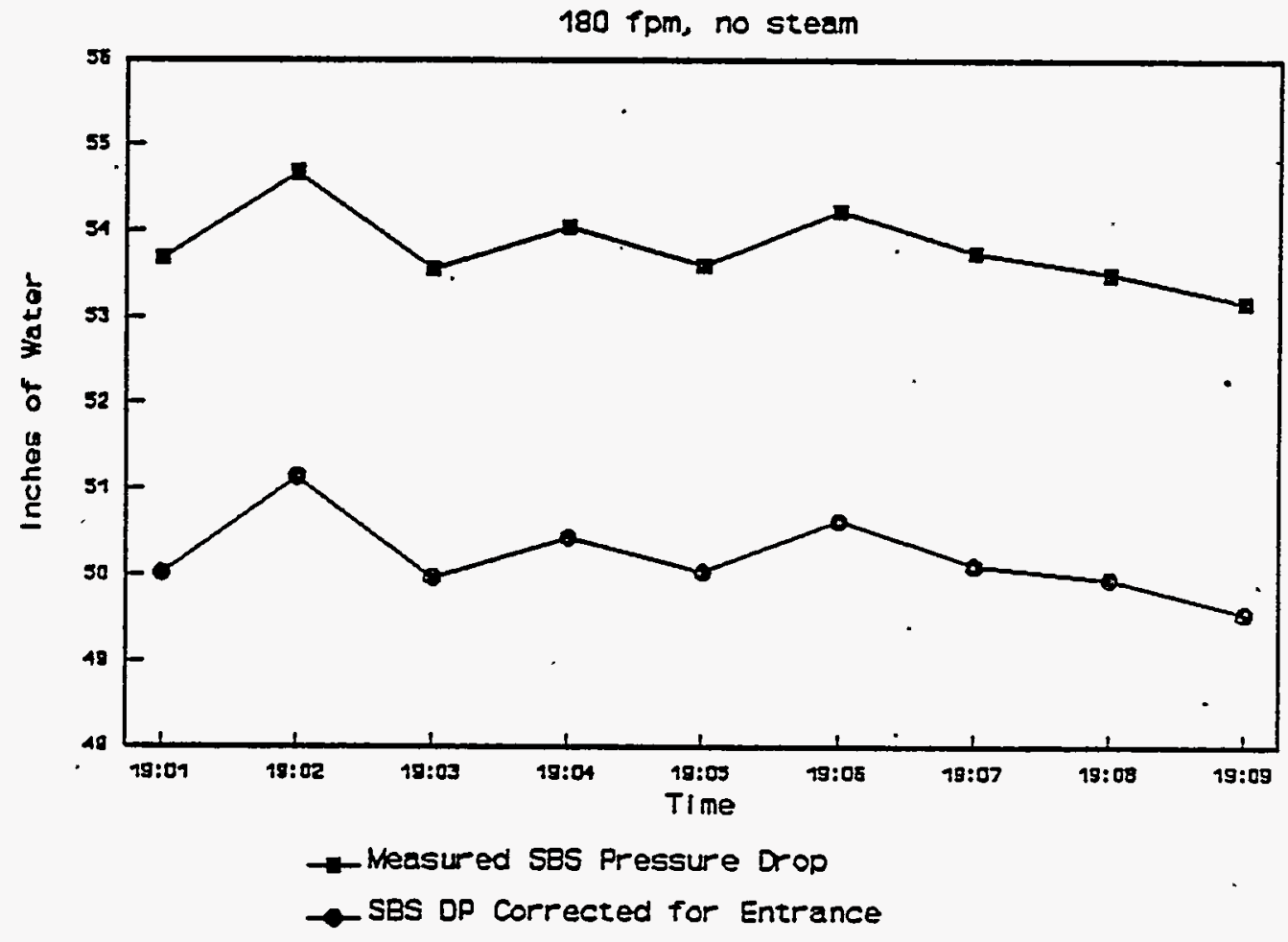

Figure A.26 SBS Pressure Drop vs. Time With and Without Entrance Correction for Disconnected offgas Iine. Pressure drop measurement did not include the chevron demister. Average values: measured 53.8 in. WC with entrance correction 50.2 in. WC

A. 37 


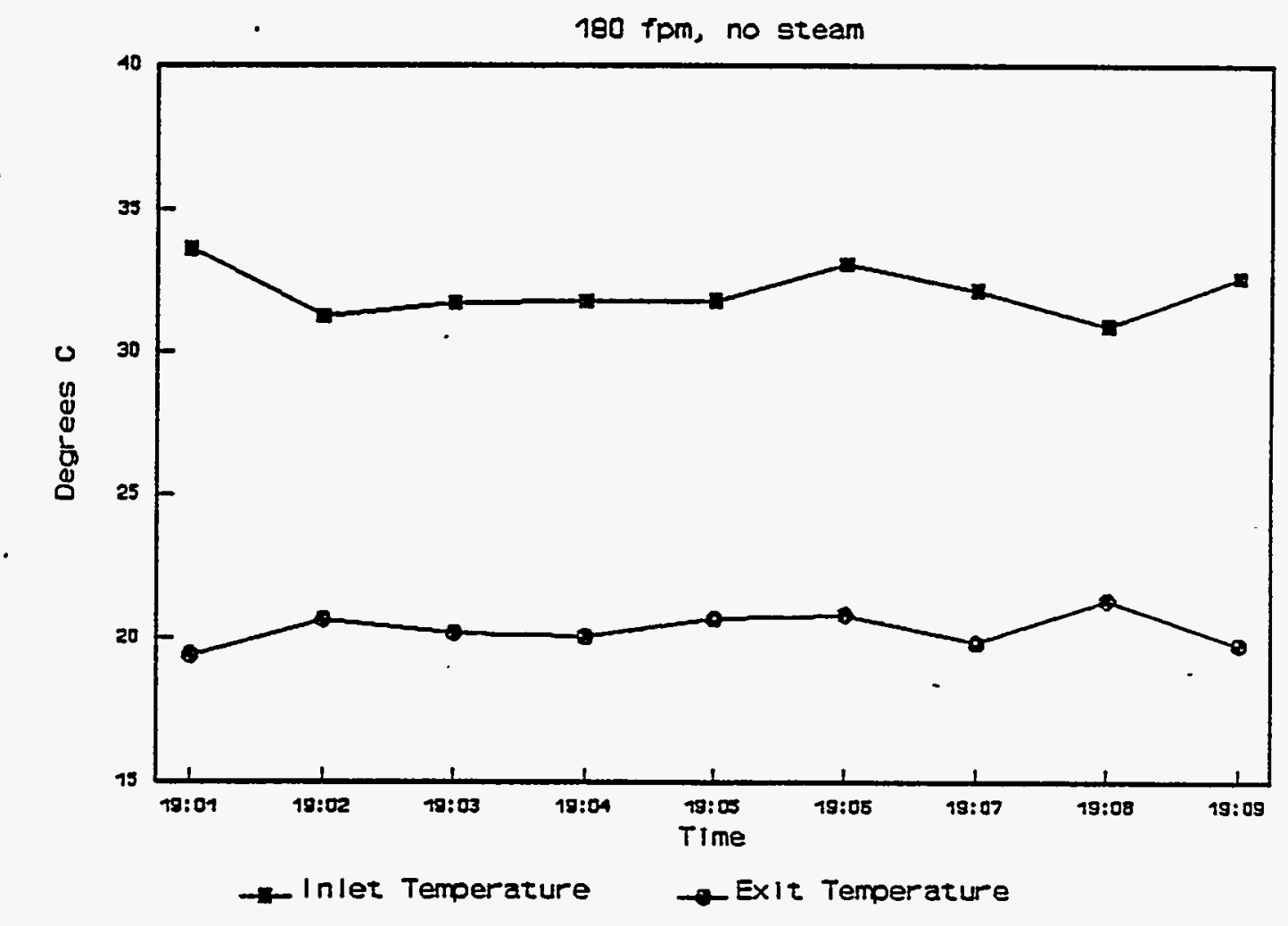

Figure A.27 Offgas Temperature at SBS Inlet and Outlet vs. Time. Air is drawn from room air.

Average values over data collection period: Inlet $32.2{ }^{\circ} \mathrm{C}$

Outlet $20.3{ }^{\circ} \mathrm{C}$ 
APPENDIX B: FLUOR DATA NEED SHEETS 


\section{FLUOR DANIEL TECHNOLOGY NEED DATA SHEET}

Tech Need Item 3.1a - Film Cooler Pressure Drop Data

- In the absence of experimental data, the pressure drop across the film cooler used for Preliminary Design calculations is estimated based on the total flow of melter off-gas and film cooler air through an assumed length of straight pipe. Air addition through slots along the film cooler and deposit formation increase turbulence in the film cooler. Therefore, the pressure drop may possible be above that estimated for Preliminary Design calculations. In addition, the film cooler air is added along the length of the film cooler, rather than at the inlet. The overall effect of these two competing factors on the film cooler pressure drop must be determined experimentally.

The pressure drop across the film cooler is required to determine the following:

- Submergence of the MOG SBS inlet. for the canister pour spout vent.

- Submergence of the PVV SBS inlet for the melter off-gas from the back-up film cooler.

- Accurate sizing of the MOG exhauster.

In addition, the film cooler pressure data are needed to verify the results of the upcoming MOG System dynamic simulation.

Fluor Daniel has been informed that the pilot scale film cooler is not prototypic of the DWPF film cooler as will be used at the IIWV. The pressure drop across the film cooler may not be a significant part of the total pressure drop across the film cooler and off-gas line. Therefore, the pressure drop across both the film cooler and the combined film cooler and off-gas line must be measured. The film cooler in the Pilot Scale Ceramic Melter must be tested at the conditions shown on the following page. 
[ech Need Item 3.1a - Data Sheet for Film Cooler Pressure Drop

\begin{tabular}{|c|c|c|c|c|c|c|c|}
\hline $\begin{array}{l}\text { Melter Air } \\
\text { Flow ACFM }\end{array}$ & $\begin{array}{c}\text { Plenum Temip } \\
\text { deg } f\end{array}$ & $\begin{array}{c}\text { Plenum } \\
\text { Pressure psia }\end{array}$ & $\begin{array}{l}\text { Film Cooler } \\
\text { Air Flow } \\
\text { Ib/hr }\end{array}$ & $\begin{array}{c}\text { Outlet Temp } \\
\text { deg F }\end{array}$ & $\begin{array}{l}\text { Film Cooler } \\
\text { Pressure Drop } \\
\text { inches HC } \\
\text {. }\end{array}$ & $\begin{array}{l}\text { Film Cooler/ } \\
\text { Off-Gas Line } \\
\text { Pressure Drop } \\
\text { inches HC }\end{array}$ & Case \\
\hline & & & & & & & Normal \\
\hline * & & & & & $\cdot$ & & Surge \\
\hline$:$ & 1450 & & $* *$ & & & & $\begin{array}{l}\text { Max Plenum } \\
\text { Temp }\end{array}$ \\
\hline
\end{tabular}

* 3 time normal noncondensible flow and 7 times normal steam flow.

$\star \star 1.16$ times normal air flow. 
Tech Need Item 3.1a - Data Sheet for Film Cooler Pressure Drop

\begin{tabular}{|c|c|c|c|c|c|c|c|}
\hline $\begin{array}{l}\text { Melter Air } \\
\text { Flow ACFM } \\
\end{array}$ & $\begin{array}{l}\text { Plenum } \\
\text { Temp of } \\
\end{array}$ & $\begin{array}{l}\text { Plenum } \\
\text { Pressure psia } \\
\end{array}$ & $\begin{array}{c}\text { Film Cooler } \\
\text { Air Flow } \\
\text { lb/hr } \\
\end{array}$ & $\begin{array}{c}\text { SBS Inlet } \\
\text { Temp of } \\
\end{array}$ & $\begin{array}{l}\text { Film Cooler } \\
\text { Pressure Drop } \\
\text { inches WC } \\
\end{array}$ & $\begin{array}{c}\text { Film Cooler/ } \\
\text { Off-Gas Line } \\
\text { Pressure Drop } \\
\text { inches WC } \\
\end{array}$ & Case \\
\hline$A$ & C & D & $E$ & & & & Normal \\
\hline B & C & D & $E$ & & & & Surge \\
\hline$A$ & 1450 & D & $F$ & & & & $\begin{array}{c}\text { Max Plenum } \\
\text { Temp }\end{array}$ \\
\hline
\end{tabular}

A) Air flowrate to be delivered to the melter will be provided by Pat Early at Fluor. The steam flowrate will be selected to produce the same linear velocity within the film cooler as in HWVP. The ID of HWVP film cooler will be provided by Pat Early at Fluor.

B) Intended to be a $3 X$ non-condensible surge and $7 X$ steam surge. The $7 X$ will be applied to the steam rate in (A). The $3 X$ will be applied to the non-condensible flow and should be negligible.

C) A nominal plenum temperature will be specified by Pat Early at Fluor.

D) Plenum pressure target will be -7" WC. Barometric pressure will be recorded for the day of testing.

E) The film cooler flow rate will be scaled based film cooler cross-sectional area from HWVP flow. The inside diameter of llWVP film cooler will be provided by Pat Early at Fluor.

F) Air flowrate to the film cooler will be adjusted to 1.16 times the flowrate specified in (E). 


\section{FLUOR DANIEL TECHNOLOGY NEED DATA SHEET}

Tech Néed Item $3.2 a$ - SBS Packina Selection

The design of the HWVP Submerged Bed Scrubber (SBS) developed in Prel iminary Design is based on PNL report "Design Procedure for Sizing a Submerged Bed Scrubber for Nirborne Particulate Removal", PNL-6036/UC-70 dated April 1987. The report recommends the use of $3 / 8$ in ceramic balls as the bed packing material, which is the current HWVP design.

A subsèquent PNL report "Submerged Bed Scrubber Evaluation", HWVP-89-IVJ0020500A dated July 1989 reviews the available data from the PNL Pilot Scale Ceramic Melter (PSCM) SBS, the PNL Submerged Gravel Scrubber (SGS), the Hest Valley Demonstration Project (WVDP), and Power Reactor and Nuclear Fuel Development Corporation (PNC) of Japan. The subsequent report recommends testing Intalox saddles and wire mesh screen as the SBS packing material. The saddles and screen packings have higher vold fractions and surface areas, which increase the maximum superficial gas velocity without promoting gas channeling or reducing removal efficiency. Iligher superficial velocities could reduce the size of the packed bed and congestion in the cell.

Fluor Danjel will incorporate saddle packing into the SBS design only if the test resul.ts are received in time to support the Detailed Design package schedule. Testing must also prove that the saddles have significant. advantages over balls. To facilitate Fluor Daniel in incorporating the saddles, tests should provide the data shown on the attached data sheet. The physical details of the scrubber ani the cooling colls should also be. provided, as well as the coil cooling water flow rate and inlet and outlet temperatures. 


\section{ELUOR DANIEL TECHNOLOGY NEED DATA SHEET}

Tech Need Items 3.2b and 3.2c - Pressure Drop Data for SBS Distribution Plate and Packing

The pressure drop across the packing and distribution plate during normal operation is required to determine the submergence of the SBS inlet for the canister pour spout vent. The pressure drop is also required for accurate sizing of the MOG exhauster.

A PNL report "Submerged Bed Scrubber Evaluation", HWVP-89-IVJ0020500A dated July 1989 recomends testing packings other than the previously tested balls. (See Item No. 3.2a) It also recommends testing another distribution plate. design. (See Item No. 3.2e) The pressure drop across the packings and distribution plate must be determined experimentally as part of the test programs in Item Nos. 3.2a and 3.2e. The results of the testing with the new packing and the distribution plate design are to be reported on the data sheet with Item 3.2a. The individual pressure drops for the packing and

distribution need not be reported separately. The combined pressure drop for the packing and distribution plate is adequate. 


\section{FLUOR DANIEL TECHNOLOGY NEED DATA SHEET}

Tech Need Item $3.2 d$ - SBS Sparge Ring Testing

In the absence of experimental data, the SBS liquid sparger design developed in Prel iminary Design was based on an assumed sparger flow rate, velocity, and hole size. A PNL report "Submerged Bed Scrubber Evaluation"; HWVP-89-

IVJ0020500A dated July 1989 reviews the design of an air sparger, rather than liquid sparger, used in the Hest Valley Demonstration Project (WVDP).

The design of the HWVP 1 iquid sparger developed in Preliminary Design must be tested. The sparger is tested by entraining a known quantity of solids placed on the bottom of the PSCM SBS. The solids used in the testing should be the same size or larger than those expected to be collected in the actual HWVP SBS. The liquid is removed from the SBS and the entrained sol ids are then collected and measured.

The flow rate to the HWVP sparger developed in Preliminary Design is $25 \mathrm{gpm}$. However, $25 \mathrm{gpm}$ is not adequate to maintain the scrub tank level when the scrub tank is being jetted out for solids removal. Solids removal from the scrub tank is currently planned for normal operation when the off-gas flows to the MOG System. Allowing the level to drop would interfere with the melter pressure control. As a result, the flow rate should be increased to $50 \mathrm{gpm}$. The holes should be sized for a pressure drop of roughly 10 psi.

If the design does not successfully remove deposited solids, alternative sparger designs, including an eductor, should be tested. Up to $50 \mathrm{gpm}$ of

- motive fluid at up to 45 PSIG is available for the eductor. If necessary, a plexiglass model of the SBS can be built for observation of sparger performance. 


\section{FLUOR DANIEL TECHNOLOGY NEED DATA SHEET}

Tech Need Item $3.2 e$ - SBS Distribution Plate and Liquid Risers

The design of the HWVP Submerged Bed Scrubber (SBS) is based on PNL report "Design Procedure for Sizing a Submerged Bed Scrubber 1987. The distribution plate design developed in Preliminary Design is based on the hotd size and spacing recommended in the report.

A subsequent PNL report "Submerged Bed Scrubber Evaluation", HWYP-89-IVJ0020500A dated July 1989 reviews the available data from the PNL Pilot Scale Ceramic Melter (PSCM) SBS, the PNL Submerged Gravel Scrubber (SGS), the Hest Valley Demonstration Project (WVDP), and Power Reactor and Nuclear Fuel Development Corporation (PNC) of Japan. The report expresses concern that liquid flow into the packed bed is not adequately addressed. The report also provides a distribution plate design that is commonly used in counter-current gas/liquid flows. Since the distribution plate design is not yet demonstrated with the co-current flow present in this application, testing of the design is recommended.

The design of the distribution plate for co-current gas and liquid flow must be supported with additional testing. If uniform distribution of the gas is not achieved at the bottom of the bed, insufficient SBS bed height prevents gas redistribution as the gas flows up through the bed.

The recommended distribution plate design must be built and tested in the PSCN SBS in conjunction with the bed packing testing discussed with Item No. 3.2a. The test apparatus must include provisions to measure the bed radial. temperatures. At a minimum, the bed temperatures near the inlet pipe, near the outside of the bed, and midway between the inlet pipe and the outside of the bed should be measured. The results are reported on the data sheet with I tem 3.2a. 


\section{FLUOR DANIEL TECHNOLOGY NEED DATA SHEET}

ach Need Item Nos, 3.2a, 3,2b, 3,2c, and 3,2e - Data Sheet for MOG SBS Testing \& inch Ceramic Intalox Saddles

\begin{tabular}{|c|c|c|c|c|c|c|c|c|c|c|c|c|}
\hline $\begin{array}{c}\text { Air } \\
\text { Superficial } \\
\text { Velocity* } \\
\text { fpm } \\
\end{array}$ & $\begin{array}{l}\text { Steam Flow } \\
\text { lb/hr-ft? }\end{array}$ & $\begin{array}{l}\text { Press } \\
\text { Drop } \\
\text { "WC" }\end{array}$ & $\begin{array}{l}\text { DF } \\
\text { Under } \\
1 \\
\text { Micron }\end{array}$ & $\begin{array}{c}\text { DF } \\
\text { Over } \\
1 \\
\text { Micron } \\
\end{array}$ & $\begin{array}{l}\text { Gas } \\
\text { Inlet } \\
\text { Temp } \\
\text { deg F }\end{array}$ & $\begin{array}{c}\text { Gas } \\
\text { Outlet } \\
\text { Temp } \\
\text { deg F } \\
\end{array}$ & $\begin{array}{c}\text { Lower } \\
\text { Bed } \\
\text { Temp } \\
\operatorname{deg} F \\
\end{array}$ & $\begin{array}{c}\text { Upper } \\
\text { Bed } \\
\text { Temp } \\
\text { deg F } \\
\end{array}$ & $\begin{array}{c}\text { Inner } \\
\text { Radial } \\
\text { Temp } \\
\text { deg F } \\
\end{array}$ & $\begin{array}{c}\text { Middle } \\
\text { Radial } \\
\text { Temp } \\
\text { deg F } \\
\end{array}$ & $\begin{array}{c}\text { Outer } \\
\text { Radial } \\
\text { Temp } \\
\text { deg } F \\
\end{array}$ & Case \\
\hline 60 & 35 & & & & & & & & & & & Normal \\
\hline 62 & 245 & & & & & & & & & & & Surge \\
\hline 120 & 35 & & & & & & & & & & & Normal \\
\hline 123 & 245 & & . & & & & & & & & & Surge \\
\hline 180 & 35 & & & & & & - & & & & & Normal \\
\hline 185 & 245 & & & & & & & & & & & Surge \\
\hline
\end{tabular}

* Please provide the minimum and maximum recommended superficial velocity. 
Fluor Daniel Technology Need Data Sheet (Revised)

Tech Need Item Nos. 3.2a, 3.2b, 3.2c, and 3.2e - Data Sheet for MOG SBS Testing $1 / 2$ inch Ceramic Intalox Saddles

\begin{tabular}{|c|c|c|c|c|c|c|c|c|}
\hline $\begin{array}{c}\text { Air } \\
\text { Superficial } \\
\text { Velocity* } \\
\text { fpm (A) }\end{array}$ & $\begin{array}{l}\text { Steam Flow } \\
\text { lb/hr-ft }\end{array}$ & $\begin{array}{l}\text { SBS } \\
\text { Press } \\
\text { Drop } \\
\text { "WC" }\end{array}$ & $\begin{array}{c}\text { DF } \\
\text { Under } \\
1 \\
\text { Micron }\end{array}$ & $\begin{array}{c}\text { DF } \\
\text { Over } \\
1 \\
\text { Micron }\end{array}$ & $\begin{array}{l}\text { Gas } \\
\text { Inlet } \\
\text { Temp } \\
0 F\end{array}$ & $\begin{array}{c}\text { Gas } \\
\text { Outlet } \\
\text { Temp } \\
\circ F\end{array}$ & $\begin{array}{c}\text { Bed } \\
\text { Temperature } \\
\text { Data (G) }\end{array}$ & Case \\
\hline 60 & 35 & $(E)$ & (F) & (F) & & & & Normal \\
\hline 62 & 245 & (E) & (F) & (F) & & & & Surge \\
\hline 120 (B) & 35 & (E) & (F) & (F) & & & & Normal \\
\hline $123(\mathrm{~B})$ & 245 & (E) & $(F)^{\circ}$ & (F) & & & & Surge \\
\hline $180(C)$ & $\mathbf{0}$ & (E) & (F) & (F) & & & & Normal \\
\hline 51.2 (D) & 35 & (E) & (F) & (F) & & & & Normal \\
\hline $51.2(D)$ & 245 & (E) & (F) & $(F)$ & & & & Surge \\
\hline
\end{tabular}

* Please pravide the minimum and maximum recommended superficial velocity.

A) Reference conditions are SBS outlet conditions unless indicated otherwise.

B) HEME may be bypassed to attain the flow requested.

C) Room air will be drawn directly into the SBS rather than drawing air through the melter.

D) Reference conditions for this case are to be $14.7 \mathrm{psia}$ and $60^{\circ} \mathrm{F}$. This flow is the Fluor requested superficial velocity of $0.26 \mathrm{~m} / \mathrm{s}$.

E) Differential pressure will be measured between the inlet line (just above the SBS lid) and the plenum space of the SBS.

F) DF measurements require feeding of the melter. Data will be collected at the nominal off-gas operating conditions. Fluor is examining the need for DF factors at multiple flowrates during the melter test.

G) Temperatures will be collected from 27 thermocouples within the bed. SBS target temperature is $125^{\circ} \mathrm{F}$. Pat Early at Fluor will notify PNL of any change to this temperature is required. Surge steam rates will not be required to maintain SBS temperature. 
APPENDIX C: SBS DRAWINGS 


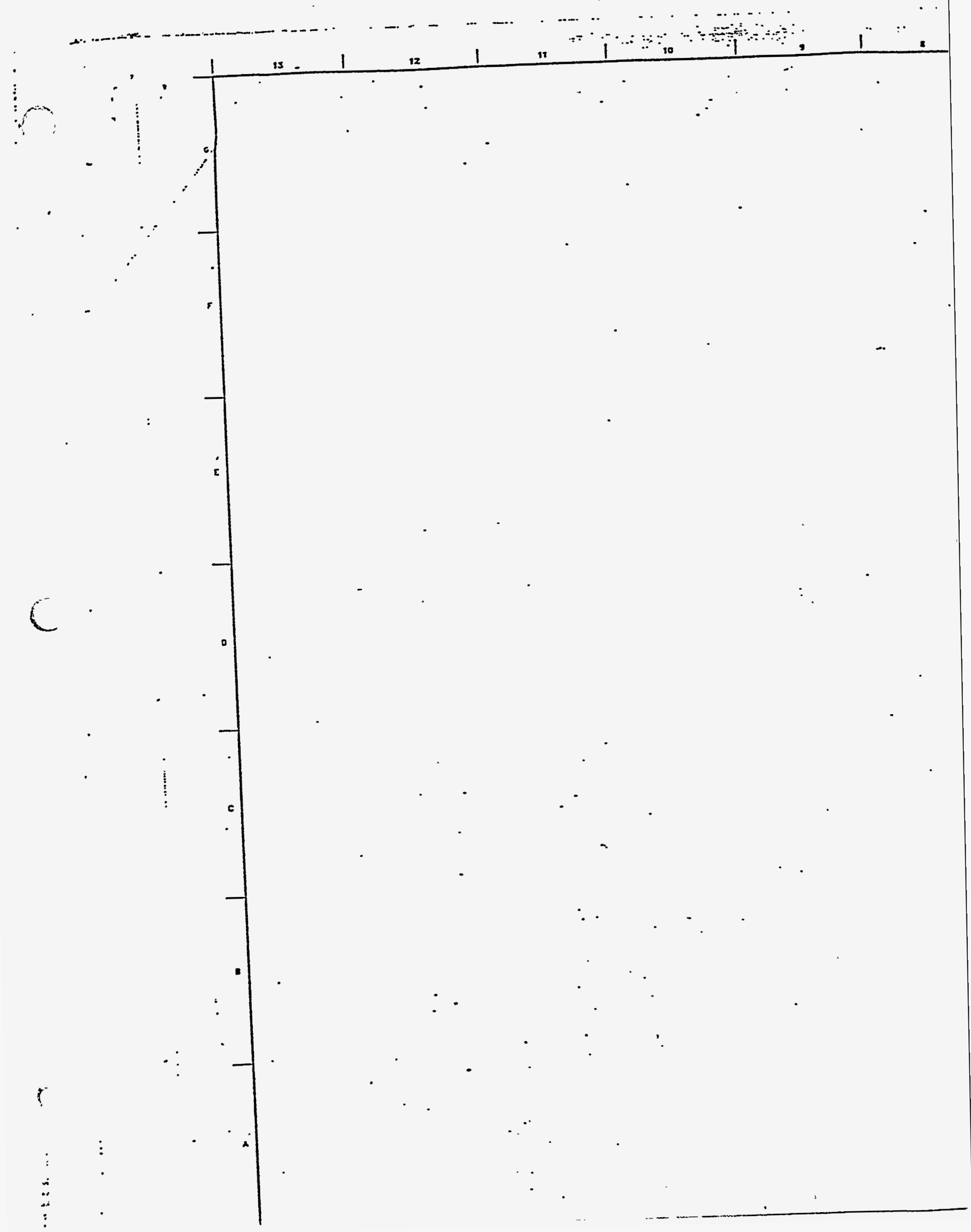




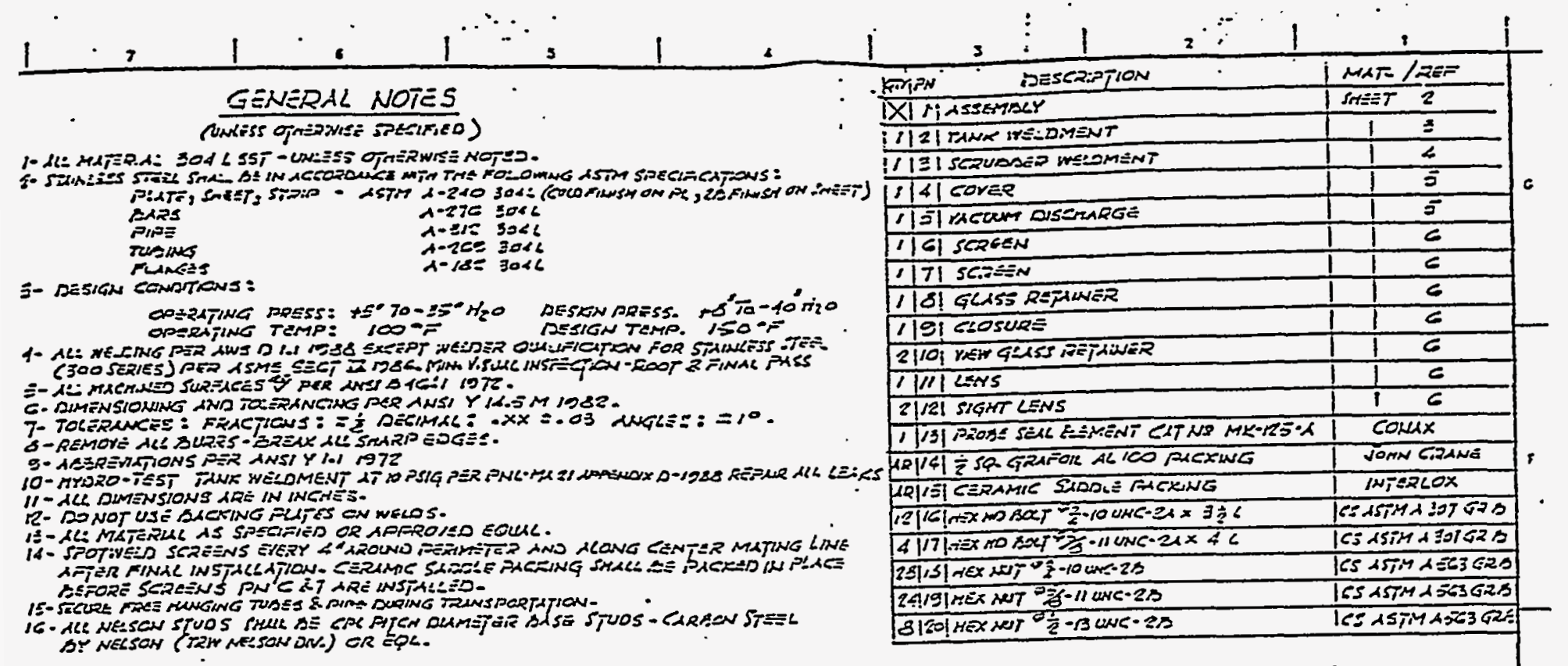

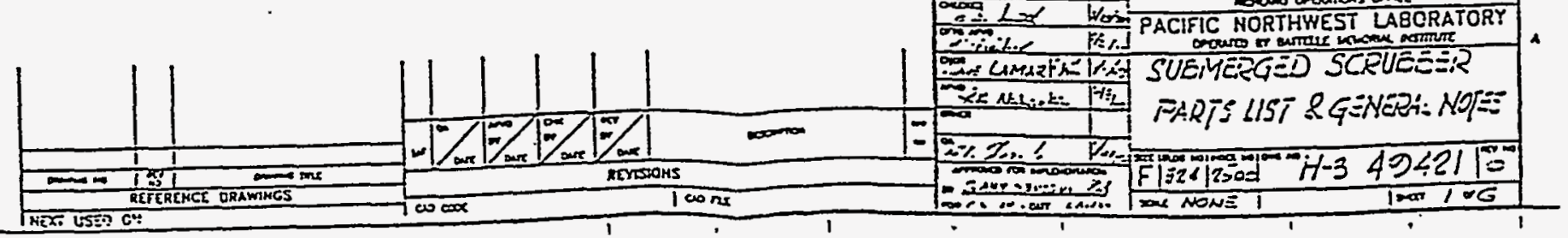




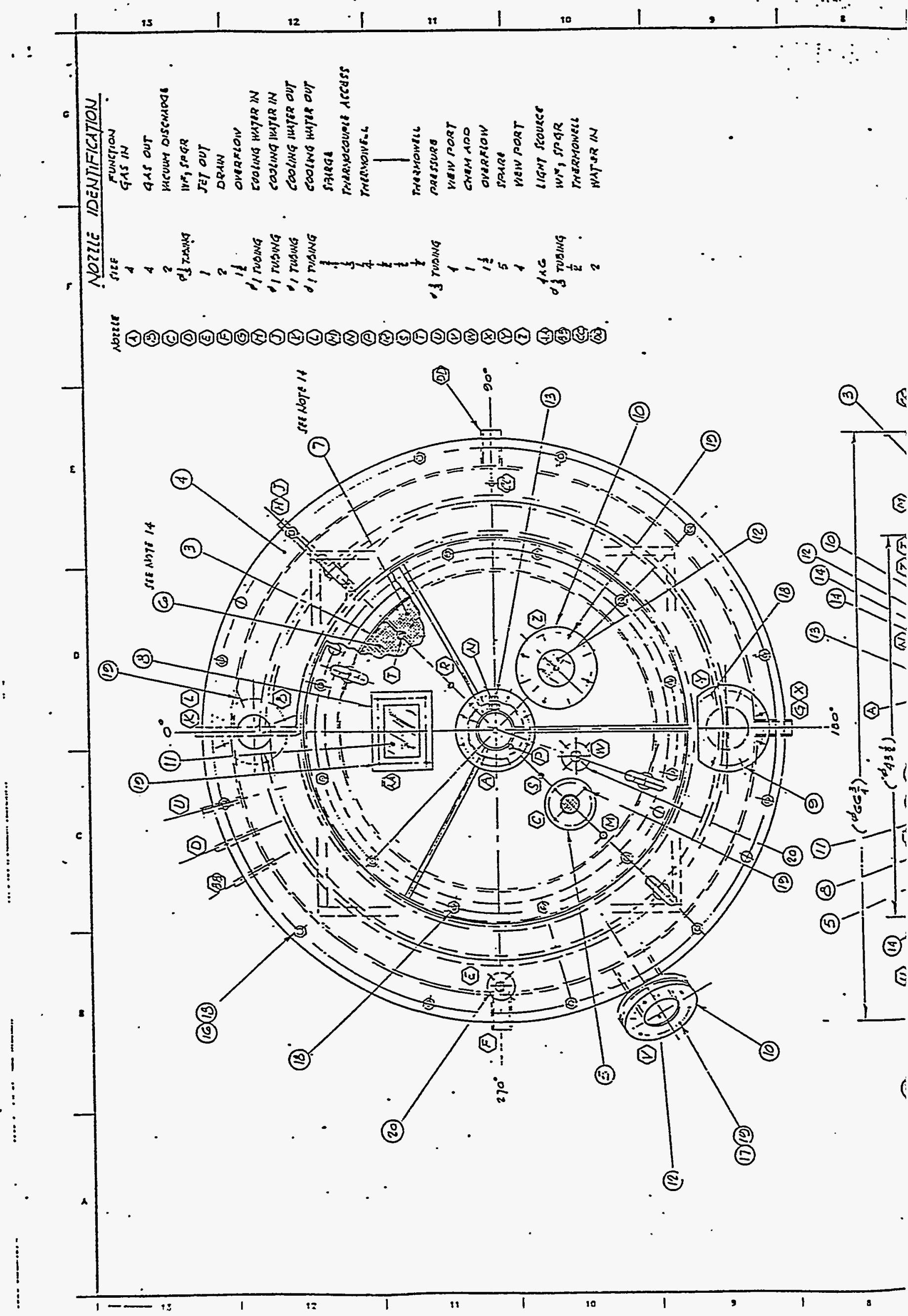




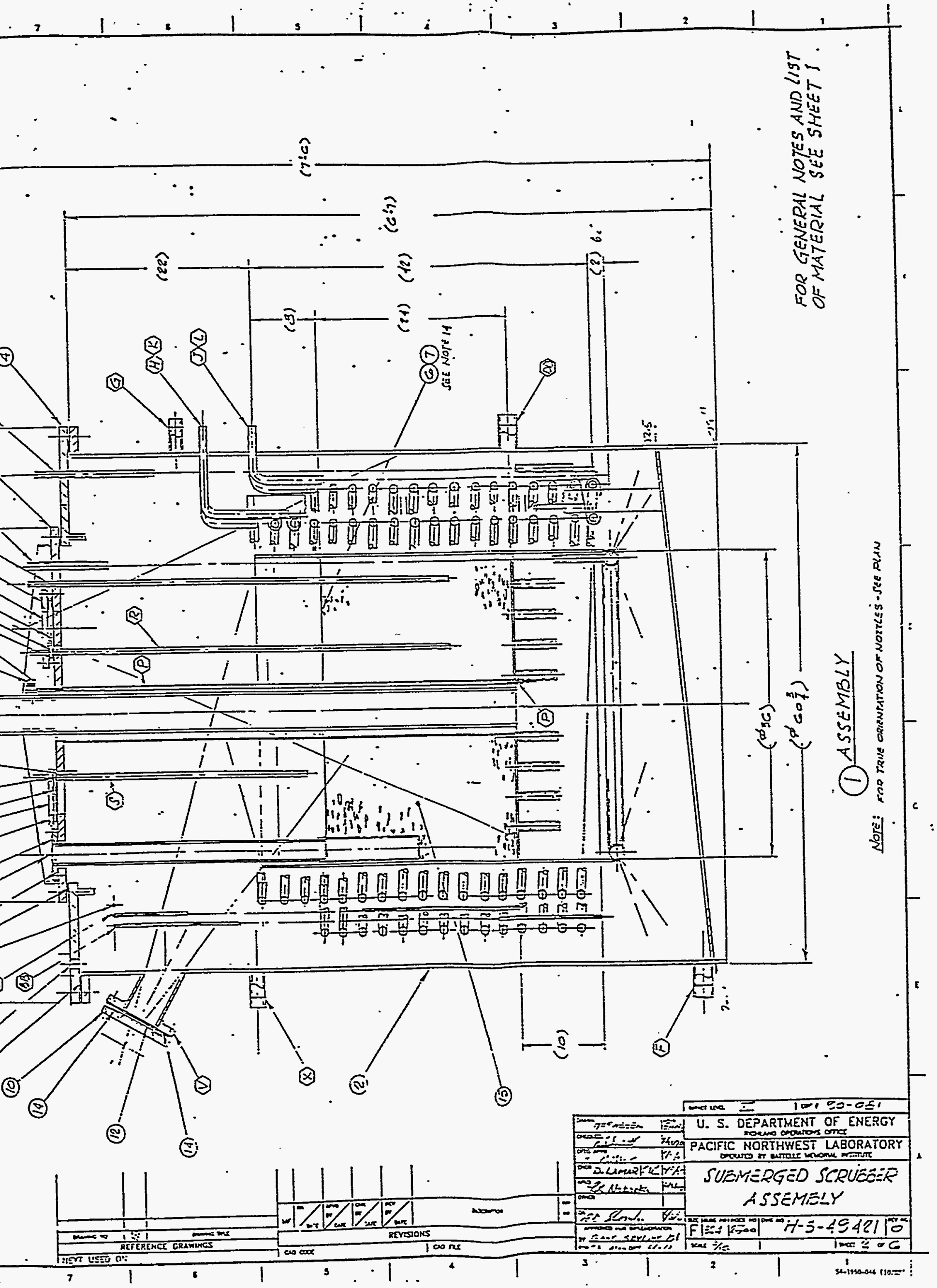




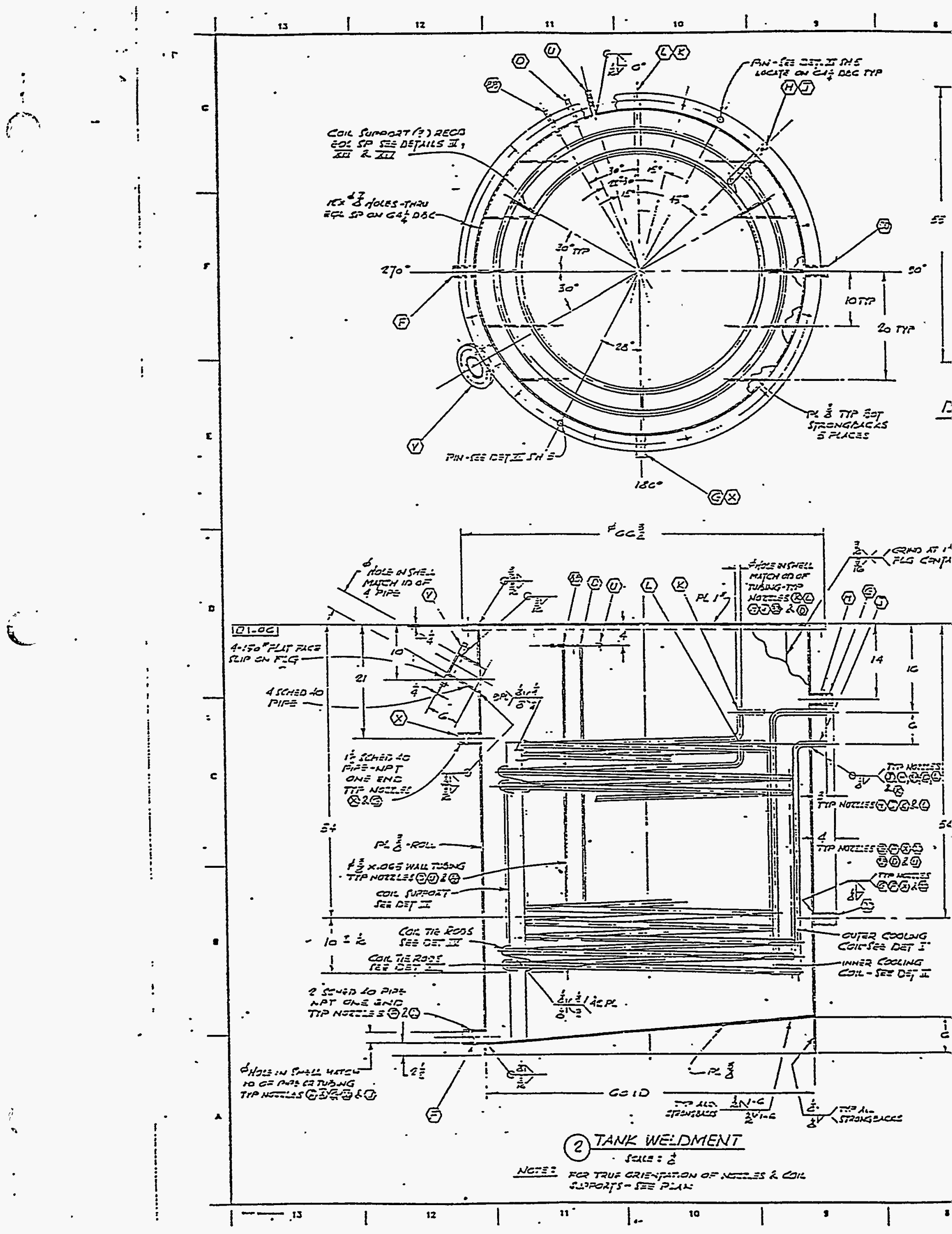




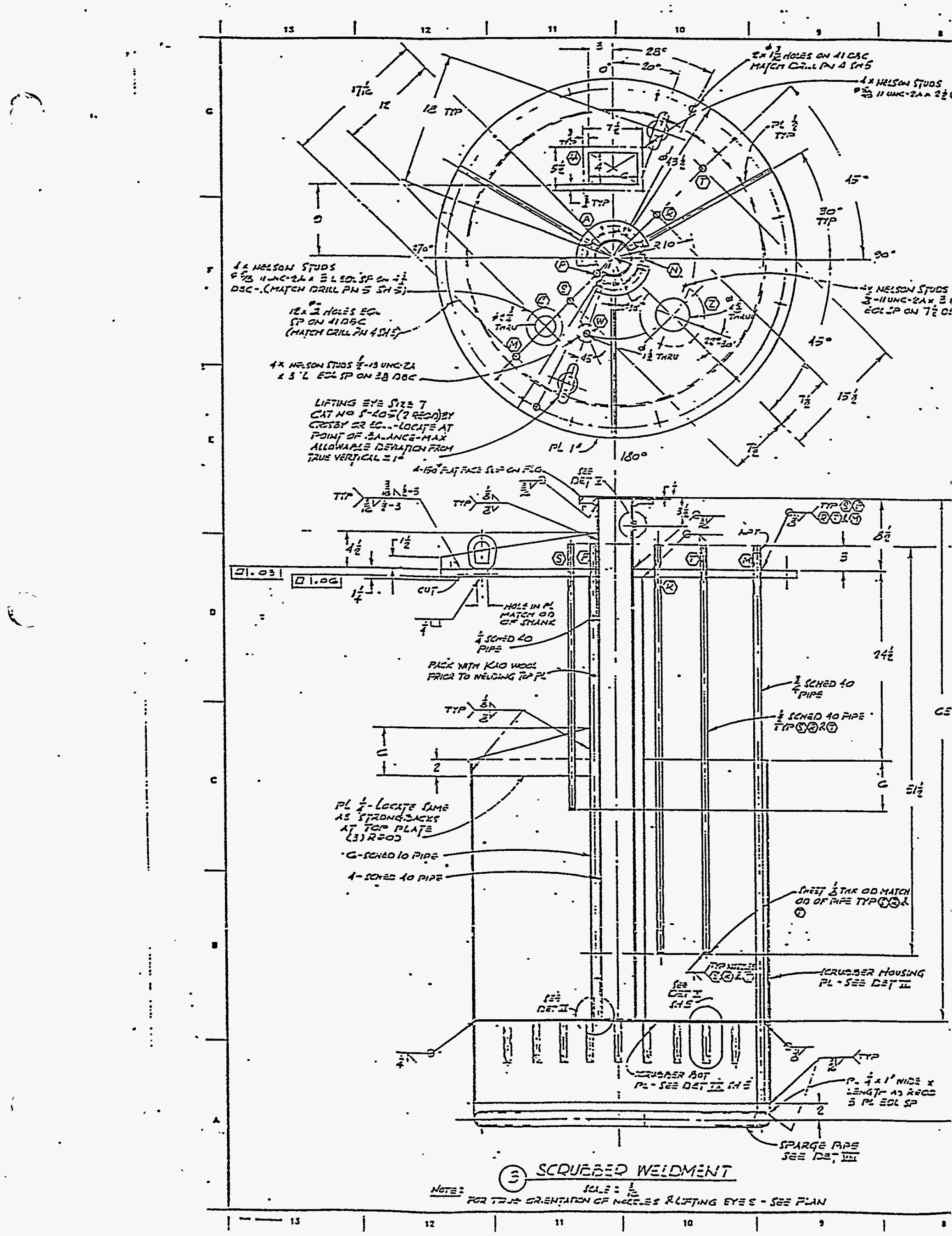




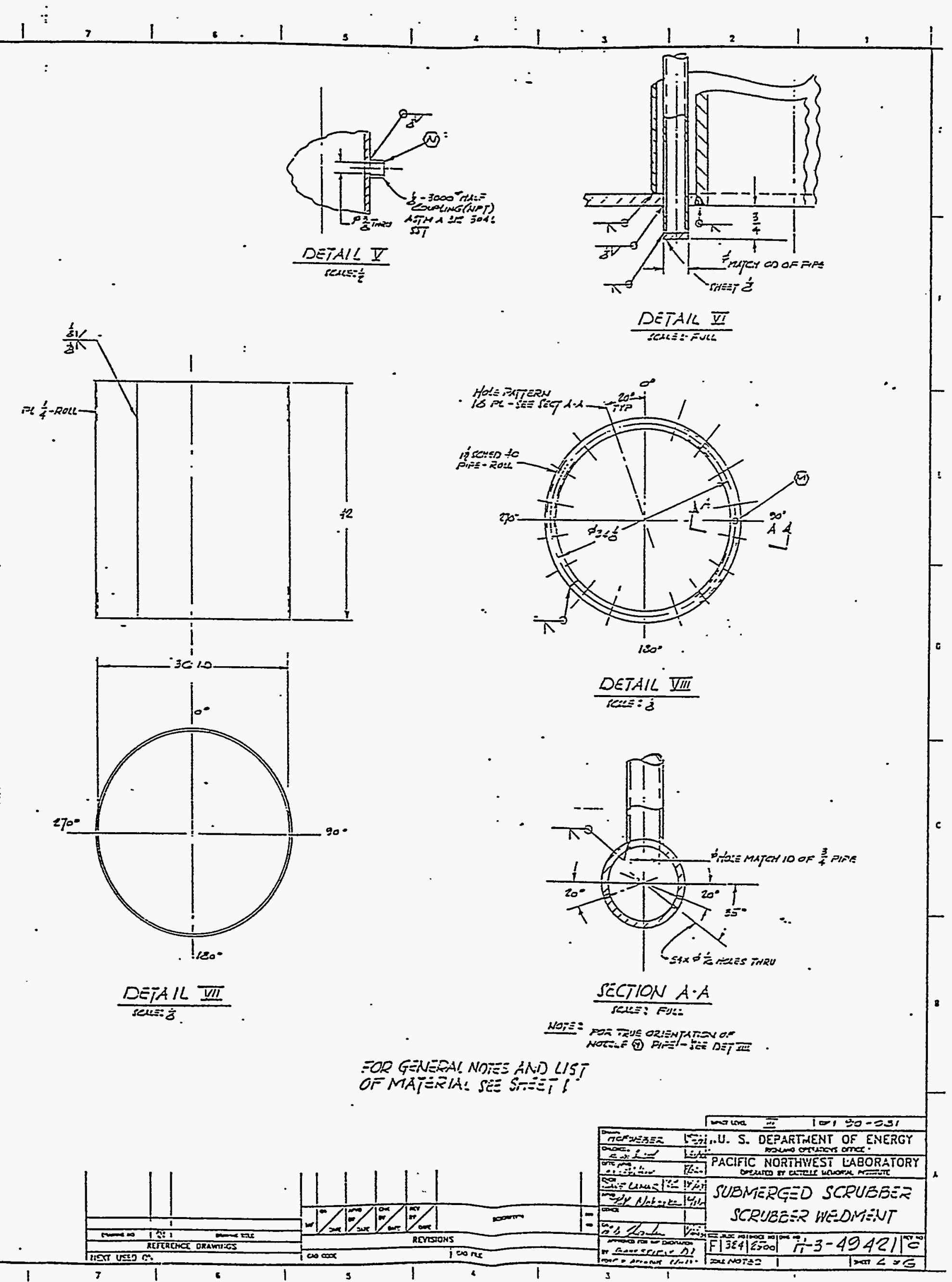




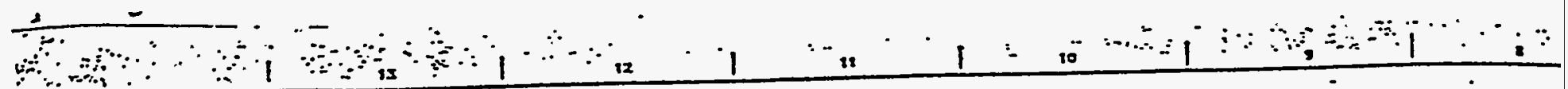
a For revised distribution plate $\because \because \therefore \because \therefore \quad \therefore$ For detarts, see sht 5 a of 6

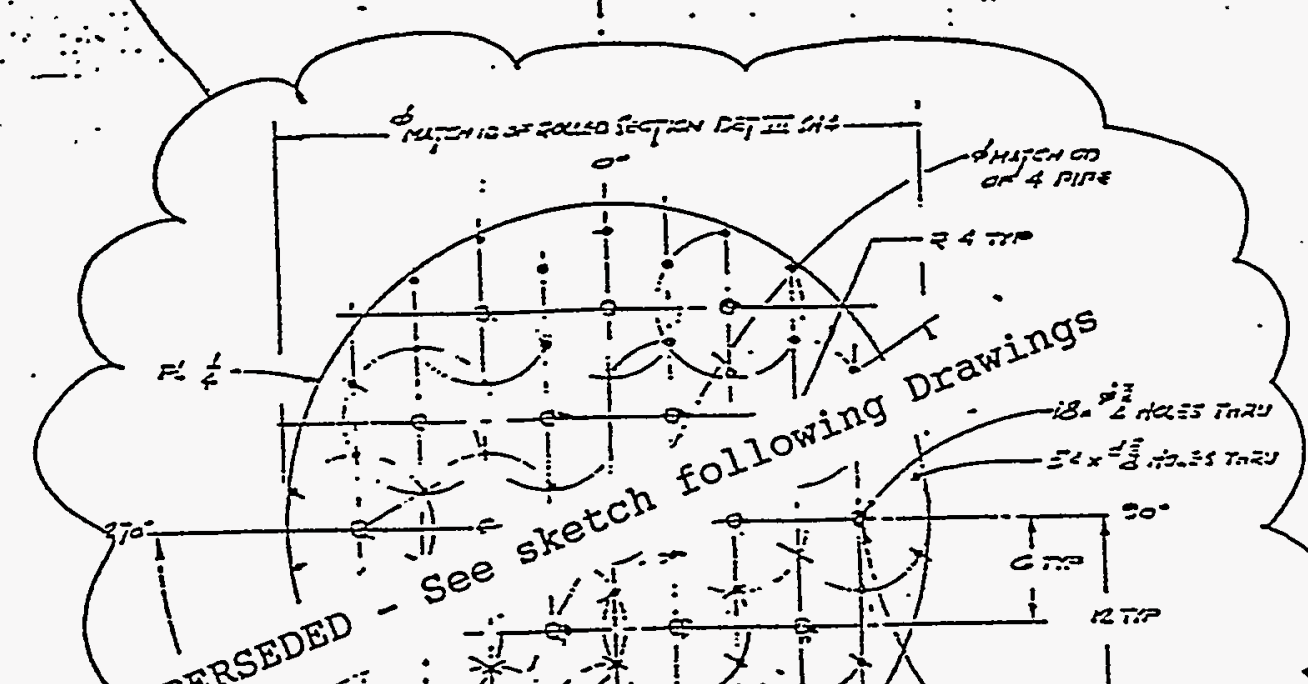

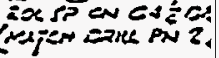
(wixp an

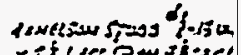

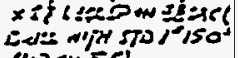

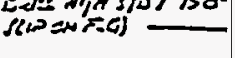

Dif max:

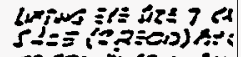

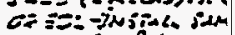
on

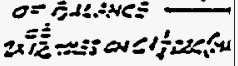
$3 x$ in

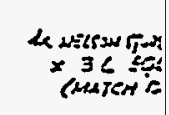
ex:= 言
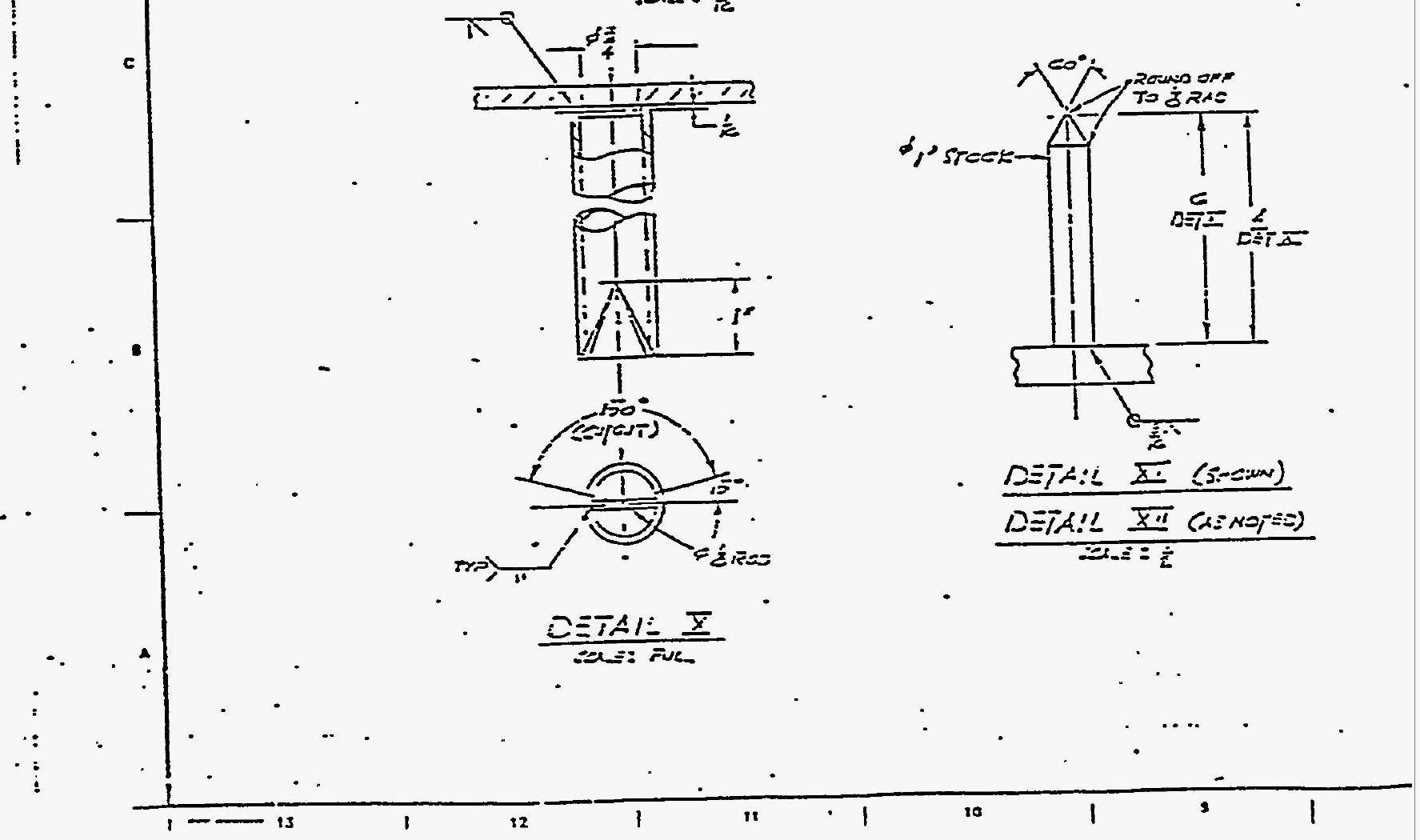

[01.01

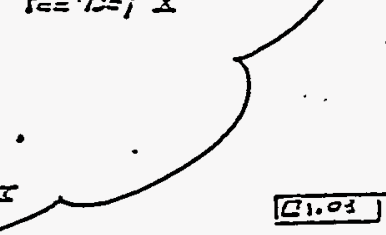


DON'T SAY IT -- Write It!

To: Pat Early

Subject: Clarification on SBS Construction
Date: March 4, 1992

From: Greg Whyatt

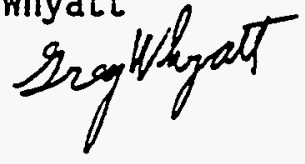

Below is some additional information on the points that we talked about earlier today concerning actual construction of the SBS.

1) The sketch specifies 1,5 in. \#14 BWG tubing (wall thickness 0.083 in.l internal area $1.398 \mathrm{in}^{2}$ ) and allows similar tube to be substituted. The acthal tube used was 1.5 in. $0 D, 0.065$ in. wall with internal area 1.474

2) The cutaway on the tubes is specified to face radially outward.

3) The cutaway reaches one inch from the bottom of the tube and intersects 150 degrees of arc on the bottom edge of the tube.

4) The $1 / 8$ inch rod shown is indicated to be in the top of the tube. . It was originaliy intended to prevent packing from falling out through the tubes. The distribution plate has been covered with a 1/2-inch screen to prevent packing loss and the rods are not included in the current SBS.

If you have any further questions, please call be at 376-0011. 
7:

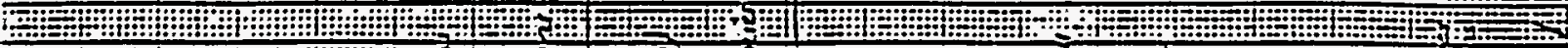

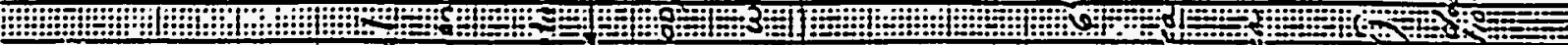

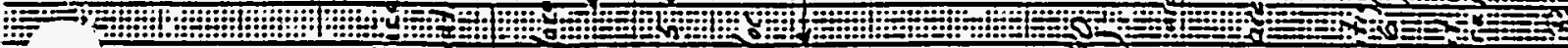

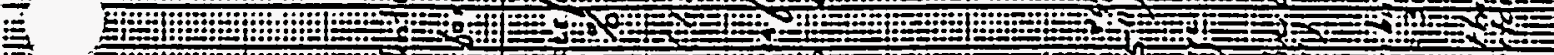

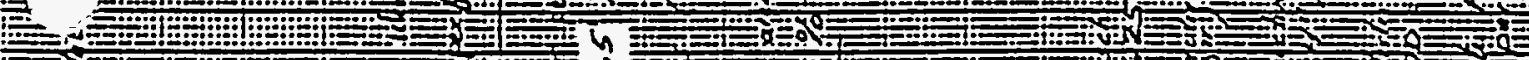

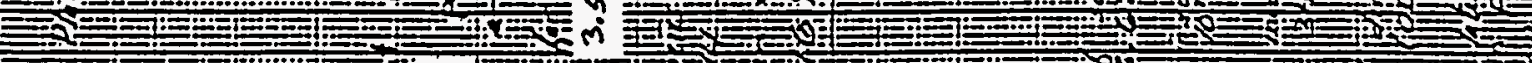
1 1

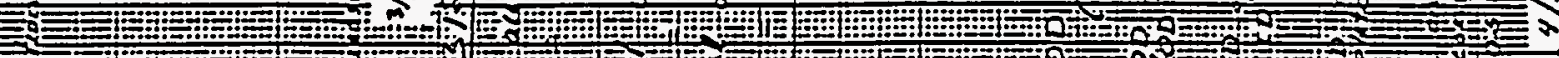

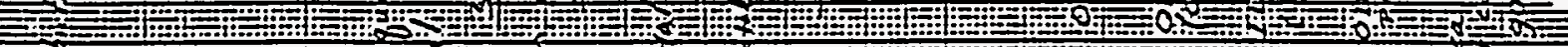
3 =

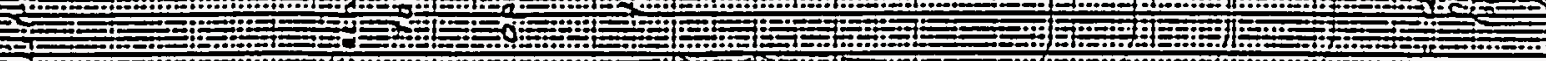

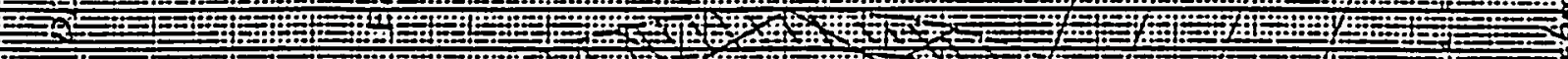
(n)

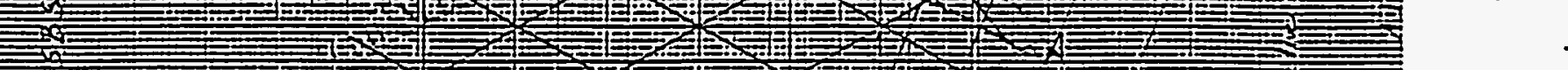

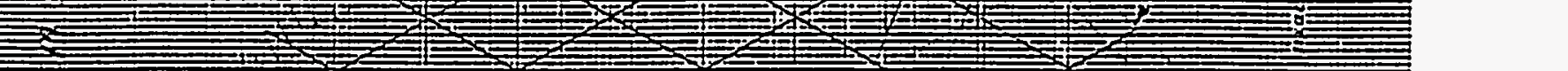

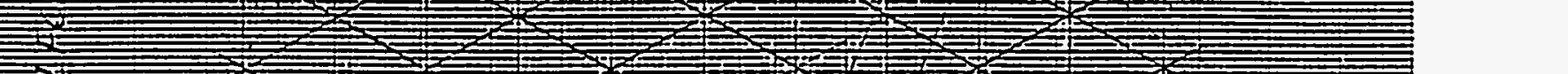
(n) $2 x$ (n) $2 x$ (n) (n) (1) 
$x$

"

r 